\title{
History of the 185-/189-D Thermal Hydraulics Laboratory and Its Effects on Reactor Operations at the Hanford Site
}

M. S. Gerber, PhD

Date Published

September 1994

Prepared for the U.S. Department of Energy Office of Environmental Restoration and Waste Management

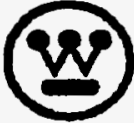




\section{RELEASE AUTHORIZATION}

\section{Document Number: WHC-MR-0465}

History of the 185/189-D Thermal Hydraulics

Document Title: Labortory and its Effects on Reactor Operations, Hanford Site

Release Date: $\quad 9 / 8 / 94$

This document was reviewed following the procedures described in WHC-CM-3-4 and is:

APPROVED FOR PUBLIC RELEASE

***************

WHC Information Release Administration Specialist:

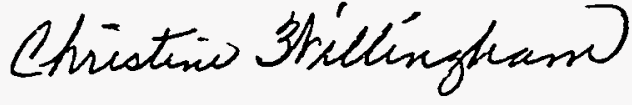

C. Willingham

9/8/94

(Signature)

(Date) 


\section{DISCLAIMER}

This report was prepared as an account of work sponsored by an agency of the United States Government. Neither the United States Government nor any agency thereof, nor any of their employees, make any warranty, express or implied, or assumes any legal liability or responsibility for the accuracy, completeness, or usefulness of any information, apparatus, product, or process disciosed, or represents that its use would not infringe privately owned rights. Reference herein to any specific commercial product, process, or service by trade name, trademark, manufacturer, or otherwise does not necessarily constitute or imply its endorsement, recommendation, or favoring by the United States Government or any agency thereof. The views and opinions of authors expressed herein do not necessarily state or reflect those of the United States Government or any agency thereof. 


\section{DISCLAIMER}

Portions of this document may be illegible in electronic image products. Images are produced from the best available original document. 


\section{CONTENTS}

1.0 ORIGINAL CONSTRUCTION AND USAGE . . . . . . . . . . . . . . . 1

2.0 CMX STUDIES ELIMINATE NEED FOR 185-D FUNCTION . . . . . . . . . . 1

3.0 EARLY GAINS IN KNOWLEDGE END ORIGINAL

189-D BUILDING MISSION ... . . . . . . . . . . . . . . . 4

4.0 CORROSION STUDIES REMAIN IMPORTANT AT EARLY HANFORD $\ldots$. . . . . . . 4

5.0 POWER LEVEL INCREASES RAISE NEED FOR CORROSION INFORMATION .................... . . 4

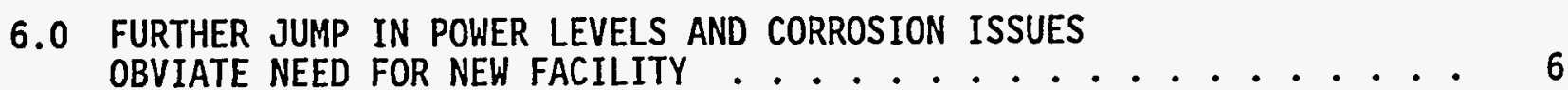

7.0 185-D AND 189-D BUILDINGS CONVERTED

TO FLOW LABORATORY . . . . . . . . . . . . . . . . 6

$8.0185 / 189-D$ EXPERIMENTS LEAD TO HISTORIC CHANGES
IN HANFORD REACTOR OPERATIONS . . . . . . . . . . . . . . . 10

9.0 WATER PROCESS SPECIFICATIONS MODIFIED . . . . . . . . . . . 12

10.0 EXPONENTIAL PHYSICS EXPERIMENTS BROUGHT TO 189-D BUILDING . . . . . 13

11.0 CORROSION, THERMAL HYDRAULICS, AND HEAT TRANSFER

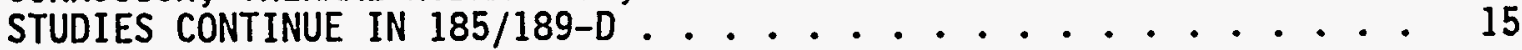

$\begin{array}{ll}12.0 & \text { BOILING CURVE STUDIES LEAD TO FURTHER REVISIONS } \\ \text { IN HANFORD WORKS PROCESS SPECIFICATIONS . . . . . . . . . . . . . . } 18\end{array}$

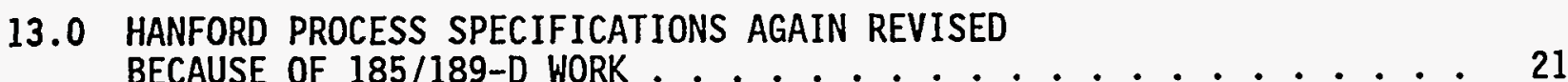

14.0 NEW PRODUCTION REACTOR EXPERIMENTS BEGIN . . . . . . . . . . . 22

15.0 PLUTONIUM RECYCLE TEST REACTOR EXPERIMENTS
ADDED TO $185 / 189-$ D FACILITY . . . . . . . . . . . . . . . . . 24

16.0 FULL-SERVICE THERMAL HYDRAULICS LABORATORY . . . . . . . . . . . 24

17.0 TESTS CONTINUE IN 185/189-D IN SUPPORT OF

EXISTING REACTORS, NEW PRODUCTION REACTOR,

AND PLUTONIUM RECYCLE TEST REACTOR . . . . . . . . . . . 28

18.0 1964 AND 1965 BRING MAJOR CHANGES TO HANFORD SITE

AND REACTOR OPERATIONS .................. 30

19.0 FAST FLUX TEXT FACILITY DEVELOPMENTAL TESTING

BEGINS IN THE $185 / 189-D$ FACILITY . . . . . . . . . . . . 33 
20.0 1970 AND 1971 WITNESS END OF SINGLE-PASS

REACTOR OPERATIONS AT HANFORD . . . . . . . . . . . . 35

21.0 SIMULATIONS IN 185/189-D BUILDING AID IN

N REACTOR REPAIRS IN 1980s . . . . . . . . . . . . . . 38

22.0 REFERENCES . . . . . . . . . . . . . . . . . . 44 44

23.0 BIBLIOGRAPHY ... . . . . . . . . . . . . . . 52 


\section{LIST OF TERMS}

$\begin{array}{ll}\text { AEC } & \text { Atomic Energy Commission } \\ \text { BDF } & \text { Indicates components from B, D, and F Reactors, the oldest } \\ \text { BNWL } & \text { Hanford Site reactors } \\ \text { C-D } & \text { Battelle Northwest Laboratory } \\ \text { dC } & \text { charge-discharge } \\ \text { D\&D } & \text { direct current } \\ \text { DOE } & \text { decontamination and decommissioning } \\ \text { DUN } & \text { U.S. Department of Energy } \\ \text { dUPont } & \text { Douglas United Nuclear Corporation } \\ \text { EBR-II } & \text { E. I. duPont de Nemours and Company } \\ \text { FFTF } & \text { Experimental Breeder Reactor II } \\ \text { HCR } & \text { Fast Flux Test Facility } \\ \text { HEDL } & \text { Horizontal Control Rod } \\ \text { HEW } & \text { Hanford Engineering Development Laboratory } \\ \text { HTLTR } & \text { Hanford Engineer Works } \\ \text { HW } & \text { High-Temperature Lattice Test Reactor } \\ \text { I\&E } & \text { Hanford Works } \\ \text { MIBP } & \text { internally and externally } \\ \text { NPR } & \text { monoisopropylbiphenyl } \\ \text { PCCF } & \text { New Production Reactor } \\ \text { PNL } & \text { Poison Column Control Facility } \\ \text { PRTR } & \text { Pacific Northwest Laboratory } \\ \text { RTD } & \text { Plutonium Recycle Test Reactor } \\ \text { TAI } & \text { resistance temperature detector } \\ \text { TOE } & \text { trip-after-instability } \\ \text { UNI } & \text { time operated efficiency } \\ \text { VSR } & \text { United Nuclear Industries, Inc. } \\ & \text { vertical safety rod }\end{array}$




\section{WHC-MR-0465}

This page intentionally left blank. 
WHC-MR-0465

\section{HISTORY OF THE 185/189-D THERMAL HYDRAULICS LABORATORY \\ AND ITS EFFECTS ON REACTOR OPERATIONS \\ AT THE HANFORD SITE}

\subsection{ORIGINAL CONSTRUCTION AND USAGE}

The 185-D Deaeration Building and the 189-D Refrigeration Building were constructed at the Hanford Engineer Works (HEW), World War II name for the Hanford Site, by the E. I. duPont de Nemours and Company (duPont) during 1943 and 1944. They were completed in late 1944 just before the startup of D Reactor on December 17, 1944. The 185-D Building was 1arge (306 ft long by $48 \mathrm{ft}$ wide by $182 \mathrm{ft} \mathrm{high),} \mathrm{and} \mathrm{it} \mathrm{sat} \mathrm{just} \mathrm{east} \mathrm{of} \mathrm{the} \mathrm{189-D} \mathrm{Building.} \mathrm{It}$ contained ten, four-stage, rubber-lined deaeration units ("towers") mounted verticaliy on steel structures, 20 acid dilution tank pumps, 18 other pumps, 16 chemical storage tanks, a proportioner feed tank, and a one-half ton transfer monorail and hoist. The 189-D facility also was large (307 ft long by $76 \mathrm{ft}$ wide by $53 \mathrm{ft}$ high), and it contained six industrial refrigeration units, six evaporative coolers, seven pumps, as well as various 1 ifts, hoists, and freon tanks. It contained no personnel service facilities, such as rest rooms or lunchrooms.

Both buildings were constructed as part of the influent water cooling system for $D$ Reactor. The original plan called for cooling water to be pumped from the Columbia River at the 181-D River Pump House, purified and treated in the 182-D Reservoir and Pump House and in the 183-D Filter Building, demineralized in the 186-D Demineralization Plant, deaerated in the 185-D Deaeration Plant, and then cooled in the 189-D Refrigeration Building. Water then would flow into the 190-D Process Pump House and be delivered to the front risers of the reactor building itself.

The original purpose of the 185-D facility was to purify reactor process water by removing dissolved gases, especially oxygen. Such "degassification" of the coolant water was obtained by passing it through towers in which a vacuum was maintained via steam jets. Equipment to feed acids, sodium dichromate, and sodium siticate were provided at the towers for corrosion control.

\subsection{STUDIES ELIMINATE NEED FOR 185-D FUNCTION}

However, at the same time that the 185-D Building was being constructed, extensive water treatment and corrosion studies were under way at HEW. A special corrosion study "laboratory" was established in the Hanford Construction Camp in September 1943. Known as the CMX facility (Building 145), the laboratory was located on the bank of the Columbia River about one-quarter mile north of the Chicago, Milwaukee, and St. Paul Rail Depot in the preSite town of Hanford. The CMX assignment was to develop, via experiments with

${ }^{\star}$ Freon is a trademark of E. I. duPont de Nemours and Company. 


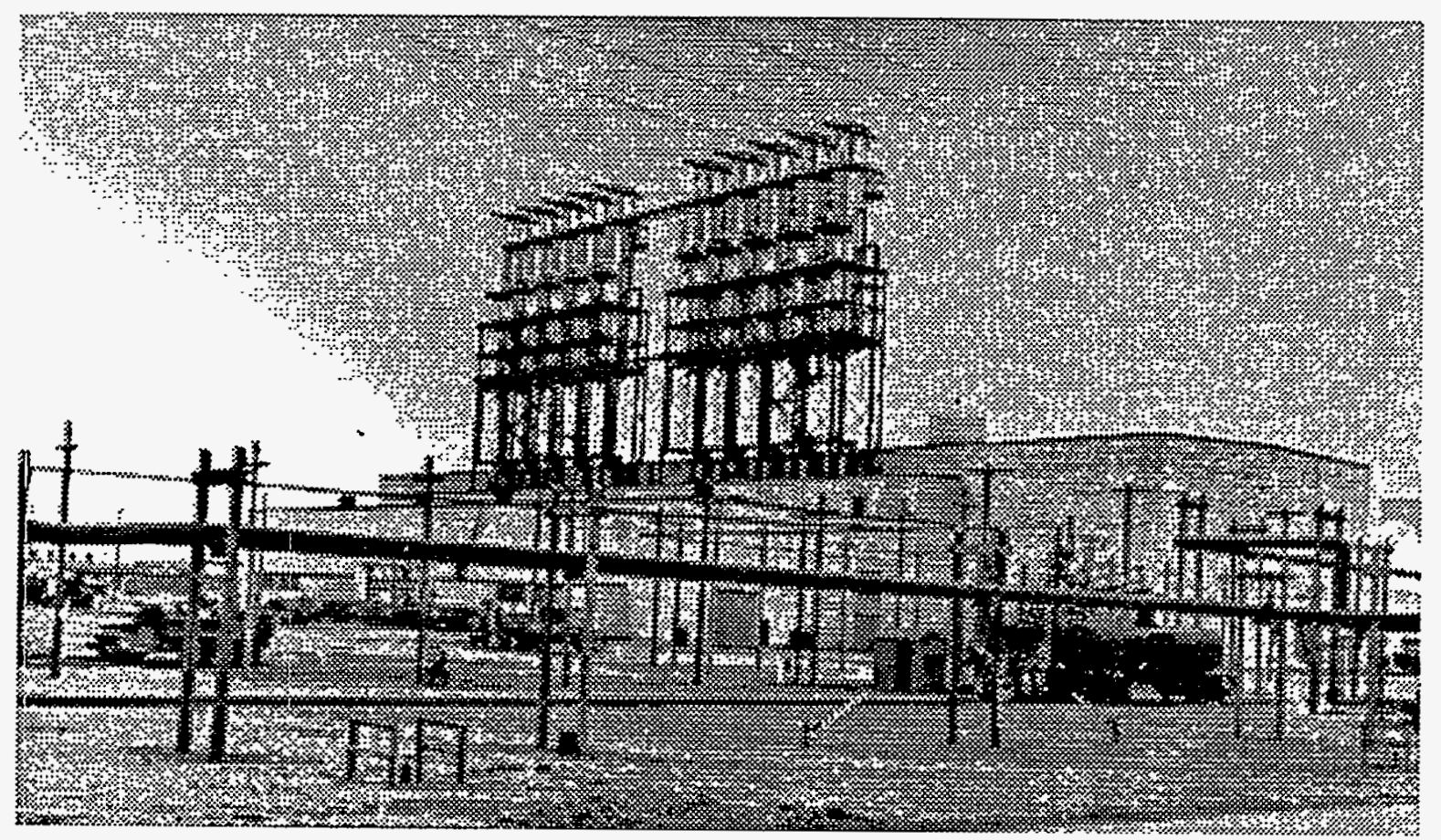

The 185-D/189-D Buildings as they stood new in 1945 .

actual river water, the process treatment standards for reactor influent water. By January 1944, CMX experiments had found film formation on simulated reactor process tubes to be a serious problem, but they also had found no. difference with or without the use of deaerated water. According to duPont: "Therefore, in order to eliminate one variable and obtain a more rapid solution to the film problem...all runs using deaerated or demineralized process water were stopped." In late October 1944, with the HEW process water standards in place, the CMX operation was shut down. The huge deaeration equipment installed in the 185-D Building, as well as the demineralization equipment in the 186-D Building, was never used. Both sodium silicate and sodium dichromate were fed into the reactor coolant at the 183 filtration plants. ${ }^{3}$

The original purpose of the 189-D structure was to deliver chilled water to the central process tubes of $D$ Reactor (those that were expected to become the hottest as a result of the high neutron flux in the center of the reactor). It was thought that such refrigeration would be needed during the summer months (when river temperatures were higher), to ensure that the overal1 bulk outlet operating 1 imit of $65{ }^{\circ} \mathrm{C}$ for effluent water (after passage through the operating reactor) would not be exceeded. In practice, refrigeration was effected for half of the 30,000-gal/minute stream of D Reactor process water. The 15,000-gal/minute flow that was to be refrigerated was valved through the 189-D Building, and then directed to the two center process water storage tanks ("clearwells") of the 190-D Building. Refrigeration was begun in the 189-D Building on Aprif 20, 1945, and discontinued on October 8 . It was resumed on May 6, 1946, but the date that it was discontinued is unknown." 

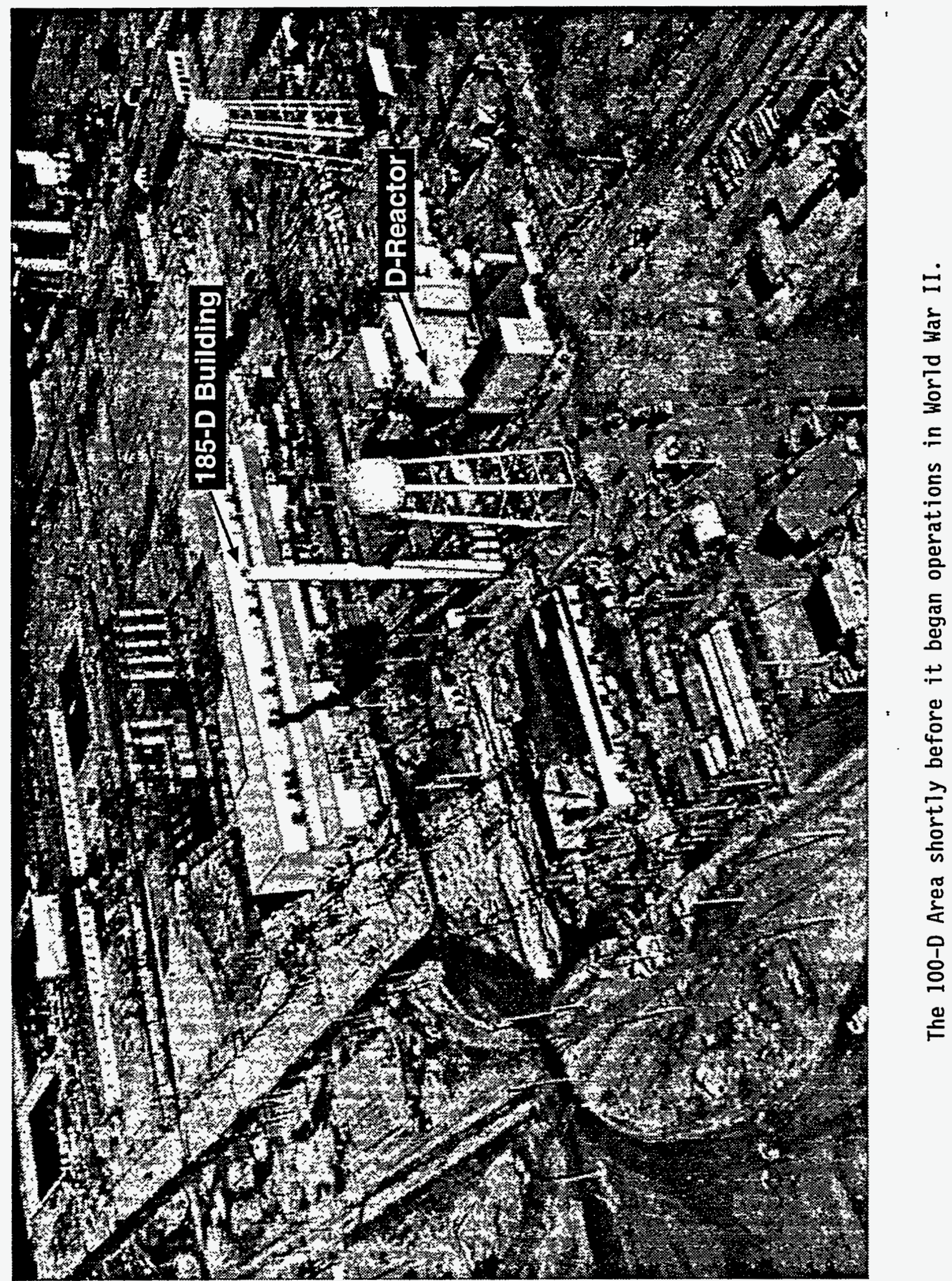


\subsection{EARLY GAINS IN KNOWLEDGE END ORIGINAL 189-D BUILDING MISSION}

Over the years between 1946 and 1951, a great number of changes occurred in reactor operations at the Hanford Works (HW), the Atomic Energy Commission's (AEC's) name for the Hanford Site from 1947 to 1973. One early effort was directed at "flattening" the pronounced cosine curve that existed in the neutron flux (front to rear and side to side) within each "pile" (an early term for a reactor). This curve was produced when the earliest reactor operators distributed "poisons" (neutron-absorbing materials) in a uniform pattern throughout the reactor lattice. Such a distribution was undesirable because it meant that only the uranium fuel elements in the central process tubes of the reactor attained maximum or optimum irradiation, while the uranium in the "fringe" (noncentrally located) tubes received suboptimal irradiation. Additionaliy, the central tubes became the hottest, while the rest of the reactor remained cooler. These temperature gradients caused graphite expansion in the centers of the reactor, a situation that worried Hanford scientists because it contributed to deformation of the graphite stack. Shortly after the end of World War II, experiments were undertaken that varied the poison patterns and achieved a "flatter" curve or uniform neutron flux. This new technique and knowledge led to the discontinuation of refrigeration of the cooling water at $\mathrm{HW} .^{5}$

\subsection{CORROSION STUDIES REMAIN IMPORTANT AT EARLY HANFORD}

Corrosion of the aluminum process tubes and the aluminum-silicon jacketing ("cladding") of the uranium fuel elements in the Hanford reactors remained a problem despite the best efforts of the CMX to develop adequate water treatment methods. Process tube films, composed of various metallic oxides and other corrosion products, became the object of intense study by the "Water, Corrosion, and Engineering" group within the 100 Areas laboratory organization in 1945, after just a few months of reactor operations. The films decreased the ability of the process water to contact and cool the fuel elements, thus causing heat buildup within the reactors, and they allowed corrosion buildup, thus shortening the life of process tubes. ${ }^{6}$

\subsection{POWER LEVEL INCREASES RAISE NEED FOR CORROSION INFORMATION}

Shortly after World War II ended, corrosion studies heightened as Hanford scientists embarked on very preliminary tests to increase the power levels of the reactors. They knew that as power levels rose the higher water temperatures and the increased volumes of cooling water through the process tubes would aggravate corrosion. The power level of D Reactor was increased to $275 \mathrm{MW}$ in December 1945, $25 \mathrm{MW}$ above its design capacity. ${ }^{7}$ Although there was acute interest in pursuing the experiments in increased power levels, the trials were abandoned after just one month because of restructuring in the 
federal management organizations for the Hanford Site and a change in the Site contractor in 1946. The great expansion of the production capacity and facilities of the Hanford Site that occurred during 1947 and 1948 again delayed extensive power level tests, but basic research in corrosion and into the factors that affected heat transfer and cooling capacity within process tubes continued. 8

By January 1946, a "flow Taboratory" at F Reactor, left in partially completed "standby condition" since World War II, was conducting tests to measure the curvature or "bowing" of process tubes and of the vertical "thimbles" (aluminum linings) in the vertical safety rod (VSR) channels of the reactor. In the summer of 1947, an old flow laboratory at D Reactor, which had stopped operations in March 1945, was being refurbished and expanded. $A$ "hot" facility (i.e., one using radioactive substances), the 105-D Flow Laboratory, was located in the riser room in the 105-D Building (the D Reactor building itself). The new test equipment consisted of a mock-up of a reactor process tube fed by irradiated water from the rear face of the reactor and discharged via another special line at the discharge face. It also had a "cold side" (nonradioactive), wherein tests could be run to duplicate flow conditions and temperatures in process tubes without the factor of

radioactivity. For these tests, process water was piped from the valve pit at the front face of 105-D Building.

The first experiments in the 105-D Flow Laboratory measured corrosion in various gasket materials that connected the Van Stone flanges (flared openings on the ends of the process tubes) with the gun barrels (carbon-steel sieeves that supported the ends of the process tubes where they passed through the reactor shields). Other early tests measured "chattering" (up and down movement, a1so known as "fluttering") of fuel elements of various diameters within process tubes. ${ }^{10}$ At the same time, pressure drop tests and trials involving spacers (simulated fuel elements not containing uranium) of varying diameters and densities were conducted in the 105-F Flow Laboratory."

The 105-F and the 105-D Flow Laboratories continued to operate throughout the period of 1948 to 1951, conducting varied experiments with anodized coatings for reactor process tubes, nozzle assemblies, galvanic corrosion, and other issues related to the water cooling of the Hanford reactors.

Because galvanic corrosion was such an important issue, smalt vessels (known as "cups") containing water of different $\mathrm{pH}$ levels and treated with different levels of process chemicals, were placed in the 105-D Flow Laboratory. Then metaliic coupons (short test pieces) were placed in the solution, and electric current was passed through them. These experiments earned the 105-D Laboratory the nickname of "Flow Cup Lab." It also sometimes was known as the "Corrosion Lab."

In 7ate 1948, a heat exchanger was added to this 1aboratory to provide a source of heated process water for the flow cup tests, and by December 1949, a total of 353 flow cups were available for studies. In March 1949, a process tube with a lucite ${ }^{\star \star}$ window insert was installed in the 105-D Flow Laboratory to study fuel element fluttering within the tube. ${ }^{12}$

\footnotetext{
"Lucite is a trademark of E. I. duPont de Nemours and Company.
} 


\subsection{FURTHER JUMP IN POHER LEVELS AND CORROSION ISSUES OBVIATE NEED FOR NEW FACILITY}

The need for a thorough understanding of corrosion issues at the Hanford Site increased dramatically in the 1950 to 1951 period. In the spring of 1949, the long-delayed experiments in increasing the power levels of Hanford's reactors were resumed. That February, the power level at $D$ Reactor was raised to $275 \mathrm{MW}$ for the first time since December 1945. An incremental test program ensued that brought the operating power level of B Reactor to $340 \mathrm{MW}$ by mid-1950 and $H$ Pile to $470 \mathrm{MW}$ by December. That same year, trials were authorized for the 600-MW level, and Hanford scientists began conducting in-depth design reviews to determine the equipment changes that would be necessary for such operations. ${ }^{13}$

One of the most crucial aspects of safe operation at higher power levels, they realized, was to maximize and improve the coolant water delivery systems. Such maximization could not come simply from installing larger pumps in the 190 Buildings, although certainly this would have to be done. If more throughput of water simply led to accelerated corrosion and shortened reactor life, then little would have been gained by the higher power levels. They knew that they had much to learn about pressure drop, improved valves, nozzles, the connectors between the process tubes and the front crossheaders, the corrosion properties of different metals and alloys, chattering and "cocking" (misalignment) of fuel elements within the process tubes, and many other aspects of heat transfer. In December 1950, assessing barriers to higher power levels, Site scientists observed: "Pressure, flow and water quality... are the factors which determine the [power] limits based on the possibility of vapor binding, corrosion and film formation in the piles...0niy rough estimates [of potential power levels] can be made unti] further information has been obtained." 14

\subsection{5-D AND 189-D BUILDINGS CONVERTED TO FLOW LABORATORY}

Consequently, the original equipment was removed from the 185-D and 189-D Buildings. Part of their common wall was removed, and a new corrosion, heat transfer, and "thermal hydraulics laboratory" was emplaced in the joined structure. As prime operating contractor, General Electric Hanford Company explained in a "guide" to its facilities, "The 189-D Building is now considered to be a single building but is made up of what was originally 185 and 189 [D]." 15

Key developments in 1951, which facilitated the decision to build the facility, included a final analysis that it would be cheaper and more feasible to pump more cooling water through the Hanford reactors than to use a smaller volume of refrigerated water. Additionally, this analys is concluded: "Recent data pointed to the possibility that corrosion may be more affected by slug [fuel element] heat generation than outlet water temperature. For this reason, some revision to outlet water temperature appears likely."16 
Conversion and modifications within the 185/189-D facilities began in Apri1 1951 and were completed that December. Equipment included 60 short process tube mock-ups, several sets of hydrautic heads for these tubes, a 50-kH electrical induction heating coil, a weighed tube corrosion apparatus, "dummy" fuel elements (simulations of uranium fuel elements but made of various other solid metals (e.g., aluminum and magnesium), a 25-ton crane capable of traversing the entire length of the 189-D Building, and stacked graphite blocks to simulate varying deflection slopes for process tube entry.

A Tunch and change area for employees was constructed out of part of the original electrical control room in the facility. At the same time, changes and additions were made to the 105-D Flow Laboratory, and the 105-F Flow Laboratory continued to conduct tests. In mid-1951, an expanded Pile Technology Unit, including a Heat Transfer Group, was formed within the Reactor Section of the newly reorganized Manufacturing Department of the G.E. Hanford Company. The 1703-D Building was built to house the Pile Technology group, so that they could pursue their enlarged program of water studies.

Experiments in the $185 / 189-D$ Building continued throughout the next several years, contributing to the coolant flow information that allowed repeated power level increases in the Hanford reactors. Hork began in January 1952 with a calibration test in the induction heating facility to determine fuel element surface temperatures as a function of power input to the coil and tube cooling water flow rate. Solid aluminum dummy elements, as well as stainless steel dummies clad in aluminum, were used in these tests.

The following month, high temperature corrosion studies, using process water with varied $\mathrm{pH}$ levels, were under way. At the same time, knowledge about how film was formed within the process tubes became even more crucial. A slotted process tube was fabricated and emplaced for film formation and corrosion testing, and examinations of the role colloidal particles from the Columbia River in film formation were begun. Further, "weight loss" experiments were conducted in the weighed tube apparatus (weight loss data being used to determine corrosion rates), and corrosion trials of aluminum pieces coupled to graphite samples and exposed to diverse water temperatures were undertaken.

A large Horizontal Control Rod (HCR) Mock-Up apparatus was constructed and tested during the spring of 1952, and a portion of a C Reactor-type HCR was brought in to undergo galvanic corrosion tests. Installation of Resistance Heating Equipment was completed in May, and testing of fuel element "specimens" fabricated in new and varied ways was begun. In a separate test assembly, an electric furnace was emplaced in the 185/189-D Building, and six pieces of aluminum process tubing from DR Reactor were brought in for metal "creep" trials. The latter test was conducted inside a specially constructed, 4-in. Tead shield. ${ }^{19}$ 


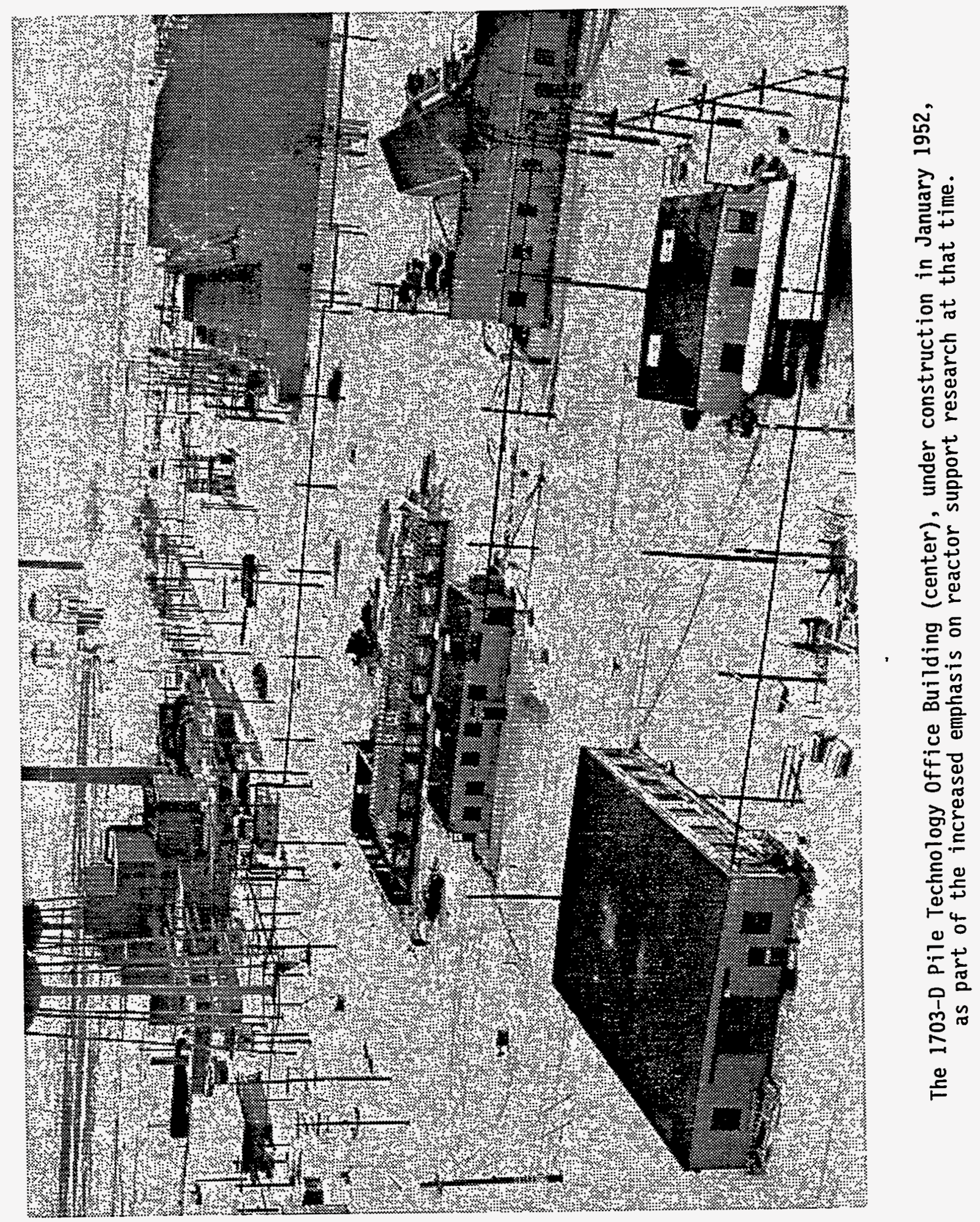




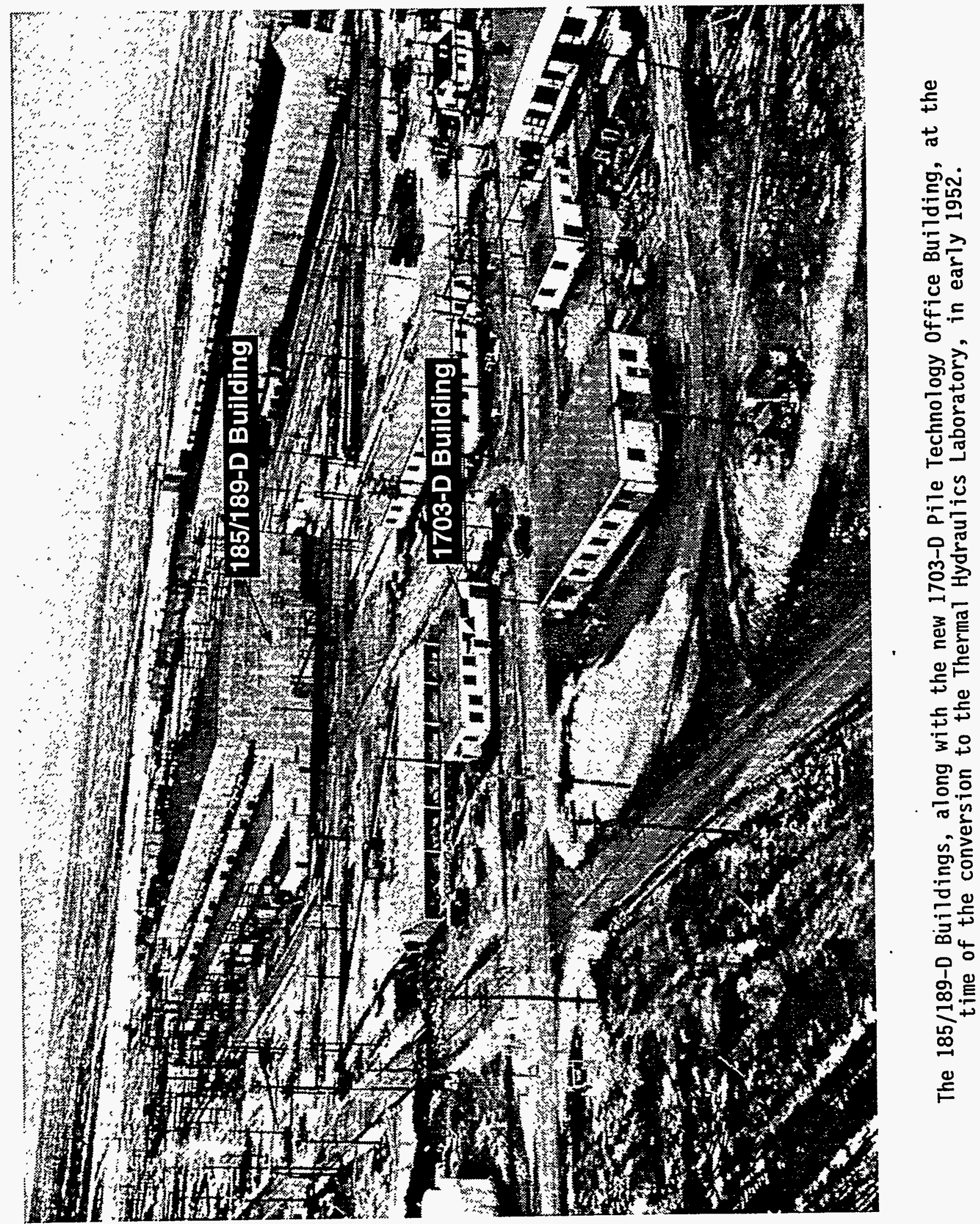




\subsection{5/189-D EXPERIMENTS LEAD TO HISTORIC CHANGES IN HANFORD REACTOR OPERATIONS}

Other important tests conducted during the first year of thermal hydraulics operations in the 185/189-D Building included early trials of a pressurized, charge-discharge ("C-D") machine that was later perfected and used to improve the "time operated efficiency" (TOE) level of all of the Hanford reactors. Further experiments carried out during 1952 evaluated new designs in reactor process tube nozzles, "pigtails" (flexible aluminum connectors between the crossheaders and the nozzles on each process tube), and orifices (flow restriction devices used to maintain pressure within the process tubes). Each of the 7 atter experiments was done using unirradiated materials and did contribute to equipment changes later incorporated into major reactor modification projects that took place between 1956 and $1962 .^{20}$

During early 1953, after a severe "pitting attack" took place within the Hanford reactor process tubes and fuel elements, knowledge concerning corrosion and water treatment chemistry became even more essential to the overall program of increasing power levels. At that time, each reactor needed approximately 200 tube replacements each year, a factor that decreased plutonium production and added to expense and "downtime" (nonoperating time). Site scientists theorized that internal tube corrosion could be caused by "cavitation" (the formation of unstable vapor bubbles caused by higher water temperatures). The collapse of such bubbles ("hammering"), they suspected, caused tiny implosions that blasted at the internal tube surfaces, eventually forming holes. However, they needed empirical proof. ${ }^{21}$

In the 185/189-D Flow Laboratory, short sections of process tubes loaded with dummy fuel elements already were being exposed to various heat generation rates using the induction heating facility. Water flow rate also was diversified. Hot spots on the tubes and fuel elements were induced by placing cocked slugs at several places to reduce coolant flow. Localized boiling, thus, was achieved at the points of contact between the cocked elements and the tube walls. The results of these experiments demonstrated that "no excessive corrosion of the metal takes place due to the 'hammering' of collapsing vapor bubbles."22

A related set of tests was conducted in the 185/189-D Flow Laboratory during 1953, to define the exact conditions of local boiling with respect to metal surface temperature and static water pressure. In this series, cans similar in aluminum composition to the process tubes used in the Hanford reactors, were machined from the inside to reduce the thickness of the walls at various places. The cans then were mounted on inserts, connected to a high direct current (dc) generator, and placed inside glass-walled process tube mock-ups. Water flow was initiated through the mock-ups, and the temperature was increased gradually via the generator. Thermocouples placed on a movable probe then measured exact temperatures as vapor boiling began at the localized hot (thinned) spots. The purpose of these experiments was to determine the probability of localized boiling on fuel element surfaces. ${ }^{23}$ 


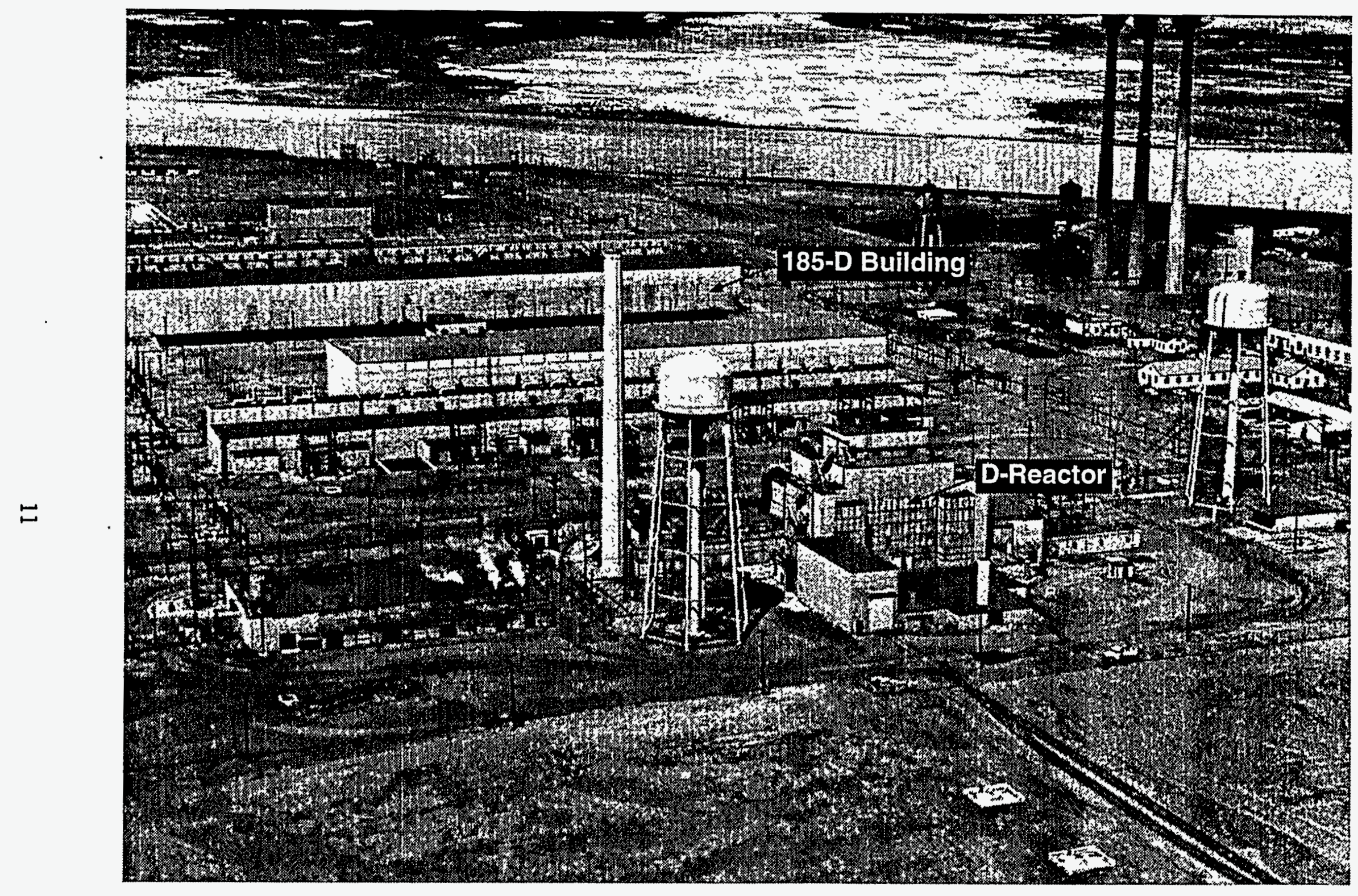

The 185/189-D Thermal Hydraulics Laboratory sits prominently between D Reactor and the Columbia River in this 1953 view. 
At the end of the year and the conclusion of this test series, water quality specialist, N.R. Miller, affirmed that the flow laboratory data were "reliable" and useful "in predicting corrosion trends experienced under in-pile conditions. This fact makes it highly desirable to continue using flow laboratory facilities to the fullest extent possible...because flow laboratory testing is much less costly and hazardous and much more flexible than is in-pile testing." 24

\subsection{WATER PROCESS SPECIFICATIONS MODIFIED}

Throughout 1954, interest in data on "boiling flow" remained high at Hanford, as operators wished to push power levels and temperatures as high as possible under safe conditions. Several tests were conducted in the 185/189-D Flow Laboratory on both ful7-size and short-process tube mock-ups. Size of tube annulus, power or heat levels, uniformity of power distribution along tube 7ength, and header pressure (measured in pounds per square inch gauge [psig]) a11 were varied in these experiments. The information of most interest included the amounts of pressure drop across tube length under diverse conditions and the prediction of "safe operation close to burnout [boiling]." To increase heat generating capacity, additional generating equipment was installed in the building in August of that year.

As a result of the above sets of 1953 and 1954 tests and of 1954 trials in C Reactor, an important change in Hanford's Process Specifications was made in early 1955. The "trip-before-boiling" limit, measured by special gauges on each reactor, was changed to the "trip-before-instability" limit. In other words, the automatic shutdown equipment on the reactors was set to activate ("trip") at higher temperatures than those previously considered safe. In effect, this change meant that nucleate boiling of the coolant within the process tubes was allowed, but that full bulk boiling was not. ${ }^{25}$

Another salient series of experiments carried out in the 185/189-D Flow Laboratory during 1954 was a cooperative program with the Pile Materials Sub-Section, the group responsible for developing and testing new alloys for use in the Hanford reactors. Assessments of tensile strength (flexibility without embrittlement, cracking, or corrosion), elongation, and metallic creep measured against variables (e.g., coolant temperature) were conducted in a "minitube" apparatus in the huge building.

All of this work was directed at identifying process tubes that could withstand higher power and temperature levels than the "2S" aluminum tubes used at Hanford since World War II. As engineering manager, A. T. Taylor, stated: "Increases in production have been gained by increases in tube water flow and outlet water temperature... it can be concluded that a stronger tube in addition to a more corrosion resistant one will be required."26

*2S aluminum was a blend of $99 \%$ aluminum alloyed with small amounts of zinc, manganese, copper, iron, and silicon. Other alloys under consideration in this time period varied the amounts of zinc, manganese, copper, iron, and silicon, while some added chromium and magnesium. 
Still another important 1954 experiment conducted in the 185/189-D Building tested the reliability of a unique design in "resistance bulbs" (flow-sensing devices) in the crossheader fittings that were used in the new K Reactors then being built at the HW. Essential in President Ejsenhower's "New Look" in armaments program, the twin KE and KW Reactors were to operate at temperatures and power levels previously not achieved in any other Hanford pile. Therefore, study and informed predictions of every aspect of their operation was considered mandatory for safety reasons.

The 185/189-D tests evaluated time response in K-type process tube temperature and flow monitors under conditions that simulated a sudden blockage of flow within the tube. The test apparatus consisted of a process tube; an aluminum tube placed inside the process tube to simulate a column of fuel elements; a simulated dummy section of the effluent end pumps, piping, and valving to supply coolant; and associated control devices and monitoring instrumentation. Measurements were taken of both temperature (using a "resistance bulb") and of flow rate (using a rotating flow meter). The resulting data were plotted to demonstrate the expected time response curves for various types of blockage events. As engineer, M. E. Forsman, pointed out: "Attempting to obtain the data from a process tube in the reactor is not oniy expensive but dangerous... [Therefore] the process tube heat transfer test set-up in the 185/189-D Building was used." 2

\subsection{EXPONENTIAL PHYSICS EXPERIMENTS BROUGHT TO 189-D BUILDING}

Meanwhile, during the 1951 to 1954 period, a completely different type of reactor support experiments took place in the 189-D Building. In November 1951, the exponential physics experimental facility at the HW burned to the ground in an unforeseen accident. ${ }^{28}$ At that time, the 326 Pile Technology Building, the new facility planned to hold exponential physics experiments was under construction but not nearly complete. Yet, exponential physics work (known as Secret Project P-12) was considered essential to rapid and competitive reactor development at $H W$, especially to key and timely decisions involving lattice spacing, process channel size, and fuel element size in the new K Reactors:

For these reasons, exponential physics experiments were moved into the 189-D Building in 1ate 1951. As of November 23, the presence of the P-12 work made this laboratory an "exclusion area." Uranium was clad ("canned") in the 108-D Building, a former World War II chemical pump house, and was loaded into 8-ft graphite stacks pierced with process holes of various sizes and lattice configurations and situated in the 189-D Building. Each cube sat on an additional 20-in. graphite base and required 30 to 35 tons of graphite (in total) and 5 to 15 tons of uranium. Small, flat indium foils and some cylindrically mounted indium foils, along with some gold foils, were inserted as the measurement devices. The radioactivity induced in these foils could be measured after each experiment to determine the diffusion length in various lattices, the amount of buckling (neutron leakage from one lattice cell to the next), and other variables. 


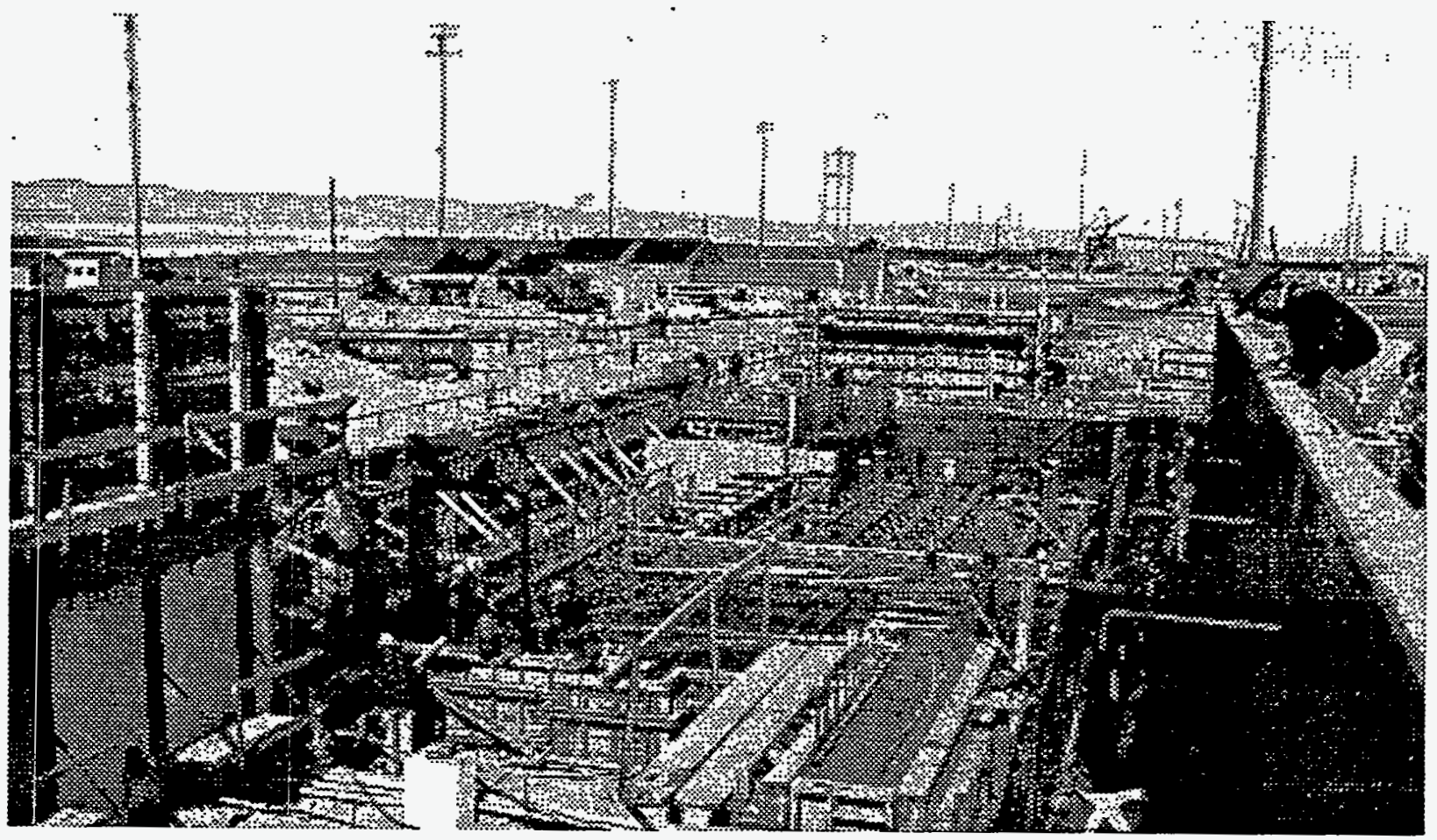

Studies in the 185/189-D Building were important in developing various design and operating criteria for the $K$ Reactors. The KW Reactor is shown here under construction in 1953.

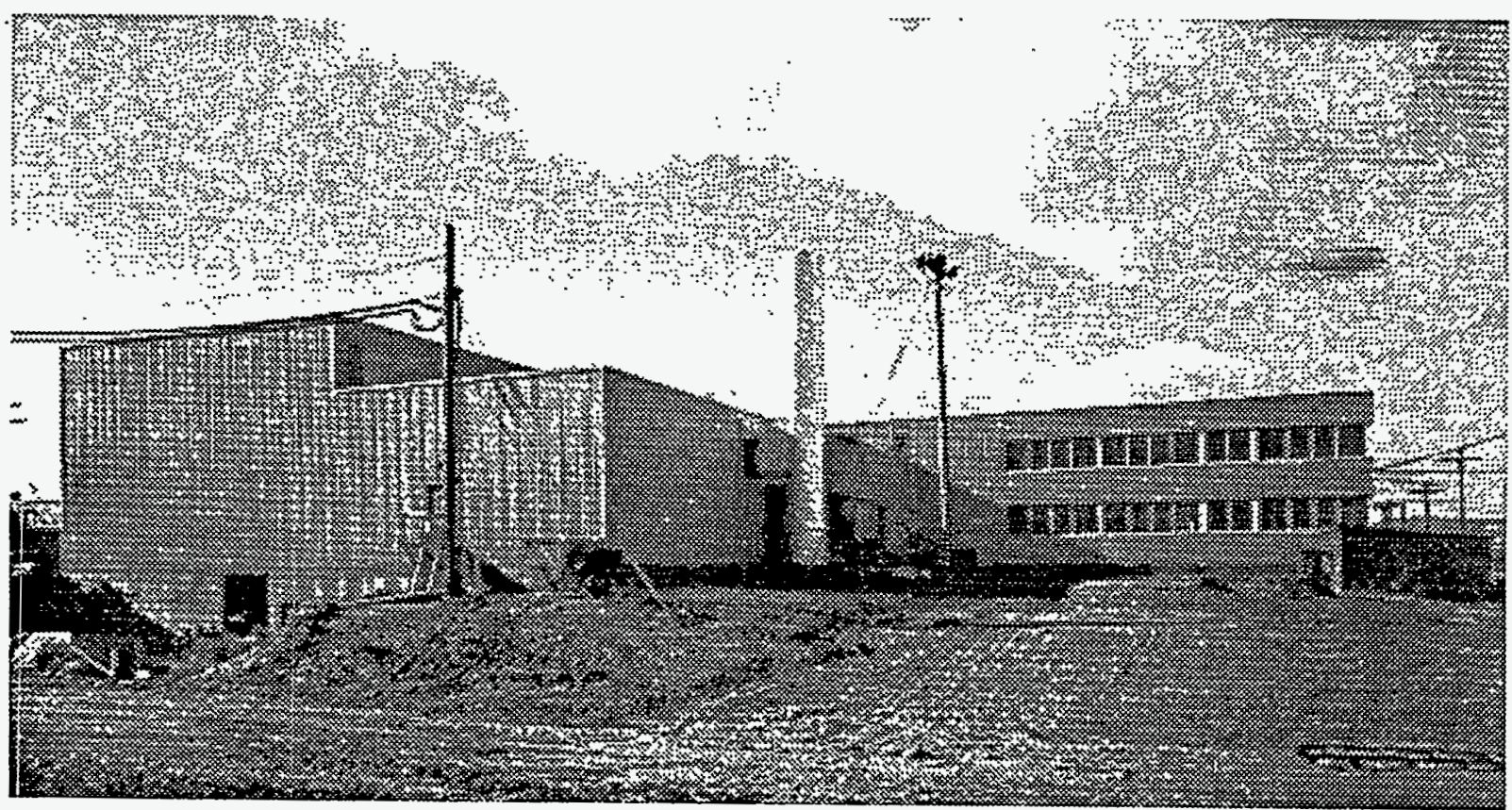

After a brief time in the 185/189-D Building, exponential pile experiments (code named P-12 work) moved into the $326 \mathrm{Pile}$ Technology Building, shown during its construction in 1953. 
Borontrifluoride $\left(\mathrm{BF}_{3}\right)$ neutron-counting devices also were used. In some tests, four radium-beryliium (Ra-Be) neutron sources were placed in a diamond array in the base of the pile, each source having the strength of $6.6 \mathrm{X}$ $10^{6}$ neutrons per second. Some experiments were performed with wet graphite, to determine the effect of this variable on numerous other factors. Shielding was accomplished with lead bricks, built up as walls or sometimes as "caves," to contain the radioactivity.

The exponential physics experiments continued in the 189-D Building throughout 1953, and included, in addition to the activities already mentioned, the following:

- Investigations of the "blackness" (neutron absorbing ability) of various foils

- Tests with hollow fuel elements (both water filled and dry) and with enriched fuel elements ("C" elements, or those containing $4.3 \%{ }^{235} \mathrm{U}$ by weight)

- Resonance escape, the amount of neutron streaming throughout unmachined or damaged graphite within reactors

- Temperature correlations between neutrons and graphite.

In the last quarter of the year, a small exponential pile was built, 48 in. wide and long by 61.9 in. tall. It sat on an additional 19.9-in. graphite base. It was surrounded on al1 sides by a cadmium sheet that acted as a neutron reflector, and four $\mathrm{Ra}-\mathrm{Be}$ neutron sources were placed in a symmetrical diamond array in the base of the pile. The smaller pile was desired to conserve graphite and uranium, but physicists previousiy had been afraid of poor extrapolation ratios between the buckling rate of such a small pile and that of a full-size reactor. However, they found a way to measure the correlation ratio and to compensate for the differences in their calculations.

Many of the experiments conducted in this pile and in the Targer piles in the 189-D Building contributed to a better understanding of the effects of cooling water on the reactivity or buckling in graphite-uranium lattices. The ultimate objective, as with almost all pile-related experiments at HW during that period, was to find ways to safely increase reactor power levels. During the first quarter of 1954, approximately $50 \%$ of the exponential physics equipment, material, and personne? in the 189-D Building moved into the new 326 Building. The remainder of the personnel and equipment completed the move later that year.

\subsection{CORROSION, THERMAL HYDRAULICS, AND HEAT TRANSFER STUDIES CONTINUE IN $185 / 189-D$}

In March 1955, the 105-D Flow Laboratory closed, as its development activities transferired to the new 1706-KE Water Studies Semi-Works. This new facility contained state-of-the-art (in that-era) equipment that rendered the 105-D Laboratory virtually obsolete, especially in the field of recirculation studies. ${ }^{32}$ However, the refitting of the older Hanford Site reactors with recirculating cooling systems was so economically prohibitive that corrosion heat transfer, and other studies on the existing systems remained important. ${ }^{33}$ 


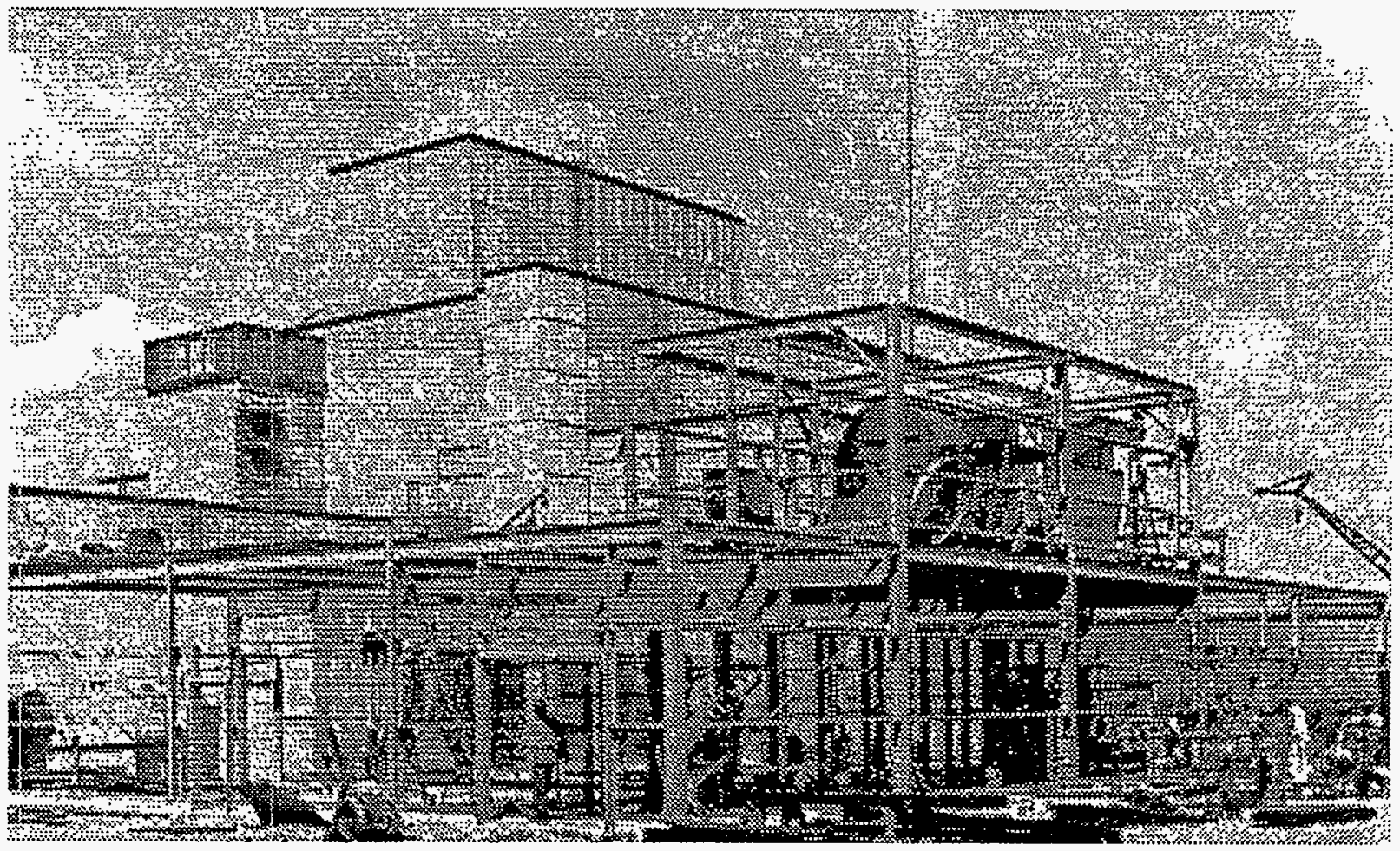

Exterior and interior views of the 1706-KE Coolant Systems Development Laboratory, which opened in 1955.

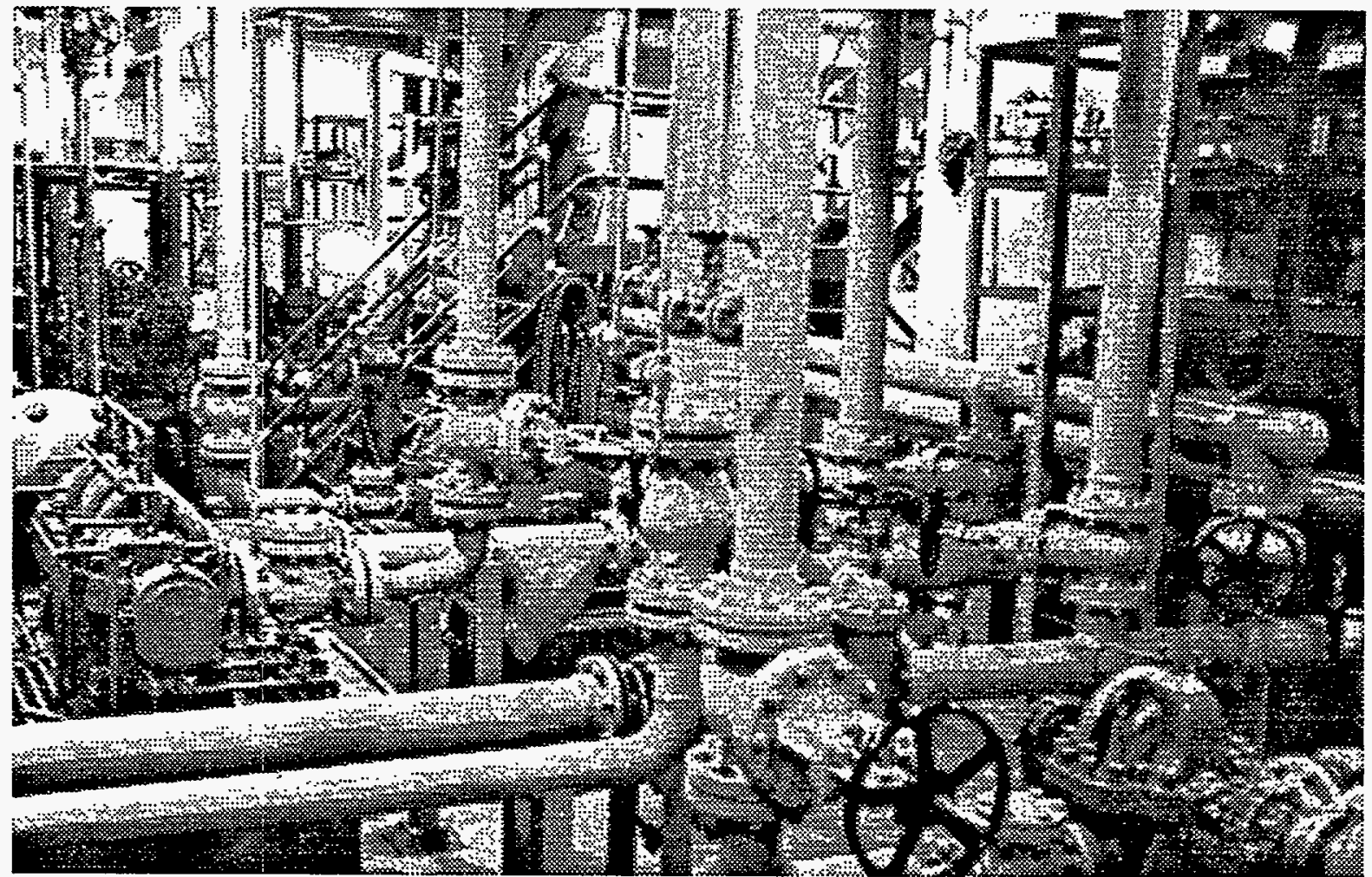




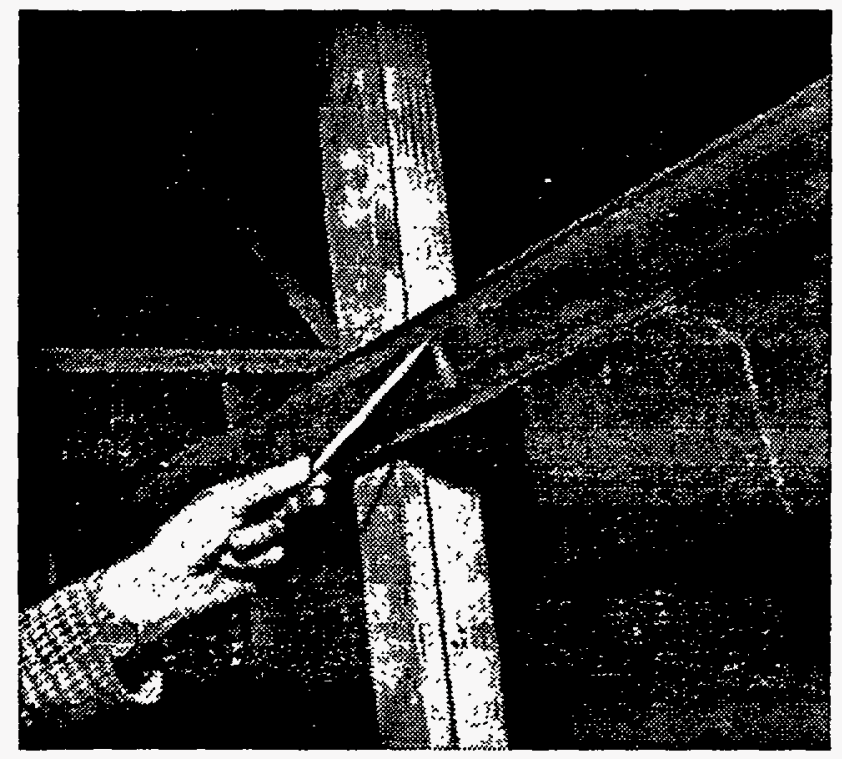

Stress corrosion in a simulated reactor horizontal control rod is examined in the 185/189-0 Building, 1955 (Left).

Throughout 1955, several key experiments were conducted in the 185/189-D Building to investigate coolant variables. One such trial evaluated a new type of wire-reinforced Teflon connector assembly (connecting the inlet water supply with process tubes) for use in the K Reactors. A nine-tube cycling machine, duplicating the inlet-face crossheader and nozzle assemblies used on the K Reactors, was emplaced. Of the nine connectors, six had been predefected by cutting some of the reinforcing wires; twisting, bending, and other rough handling and abuse; and gripping in the jaws of a tensile testing machine. The other three connectors. were undamaged. Then, coolant flow was cycled through all nine connector assemblies at different pressures and temperatures, to simulate a full process tube thermal expansion cycle that took place during $K$ Pile startups and shutdowns. Cavitation tests and other tests also were run.

Other important 1955 tests involved the electrically heated heat transfer mock-up. It was modified during the year to permit investigations of flow, temperature, and pressure conditions during such transient events as power surges, steam loss, plugging of the screens that prevented the entry of solid materials into the reactor tubes, and downstream plugging of tubes. The equipment modifications allowed boiling and burnout tests to be conducted up to 2,000 psi and $1,100 \mathrm{kH}$. Boiling studies continued to be important as reactor operators wanted to determine whether or not the new "trip-beforeinstability" limits indeed represented the furthest outpost on the frontier of safety.

The flow characteristics of various orifice sizes and designs and of other flow restriction and measurement devices was examined in many tests. The objective was to find designs that minimized pressure loss at the flow measurement (restriction) point and, thus, that maintained more water pressure within the process tubes without additional pumping at the inlet end. The knowledge gained from these experiments and from in-pile tests was reported to

*Teflon is a trademark of E. I. duPont de Nemours and Company. 
the $A E C$ as being important in establishing safe operating power levels. Also, it soon was incorporated into the major reactor modification projects that took place at Hanford between 1955 and 1962.

New venturi tubes that replaced the orifices inside the inlet crossheaders smoothed and distributed water flow such that pressure losses of on 7 y $5 \%$ (as compared to $40 \%$ with some of the older devices) occurred. Additionally, flow laboratory studies, as well as in-pile tests during 1955 resulted in changes to the Hanford Water Process Specifications, lowering the coolant $\mathrm{pH}$ to 7.3 in 1955 and to 7.0 in $1956 .{ }^{35}$

\subsection{BOILING CURVE. STUDIES LEAD TO FURTHER REVISIONS IN HANFORD WORKS PROCESS SPECIFICATIONS}

In January 1956, additional generating capacity was added to the 185/189-D Building once again. Throughout that year, investigations of the pressure-flow relationships within the process tubes, known as boiling curve studies, were conducted constantly, using many variables related to higher temperature and to temperatures generated at specific points along the tubes. other experiments tested the flow versus pressure drop characteristics of various orifice assemblies. It was suspected that some of the orifice assemblies in the $H W$ reactors had been reversed inadvertently during installation and were causing cavitation within the process tubes. The trials in the 185/189-D facility aimed at detecting such reversals by studying flow conditions.

A very important series of 1956 tests continued the testing of various devices to allow for C-D of the Hanford reactors while they were operating. The time-saving efficiency of such equipment had been sought for several years, but the first successful trials of full "flush charging" machines took place in the 185/189-D Building. ${ }^{37}$ Further experiments were conducted as flush charging and "flow seating" seemed to cause a rise in fuel rupture rates and as the curvature of process tubes emerged as an important factor in such operations. 38

Additionally, a new hydraulic tube puller, designed to remove process tubes from the reactors when the tubes were not so badly damaged that splitting was required, was tested successfully in the 185/189-D Building. 39 other tests evaluated the integrity of a prototypical design in "pigtails" (the coiled, aluminum tubing connectors between the crossheaders and the individual tube nozzles at the front and rear of the Hanford reactors). 40

During 1957, many important and timely experiments took place in the 185/189-D facility, nearly all related to boiling curves and "boiling burnout" and to locating the upper temperature limits for coolant water passing through and exiting the Hanford reactors. A team of engineers assigned to these experiments in January stated: "Boiling heat transfer is of considerable current interest. Of particular importance is the characterization of conditions called burnout. This is most commonly considered as a point at which transition from nucleate boiling to firm boiling occurs... If the temperature difference becomes excessive at the burnout point the heated surface will be destroyed by melting."41 


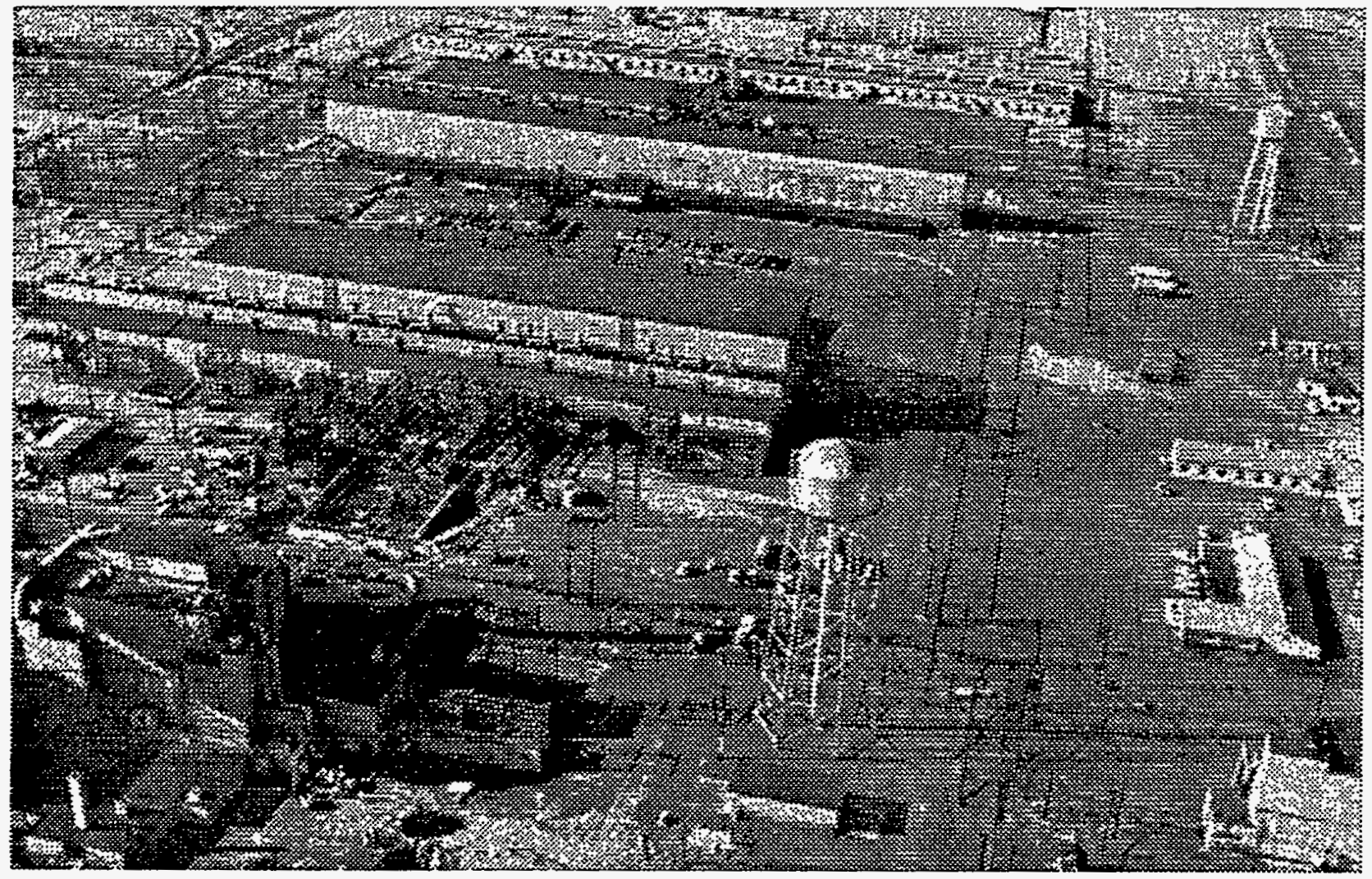

Exterior (above) and interior (below) views of the expansions in coolant pumping capacity added to the 190-D Building in 1956, as part of the "Reactor Plant Modifications for Increased Production." Parameters for safe coolant increases without undue corrosion were developed in the 185/189-D Laboratory.

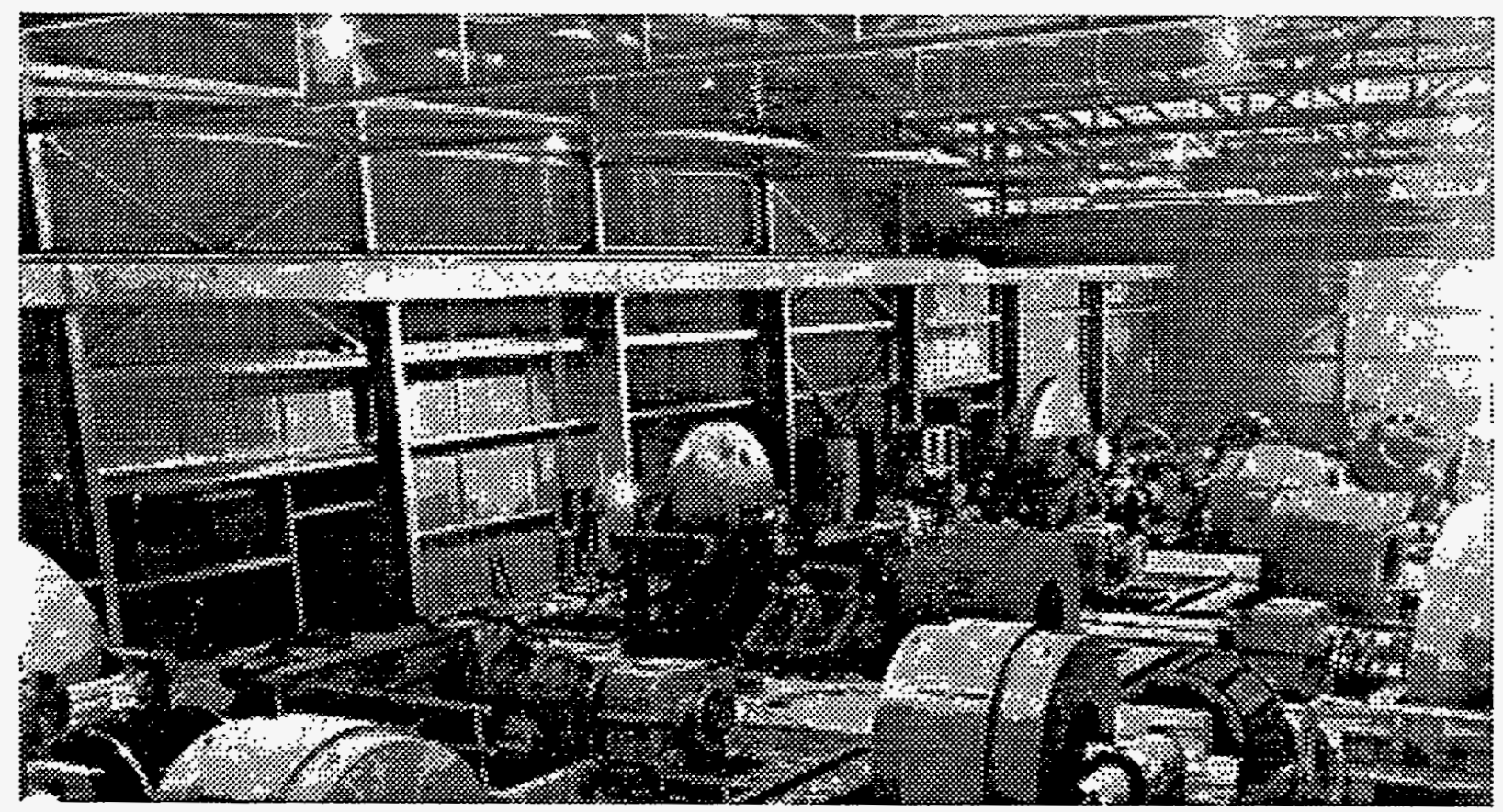




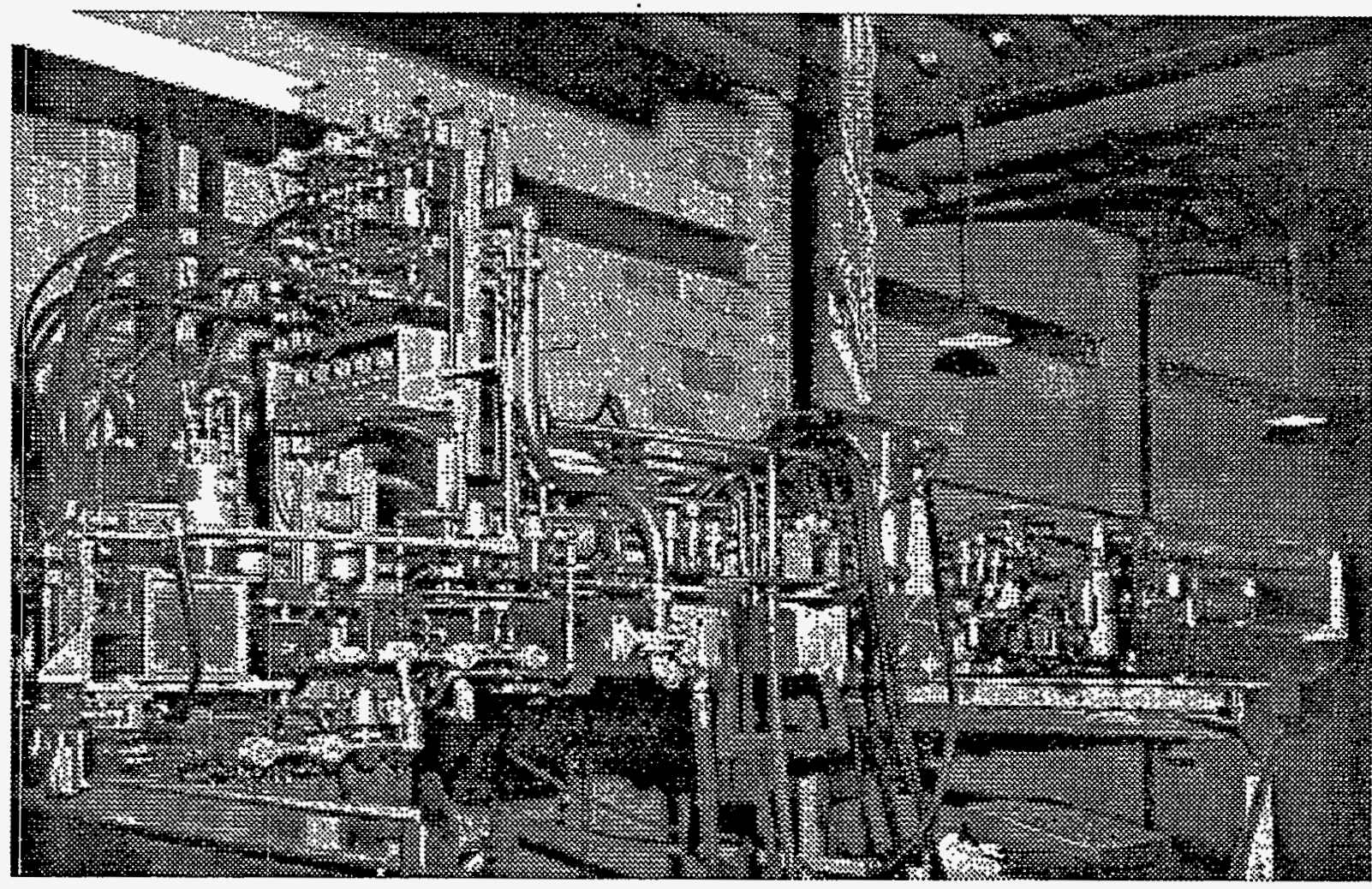

Two views of prototype charge-discharge equipment for the Hanford reactors, during successful developmental and testing stages in the 185/189-D Laboratory, 1956 and 1957.

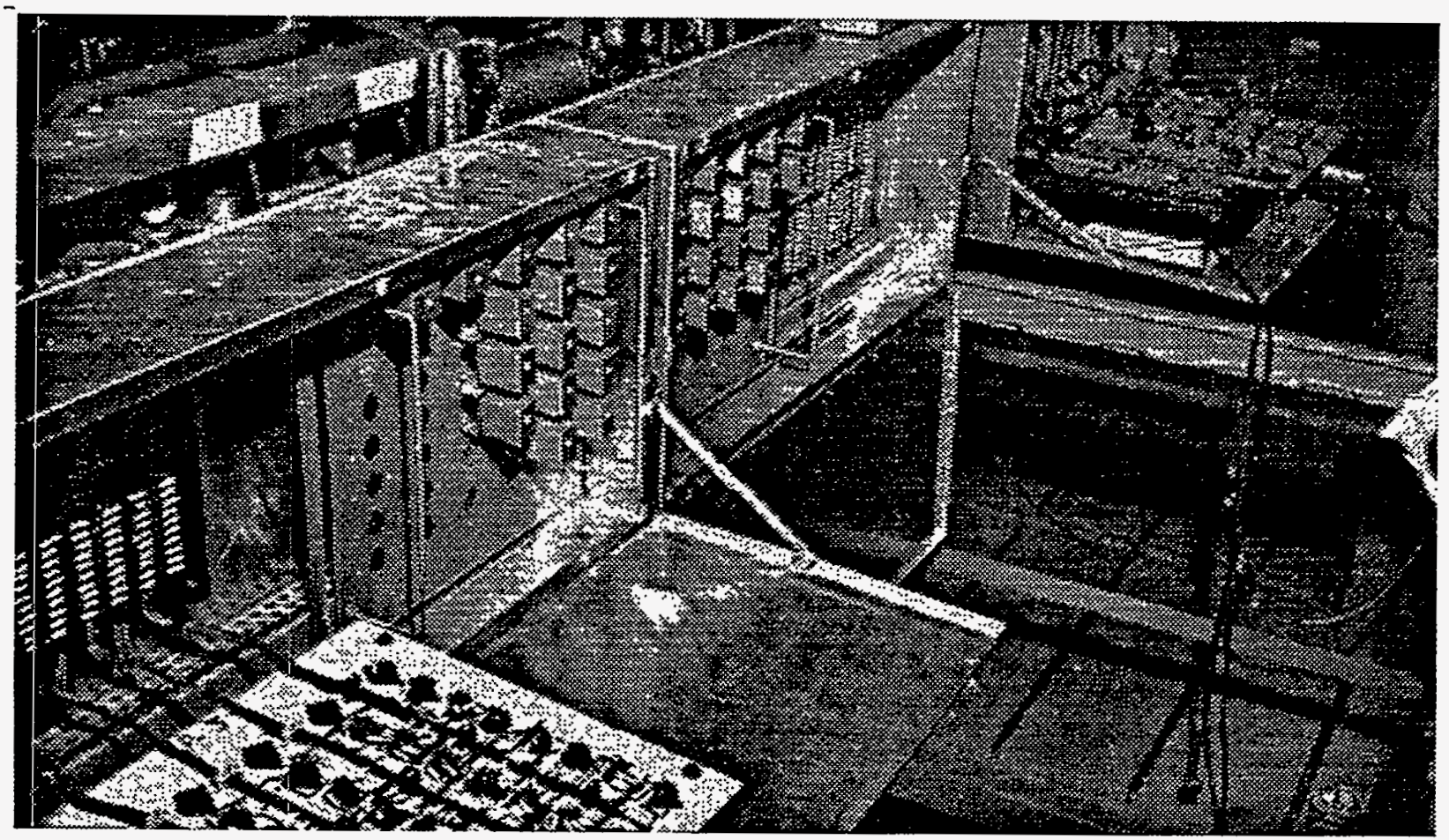


WHC-MR-0465

A 21-ft horizontal test section (a copper-nickel alloy rod centered in a stainless steel pipe), a recirculating pump, two electric preheaters, and a heat exchanger were constructed in the 185/189-D Building and heated by dc current from electric generators. The copper-nickel alloy was chosen because its thermal properties were thought to resemble those of uranium. Heat fluxes from 100,000 to $396,000 \mathrm{Btu} /$ hour per square foot were measured. As water was passed through the assembly, the transition from nucleate boiling to bulk boiling was found to be smooth. ${ }^{42}$

When the basic parameters of the transition to bulk boiling had been established, a long series of experiments that simulated process tube plugging began. Cameras, recorder charts, and other monitoring devices measured temperature, pressure, and flow at various points along test assemblies that used "BDF" reactor-type orifices, KE and KH reactor-type fittings, nozzles, pigtails and venturis, and many other conditions. Change in capacitance was measured by a (then) state-of-the-art sensing device known as a "series capacitive-inductive circuit." The trials were crucially important at that time because a series of major modifications for power increases just was being completed at the oldest reactors and was being designed for the $C, K E$, and KW Reactors.

There was a critical need to gain understanding of the conditions that would result from sudden or gradual plugging of the process tubes at the new power levels. Because the power level increase modification projects at the five oldest reactors all were grouped under Project CG-558 in the Hanford Site project records and the $C$ Reactor modifications were labeled as Project CG-600, these hydraulic experiments became known as the "post-CG-558-600" series. Many different test assemblies were constructed, and trials were run at various kilowatt levels. 43

\subsection{HANFORD PROCESS SPECIFICATIONS AGAIN REVISED BECAUSE OF 185/189-D HORK}

One result of these 1956 and 1957 tests in boiling curves was that the trip-before-instability limit was replaced with the "trip-after-instability" (TAI) limit for the C, KE, and KW Reactors in late 1957. Adoption of the TAI limit in the Hanford Process Specifications meant that at these three reactors, fitted with newer and more favorable coolant equipment, the automatic shutdown gauges that monitored water flow were set to activate only after nucleate boiling had begun in the coolant exiting the process tubes. The higher temperature limitations, thus, allowed increased power levels and increased plutonium production within margins considered to be safe. ${ }^{4}$

Other studies carried out in the 185/189-D facility during 1957 included continued orifice and venturi investigations. A variety of orifice configurations were tested for possible replacement of those then in use in the fringe zones of the KE and KW Reactors. Also, corrosion studies were 
performed on the new Zircaloy-2 alloy* that was being evaluated as the potential replacement material for Hanford's reactor process tubes.

Throughout 1958, tests simulating the sudden or gradual loss of flow through a reactor process tube remained important in the 185/189-D facility. Many of these experiments were conducted to validate the safety standards then in place regarding temperature and pressure. Some of the tests were performed using drilled solid dummy fuel elements and/or internally and externally cooled (I\&E) dummy fuel elements. Fuel elements having complete cylindrical coolant channels down their centers were under intense study at HW at that time because of their greater cooling capacity over traditional solid elements. Within a short time, HW made a nearly complete conversion to I\&E fuel elements, thus enabling reactor operations at higher power levels within a margin of temperature safety.

Other experiments later in the year in the 185/189-D Building were run to characterize the situation that would occur with reverse water flow through a process tube. This condition was postulated to happen if a front hydraulic connector were completely lost during pile operations. Additional trials were executed to characterize conditions following the loss of a rear pigtail. Upon completion of the latter series, the test engineers concluded: "The experimental program demonstrated that the present...protection procedures are adequate. 146

A new development in the 185/189-D Laboratory during 1958 included the building of a high pressure heat transfer apparatus (Project CG-834) that would be able to operate at $2,500 \mathrm{psi}$ at $650^{\circ} \mathrm{F}$ and the receipt of silicon rectifier power generators to power the new equipment. The silicon rectifiers, actually installed in early 1959 in Project CG-661, generated 32,000 A (amperes) at $100 \mathrm{~V}$ (volts) dc. Before these equipment upgrades, the operating levels of the older pressure apparatus had never exceeded $900 \mathrm{psi}$ at $450^{\circ} \mathrm{F}$. With the addition of the new equipment, the older apparatus became known as the "low-pressure" facility. Also in 1958, a "momentum chamber" designed to conduct two-phase measurements of steam and water ratios, was constructed in the 185/189-D Building, and a mock-up of the discharge chutes on the recirculating tubes in the KER facility was built to determine flushing pressures needed in KER discharge activities. ${ }^{47}$

\subsection{NEW PRODUCTION REACTOR EXPERIMENTS BEGIN}

Additional key experiments were begun during 1958 in the 185/189-D facility in the development of heat transfer data for the New Production Reactor (NPR) that later was named N Reactor. Other tests defined the characteristics present when Poison Column Control Facility (PCCF) tubes were inadvertently discharged. These tubes were supplementary control devices installed in some of the Hanford reactors in the mid-1950s. They consisted of ball-valves placed in the nozzles of selected tubes so that additional

\footnotetext{
"Zircaloy-2 is composed largely of zirconium, with additional small percentages of iron, chromium, nickel, and tin.
} 


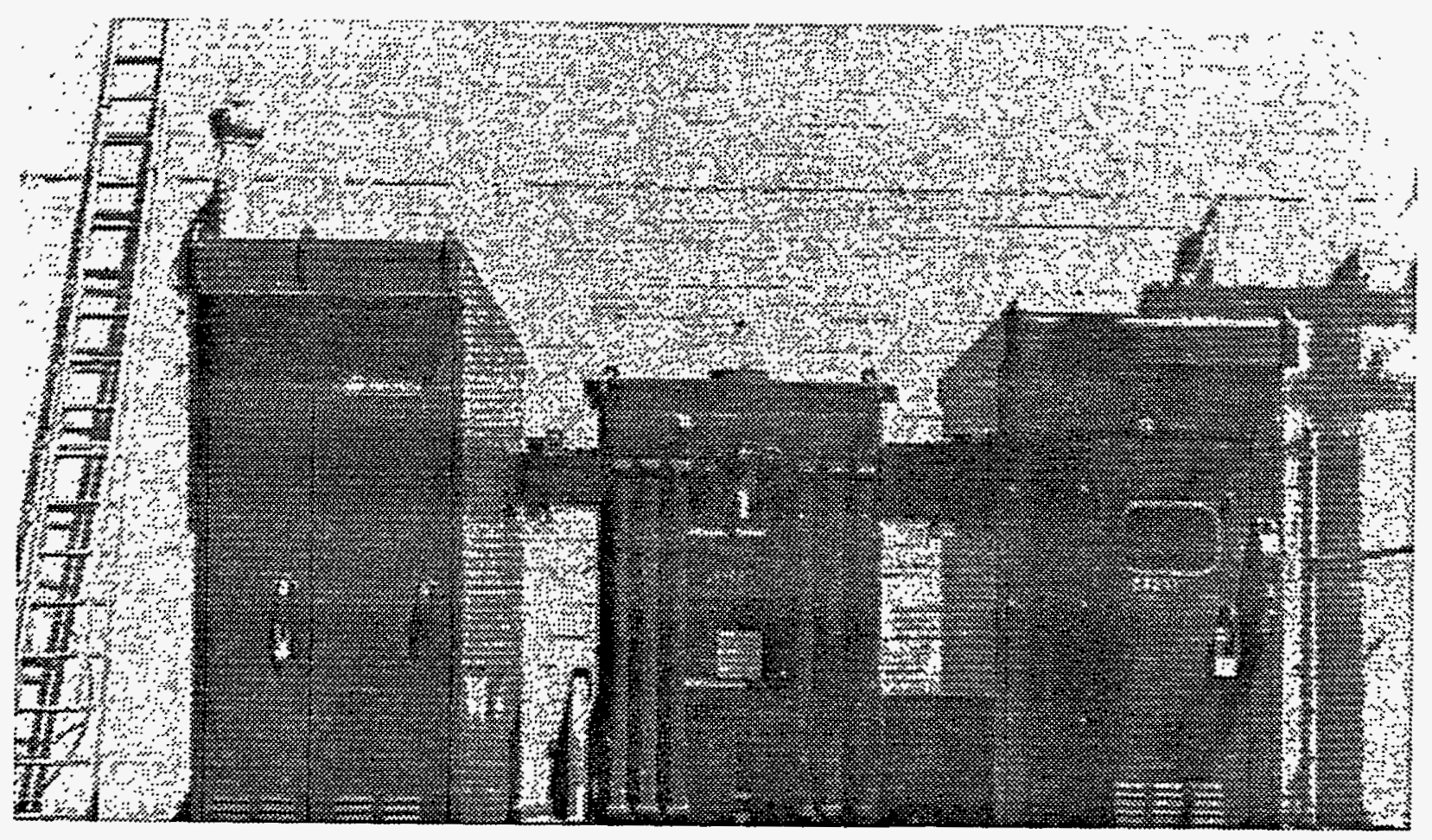

Additional electrical generating equipment, installed in the 185/189-D Laboratory to allow the operation of a new high-pressure heat transfer apparatus, 1958.

neutron-absorbing materials could be charged or discharged during operations to flexibly vary the reactivity in certain reactor zones. Still more trials in the 185/189-D facility that year measured the response time of various resistance temperature detectors (RTDs) just installed as part of upgrades on the existing Hanford reactors.

During 1959, many more unique development experiments went forward in the 185/189-D Building. The new high-pressure heat transfer apparatus was used to test simulations of a prototypical wire-wrapped, seven-element cluster of fuel elements being considered for use in the NPR. Each element in the cluster was very thin ( 0.625 to $0.704-\mathrm{in}$. diameter), 35 to $45 \mathrm{in}$. $7 \mathrm{ong}$, and equally spaced in a 2.067- to 2.70-in. horizontal flow tube. As such, the heat transfer and flow properties of these elements were far different from those of the solid or the I\&E elements previously used in Hanford's reactors. An understanding of every characteristic of the new elements was essential if they were to be recommended for the NPR, so trials continued throughout the year. ${ }^{49}$

Additionally, the low-pressure apparatus in the 185/189-D facility was modified for the execution of numerous tests in the continuing study of flowloss events in the older reactors. These studies led to repeated increases in the operating power levels and, thus, to higher plutonium production rates at HW. The two-phase flow experiments in steam and water mixtures also continued, and further work was done to simulate conditions in the KER water loops and to estabijsh margins of safe operations for those facilities. ${ }^{50}$ 
Also, a so-called "slug-buster" was emplaced near the middle-north end of the 185-D Building. This small facility tested "green" (unirradiated) uranium fuel elements and their claddings until they failed or ruptured. The purpose was to support the development of many types of new fuel claddings and configurations then being considered at HW. Using a dc power supply, electrodes were clamped onto the fuel elements, and current was passed through them to heat them as water was running past them in a tube. Various measurements then were taken as the failures occurred. This small facility operated until it was replaced by the new 330 Building (the Fuel Element Rupture Tests Facility) in 1962.

\subsection{PLUTONIUM RECYCLE TEST REACTOR EXPERIMENTS ADDED TO $185 / 189-D$ FACILITY}

Another very important series of tests conducted in the 185/189-D facility throughout 1959 supported development of Hanford's Plutonium Recycle Test Reactor (PRTR). The PRTR was part of President Eisenhower's "Atoms for Peace" program and was a nondefense reactor designed to test mixed oxide fuel blends for future use in commercial power reactors. The PRTR was heavy-water moderated and operated with 67 fuel elements that each consisted of a cluster or "bundle" of 19 individual fuel rods. Vibration-packed powders and pellets (of plutonium oxide, uranium oxide, magnesium, and other blends) made up the fuel inside the rods. ${ }^{52}$

Obviously, with all the vast differences between these new types of fuels and the reactor fuels previously used at $\mathrm{HW}$, there was a great need for new understandings of heat transfer, consequences of loss of flow, subcooled burnout, pressure drop, pump capacities, and multiple other factors. In the 185/189-D Building, mock-ups of many of the PRTR components were built and tested throughout 1959.53

\subsection{FULL-SERVICE THERMAL HYDRAULICS LABORATORY}

By 1960 , the 185/189-D Thermal Hydraulics Laboratory was one of the few "ful1-service" facilities of its type in the nation. It contained a large shop area wherein most test assemblies were machined, lathed, welded, and assembled. Instruments and electrical components for the experiments also were fabricated and fitted within the building. Instrument calibration equipment, an analog computer, and a 4,000- $\mathrm{ft}^{2}$ storage area also were maintained within the facility. Steam connections existed from the 184-D Power House, and both raw and process water were supplied directly from the 183-D Filter Plant and Chemical Treatment Building. A process sewer 1 ine carried used water from the experiments out to a holdup crib (earth percolation basin) near the Columbia River. ${ }^{54}$

The high-pressure heat transfer apparatus within the 185/189-D facility could be modified to accommodate horizontal or vertical test sections and could test fuel element models configured as single rods, several rods in a 


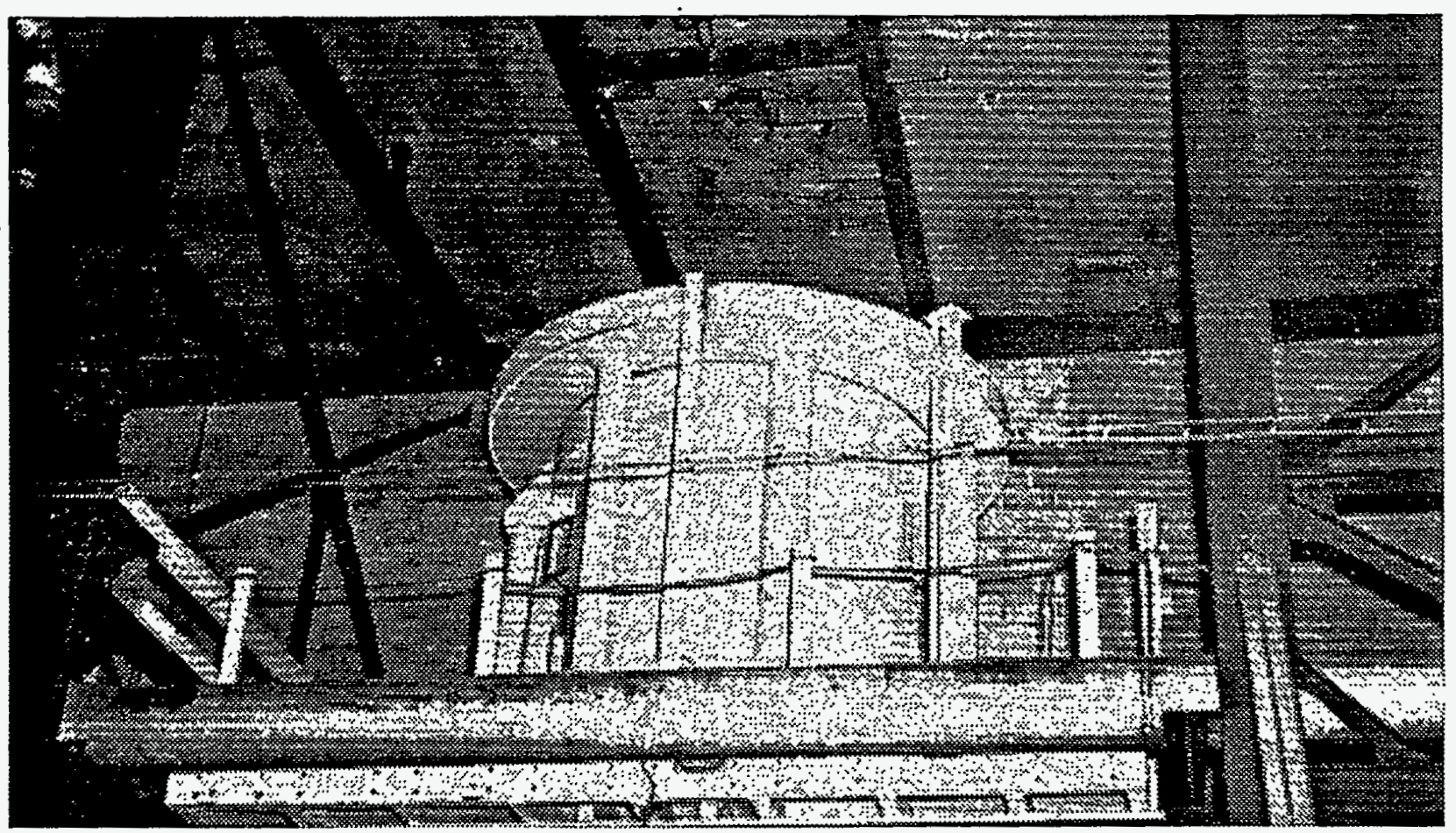

Mock-up of the calandria (vessel that held the reactor core) for the Plutonium Recycle Test Reactor (PRTR), undergoing testing in the 185/189-D Laboratory, 1958.

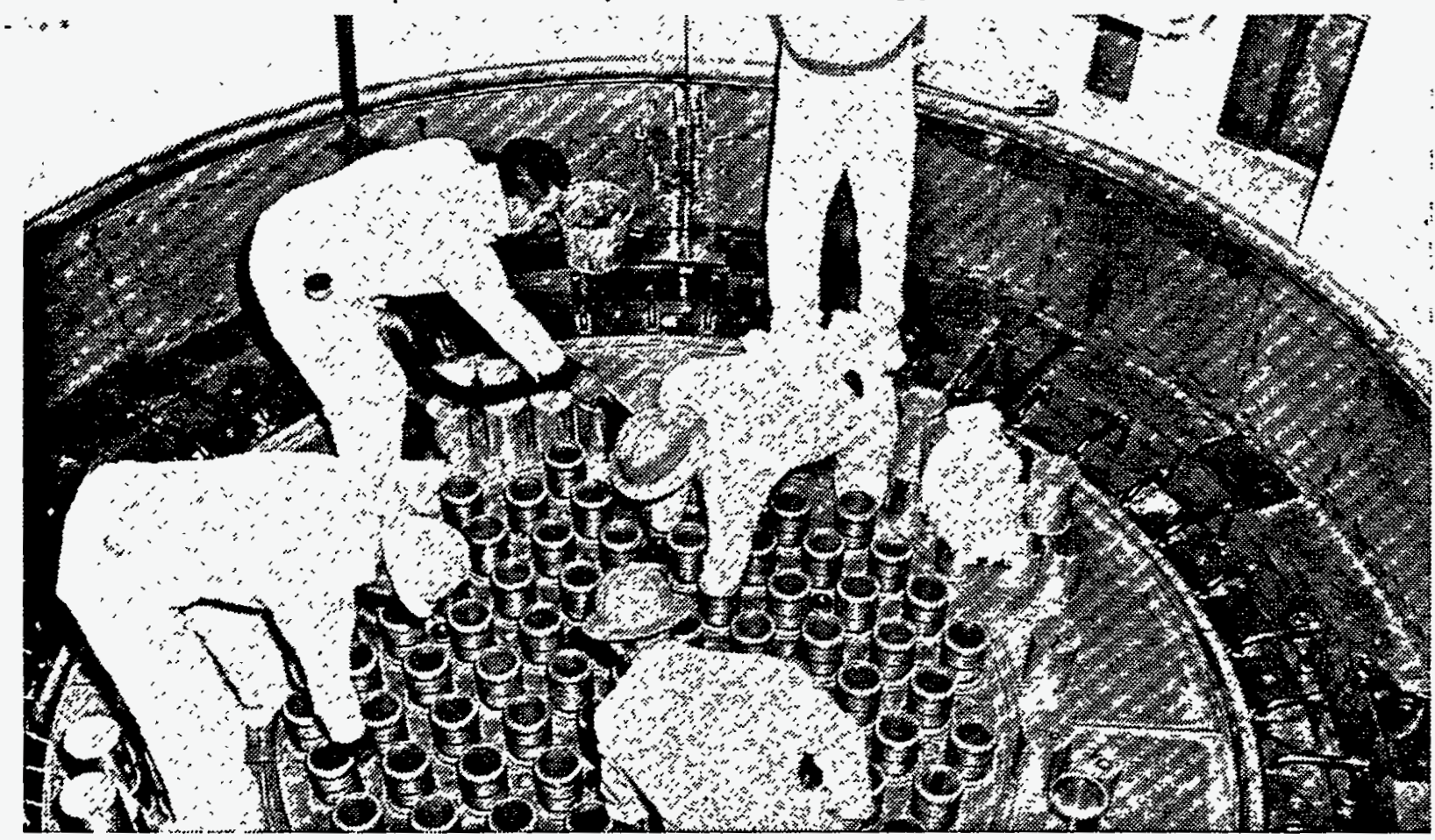

Actual calandria during initial assembly in the Plutonium Recycle Test Reactor, 1960. 
cluster, or the new "tube-in-tube" design being tested for the NPR. It was a stainless steel, recirculating facility with a deionized water coolant obtained from steam condensate and treated in anion-cation equipment. The maximum coolant circulation rate was 250 gal/minute. It continued to investigate subcooled and boiling burnout, single- and two-phase pressure drop, and related studies for the NPR, PRTR, and for other planned Hanford test reactors.

During 1960, a test section consisting of an electrically heated rod in a glass tube with annular water flow was built to observe and photograph circumferential temperature variations resulting from flow eccentricities. Additionally, as the coextruded tube-in-tube fuel element design, which eventually was adopted for the NPR, gained popularity (as opposed to the seven-rod fuel element clusters), a ful1-scale, experimental heat transfer test section that simulated the downstream half of a tube-in-tube charge in the NPR was built on the mezzanine of the 189-D portion of the laboratory. The silicon rectifiers used for heat generation power also were modified during the year.

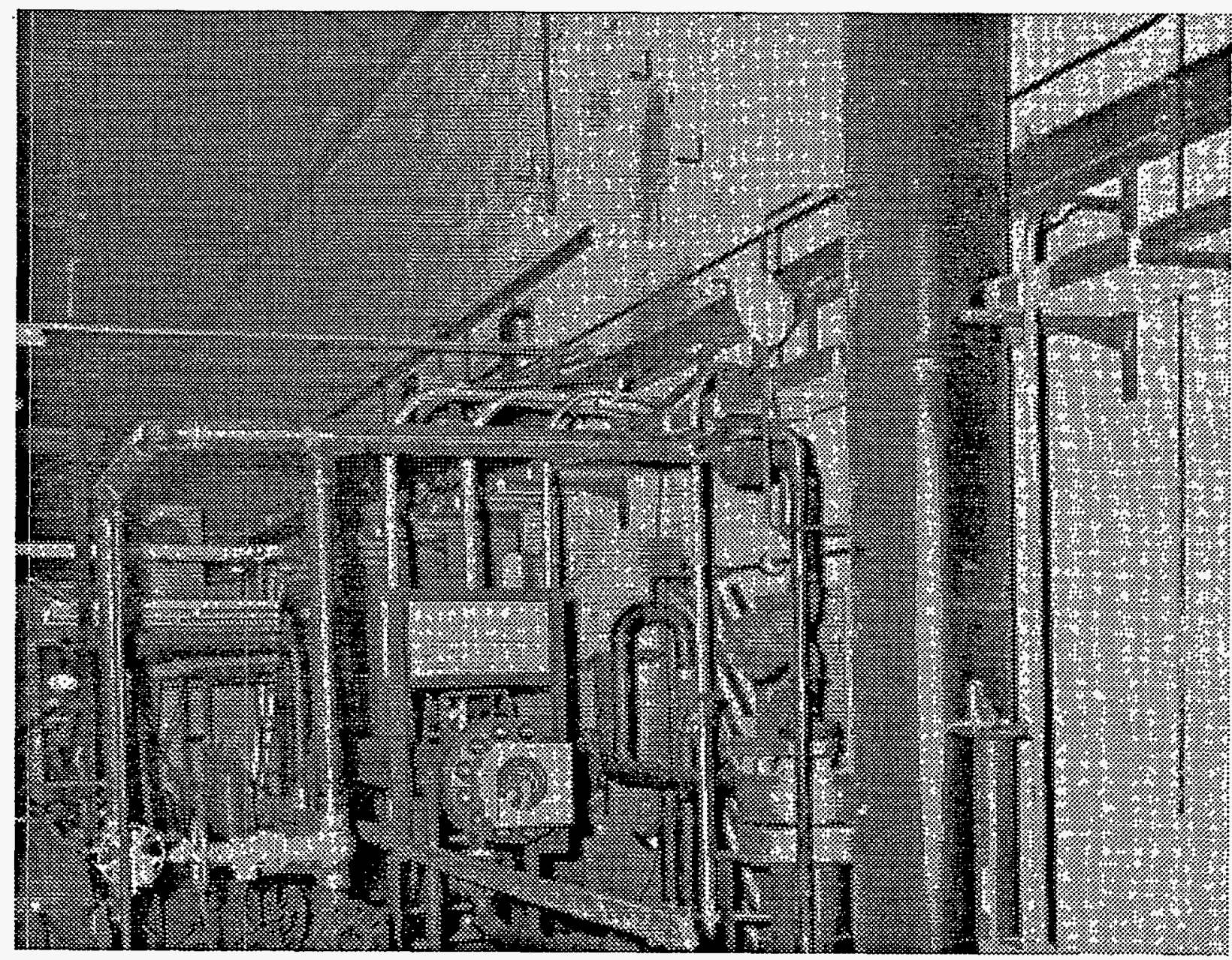

Prototype evaluation coolant loop for the New Production Reactor (NPR) (the name was Tater shortened to $N$ Reactor) in the 185/189-D Building, 1959. 
Studies in support of the PRTR also continued in the high heat transfer apparatus during 1960, including investigations of local heat transfer coefficients on the surfaces of fuel elements in the 19-element clusters, hydraulic stability of coolant channels, protection against inadequate cooling in the event of a process tube leak, boiling burnout conditions, two-phase pressure drop in discharge piping, and flow-controlling orifices. For these experiments, a special test section of 19 Inconel $^{*}$ tubes, each containing a machined ceramic insert to prevent collapse of the extremely thin-walled tube, was built, and the recirculating pump in the high heat transfer apparatus was replaced.

The boiling burnout trials proved to be especially important, in that they demonstrated that several tubes could rupture and meit without being detected by the thermocouples on the tube walls. It was surmised that the tube melting had shorted the electrical connections in the thermocouples. Therefore, fundamental safety changes could be suggested for actual PRTR operations. 56

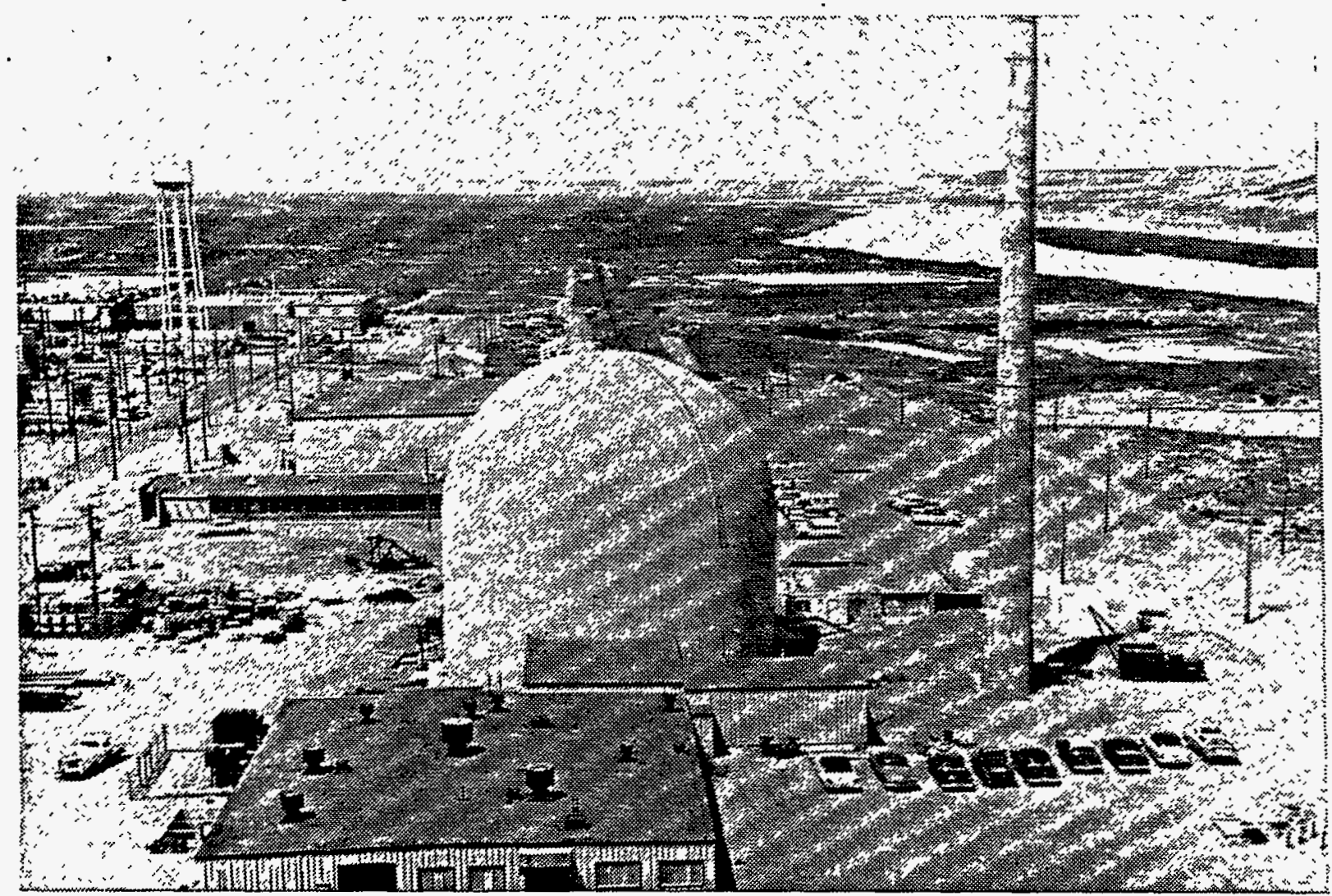

The Plutonium Recycle Test Reactor (PRTR), new in 1960.

*Inconel is a trademark of Inco Alloys International, Inc. It consists primarily of nickel, but also contains chrome, iron, and trace amounts of other metals. 
The low-pressure heat transfer apparatus in the 185/189-D Building also continued its studies in the performance characteristics of the existing Hanford production reactors ( $B, D, F, D R, H, C, K E$, and $K W)$. It was a recirculating facility consisting of an aluminum process tube 7 ined with electrical resisting phenolic resin to prevent electrical leakage from the test element to the housing tube. Downstream of this heated portion of the facility was a reactor nozzle, outlet fittings, and header arrangement that could be varied to simulate numerous actual operating conditions among the eight reactors. Parallel to the main section was a shorter test section that could be changed out to consist of various metals or glass. It was used to investigate boiling, flow mixing, channeling, stratification of vapor phase, pressure drop, and other conditions within process tubes when orifices, pumping rates, temperatures, and other factors were varied.

During 1960, special attention was given to various designs in process tube outlet connectors, and the data supplied by the 185/189-D facility experiments were important in the decision to modify these fittings to allow for increased reactor coolant flow. Additionally, prototypical fuel element projections (flat or "suitcase handle-type" projections) were studied, as were new inlet nozzle assemblies proposed by reactor equipment development personnel.

Tests with eccentrically formed fuel elements continued, as did critical flow stoppage experiments under multiple conditions and simulated electrical power failure trials. The results of these latter tests were presented to the AEC as evidence of the safety of proposed power level increases at the Hanford reactors. Evaluations of the potential organic reactor coolant monoisopropylbiphenyl (MIBP) also took place in another miniature, Tow-pressure Organic Heat Transfer Apparatus.

\subsection{TESTS CONTINUE IN 185/189-D IN SUPPORT OF EXISTING REACTORS, NEW PRODUCTION REACTOR, AND PLUTONIUN RECYCLE TEST REACTOR}

During the years 1961 through 1963, three main types of experiments continued in the 185/189-D Building: Those supporting the existing Hanford production reactors, the NPR, and the PRTR. Questions of ongoing importance to the existing reactors concerned two-phase (steam-water) critical flow phenomenon within process tubes, the effects upon coolant temperatures of eccentrically placed or configured fuel elements within tubes, new types of seal inserts within rear header fittings and nozzles, and various types of fuel element supports. Boiling burnout studies also remained salient, and major modifications were made to the low-pressure heat transfer apparatus in early 1963 to accommodate these experiments. A deaerator, a demineralizer, and a new preheater were installed on this equipment to provide greater flexibility and control over the coolant conditions being studied. The 
consequences of locating both thermocouples and RTDs in the outlet elbows of process tubes, as well as the effects to be expected if a broken "spline" should lodge in a K Reactor outlet nozzle.

One outcome of the improved understandings of burnout conditions achieved through 185/189-D facility studies resulted in a change in the Hanford Process Specifications. As of December 1962, the power level limitations of four of the oldest reactors became based not on megawatt level but on the bulk exit water temperature. This ruling was reversed a year later when the power levels for the eight Hanford single-pass reactors became based on the highest megawatt level previously achieved on a sustained basis. However, in March 1964, the power level limits for the six oldest reactors again reverted to a bulk outlet water temperature 7 imit of $95{ }^{\circ} \mathrm{C} .59$

Studies conducted in the 185/189-D Building in support of NPR development focused on crucial boiling burnout determinations. Numerous experiments were carried out under varied conditions in the mock-up of the downstream half of a NPR process tube located on the 189-D mezzanine. General information also was developed on the heat transfer characteristics of the tube-in-tube fuel elements, the effects of system pressure decreases, and pressure drop data for two-phase flow conditions (both steam-1iquid and liquid-1iquid). 60

After the PRTR started up in July 1961, many additional experiments went forward in the 185/189-D facility to address operating anomalies and to verify the feasibility and safety of tests planned in the actual reactor.. When PRTR tube flow meters began to fluctuate, investigations of sensing lines, suppression devices, throttling valves, and other factors were undertaken. Heat transfer and boiling burnout information under multiple and varied conditions was needed, and a special 19-element boiling burnout test section was built in early 1962 for this purpose. This test assembly failed after just 18 experimental burnout data points were obtained. It was removed and repaired in August 1962.

When PRTR tube powers were increased in 1963, boiling burnout studies were run once again under the new conditions. Loss of pumping power experiments, likewise, were carried out. Because of the incremental loading process used to fabricate PRTR fuel, nonuniform distribution of the plutonium oxide (and, hence, of surface heat flux) sometimes occurred. Many studies were conducted in the 185/189-D Laboratory to determine heat transfer characteristics for such nonuniformiy enriched fuel. The spacing between the individual fuel elements with the cluster also was found to have a vast effect on coolant temperatures.

"A "poison spline" was a long, thin strip of neutron-absorbing metal, usualiy aluminum-boron, used for supplementary reactivity control in the Hanford production reactors beginning in the mid-1950s. A spline was inserted through a slit in the seal of the front process tube cap and pushed down the tube under the active fuel charge to selectively alter the flux distribution. 
WHC-MR-0465

\subsection{AND 1965 BRING MAJOR CHANGES TO HANFORD SITE AND REACTOR OPERATIONS}

The years 1964 and 1965 witnessed significant changes in reactor operations at Hanford. On January 8, 1964, President Johnson announced a decreased national need for special nuclear materials. Soon afterward, it also was announced that the HW reactors would begin to close and that the G.E. Hanford Company would leave the Site, both activities to be implemented in a phased sequence. The first reactor closure (DR) came in December of that year, and in 1965 both $\mathrm{H}$ and $\mathrm{F}$ Reactors closed. As of January 1, 1965, Battelle Northwest Laboratory (BNWL), an offshoot of the Battelle Memorial Institute of Columbus, Ohio, took over the functions of the former Hanford Laboratories Operation as the research division for much of Hanford. With this transfer, the 185/189-D Building was divided with a half-wall approximately in the middle. The BNWL conducted the thermal hydraulics and flow laboratory work in the north sector of the building in support of both the HW and offsite reactors. The G.E. Hanford Company retained the south portion of the building, using it for storage and HW reactor materials and component development testing until it transferred its responsibilities for the eight older reactors to Douglas United Nuciear Corporation (DUN) in September 1965 and for N Reactor (the NPR) in July 1967. The DUN then continued to execute reactor support testing during its tenure at the Hanford Site. N Reactor began operations in December 1963, and the PRTR experienced a major operating accident in September 1965 and was shut down until the spring of 1966. After that time, the PRTR never again conducted full-scale operations, although it did carry out a "batch core experiment" for about 18 months beginning in July 1966.

Throughout 1964, work in the 185/189-D Building continued without substantial change from the work conducted during 1961 and 1963, except that studies concerning the single-pass $\mathrm{HW}$ reactors focused on the newer ones (KE and KW) that would be the last to close. For $N$ Reactor and the PRTR, experiments focused on two-phase flow mixtures in high-pressure systems and their relationships to reactor safety, boiling burnout (including comparisons of data taken in vertical and horizontal positions), the pressure drop effects of obstructions within process tubes, and the temperature transient conditions resulting from a break in an $\mathrm{N}$ Reactor inlet connector. For this work, the high-pressure heat transfer apparatus was operated sometimes at 3,800 $\mathrm{kW}$, its highest level to that date. One key result of the PRTR thermal hydraulics studies in the 185/189-D Building was the conclusion that power density in the core "could reasonably be increased up to 3.6 times the present level without encountering flow instability and without relaxation of the boiling burnout safety limits." This finding, made early in the year, was a crucial precursor to some of the operating decisions for PRTR experiments that followed. Preliminary studies also were begun in 1964 to define operating characteristics and parameters for the High-Temperature Lattice Test Reactor (HTLTR) and dry nitrogen gas-cooled test reactor that were authorized at HW in 1963 and constructed during 1966 and $1967 .{ }^{\circ}$

From 1965 to 1967, studies in the 185/189-D Building covered most of the same topics as those examined during the early 1960s, but with decreased emphasis on the single-pass reactors and the PRTR and increased emphasis on $N$ Reactor. Developmental studies in support of the HTLTR remained minor. 


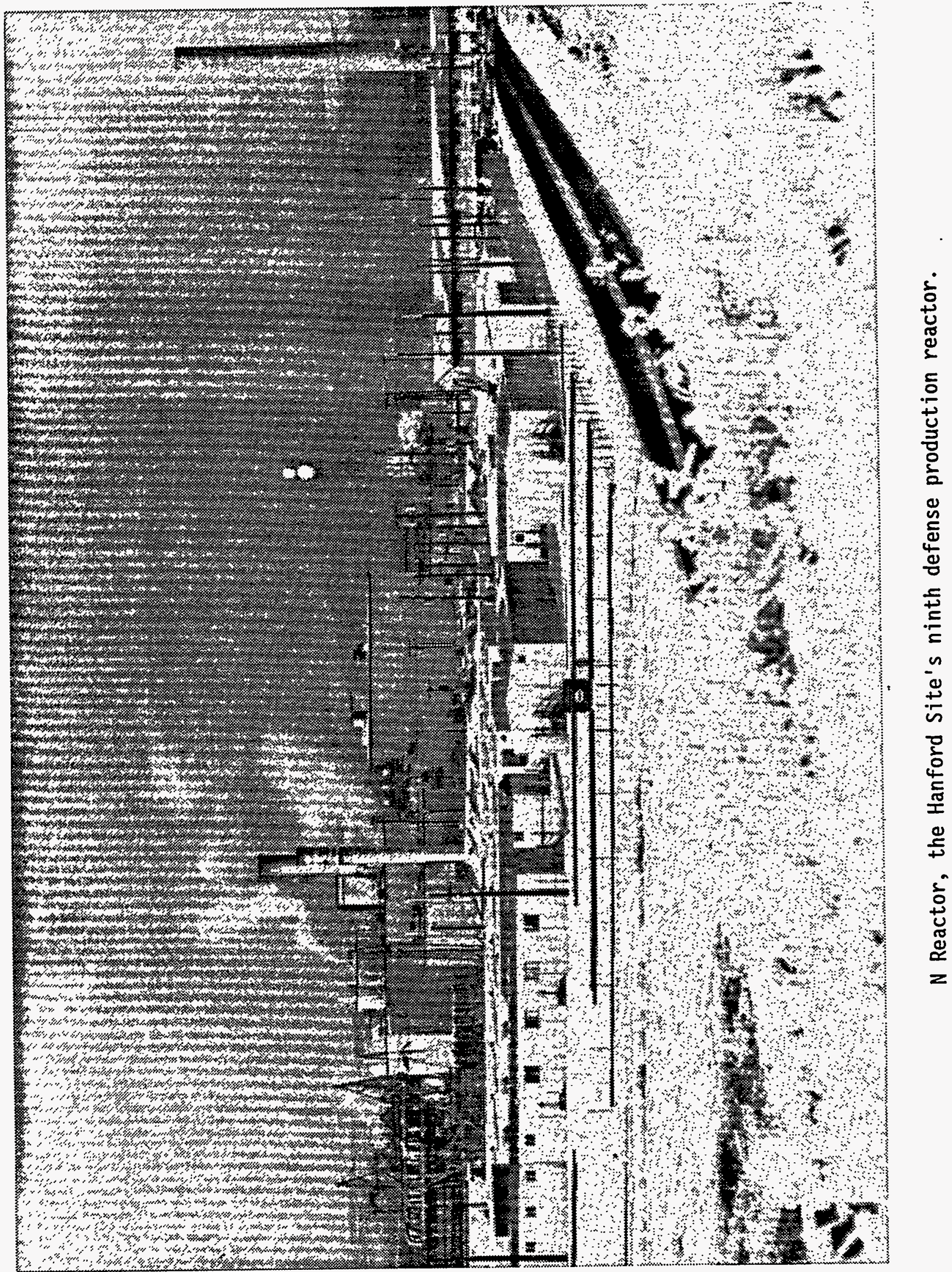




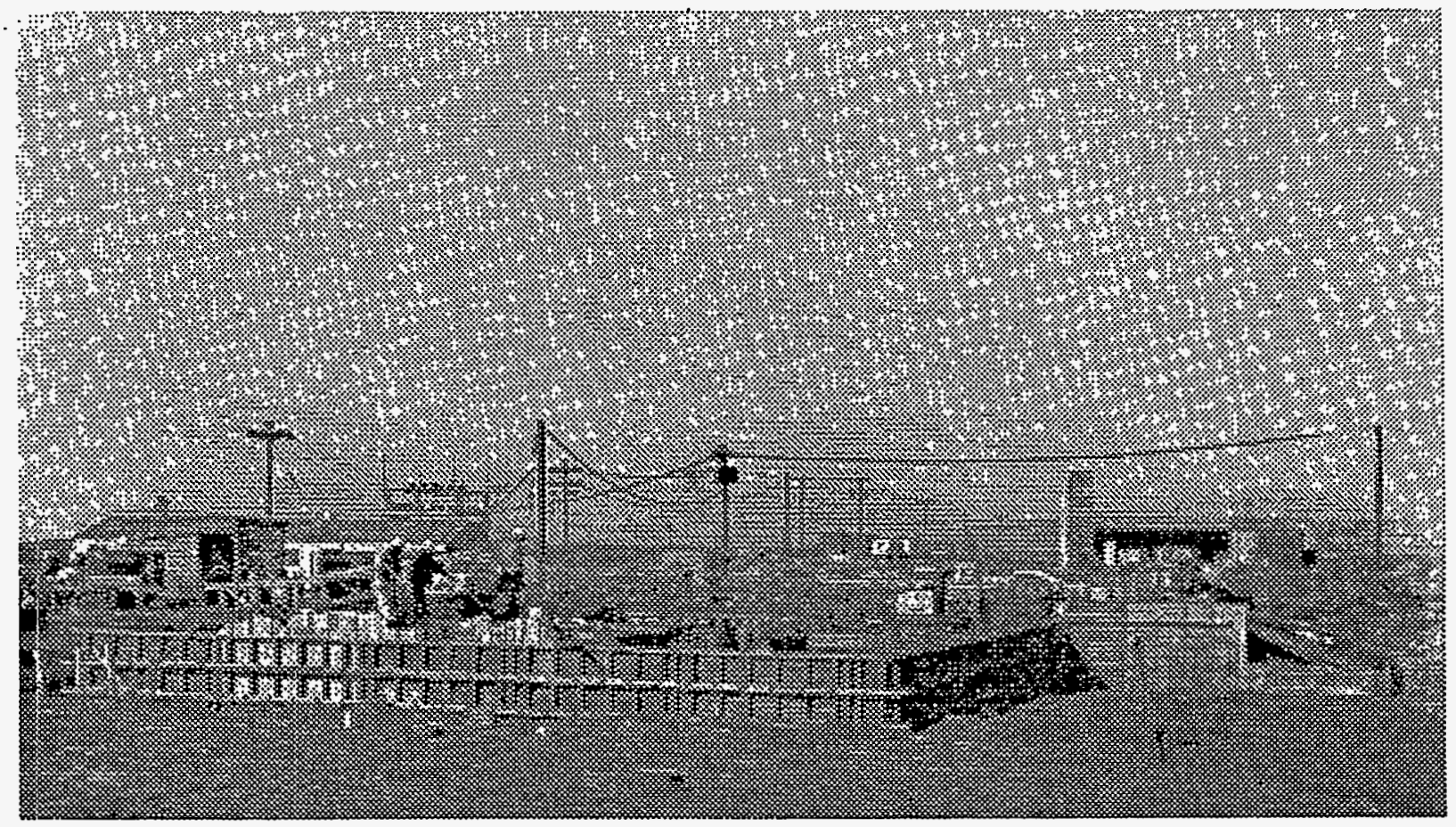

Two views of the High-Temperature Lattice Test Reactor (HTLTR), showing construction in 1965 (above) and the fuel insertion assembly in 1969 (below).

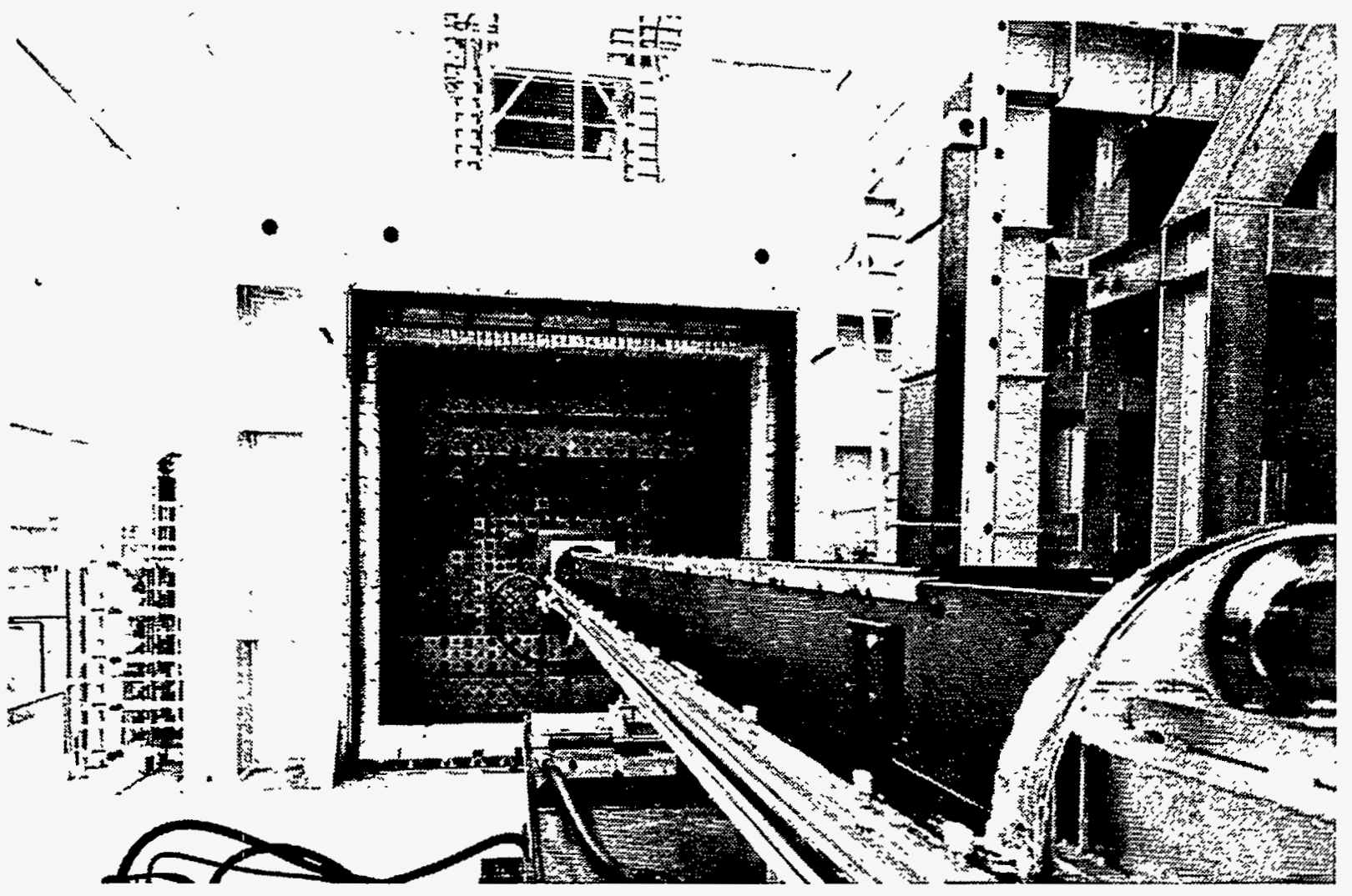


Among the subjects investigated in 1965 was a thorough study of the hydraulic characteristics of the $N$ Reactor primary coolant 10op; the consequences of fuel element plugging within $N$ Reactor tubes; the choking condition, known as critical flow, that occurred when steam and water were simultaneously discharged to the atmosphere adjacent to a pipe fitting; riser-to-riser pressure drop; and pressure differentials among the three subchannels of the $N$ Reactor tube-in-tube fuel configuration. Interchannel flow between fuel elements in $N$ Reactor tubes, the effects of variations in seal rings used in the inlet ends of fringe tubes, and the thermal hydraulic parameters of "coproduct" (tritium-producing) lithium aluminate fuel elements also were studied with vigor. Numerous pressure drop, temperature, and other measurements were taken in the mock-up 10ops.

In 1966; steam-generating equipment and tie-ins were completed at $N$ Reactor, and it became the first dual-purpose (defense and electric power production) reactor in the nation. ${ }^{65}$ During 1966 and 1967 , many experiments conducted in the 185/189-D Laboratory supported this unique reactor, including vibration testing of the coproduct fuel elements, more pressure drop studies for $N$ Reactor tube-in-tube fuel, and more boiling burnout trials with both normal and coproduct $N$ Reactor fuel. Other investigations tested crossflow mixing between parallel flow channels within bundle fuels, departure from nucleate boiling studies with bundle fuels, and simulated evaluations of the pressure tube and fuel failure event that had occurred at the PRTR in September 1965.

Further, a complete mock-up of the $K$ Reactor biological and thermal shields with a VSR channel opening was constructed in the 185/189-D Building to conduct trials of new shield boring machines. Orifice tests to solve the recurrent problem of plugging of the flow rate sensing lines in the older reactors, as well as examinations of interchannel flow through fuel element junctions in a C Reactor fuel model, also were performed. The HTLTR support experiments also included simulation work. ${ }^{66}$

\subsection{FAST FLUX TEXT FACILITY DEVELOPMENTAL TESTING BEGINS IN THE 185/189-D FACILITY}

For the most part, the 1968 and 1969 studies in the 185/189-D Laboratory represented continuations and variations on topics that had been examined previously in the facility. During 1968, evaluations were made of different types of springs on $N$ Reactor fuel elements, zone temperature monitor protection requirements designed to "scram" (shut down) N Reactor before boiling burnout conditions, the thermal hydraulics characteristics of a new type of $N$ Reactor fuel elements (Mark IV, containing $0.947 \%{ }^{235} \mathrm{U}$, as opposed to the Mark I-C fuel previously used), and of the temperature stabilizing effectiveness of "mixer-spools" used in the older reactors.

\footnotetext{
"Mixer spools were special, 2-in.-long attachments with holes in them, welded onto the standard fuel elements used in the older reactors to intermix flow streams above and below the fuel elements. They were needed to equalize the flow at the top and bottom of the cooling annulus to alleviate hot spots and other temperature disparities.
} 
Studies were conducted to establish general understandings of mass transfer at the solid-liquid interface of two-phase film flow within annular ducts. ${ }^{67}$ During 1969, tests of the simulated flow monitor sensing 7 ines continued in preparation for an $N$ Reactor line replacement project that began Tate that year. Studies of critical flow of coolant through reactor nozzles also went forward, as did trials of variable orifice designs, examinations of the hydrodynamic drag coefficients when various obstructions were placed within flow channels, and mock-ups of tests that were performed that year. to analyze primary loop leaks within $\mathrm{N}$ Reactor.

One key addition in 1969 was the beginning of developmental testing for the Fast Flux Test Facility (FFTF), the prototype being built at Hanford for the nation's "breeder" reactor program." The earliest tests evaluated an electrically heated, seven-fuel-pin assembly model to determine temperature gradients between wall and central coolant channels, thermal stress levels, and potential hot spots caused by a spiral wire wrap that was planned to be used around each fuel pin. 68

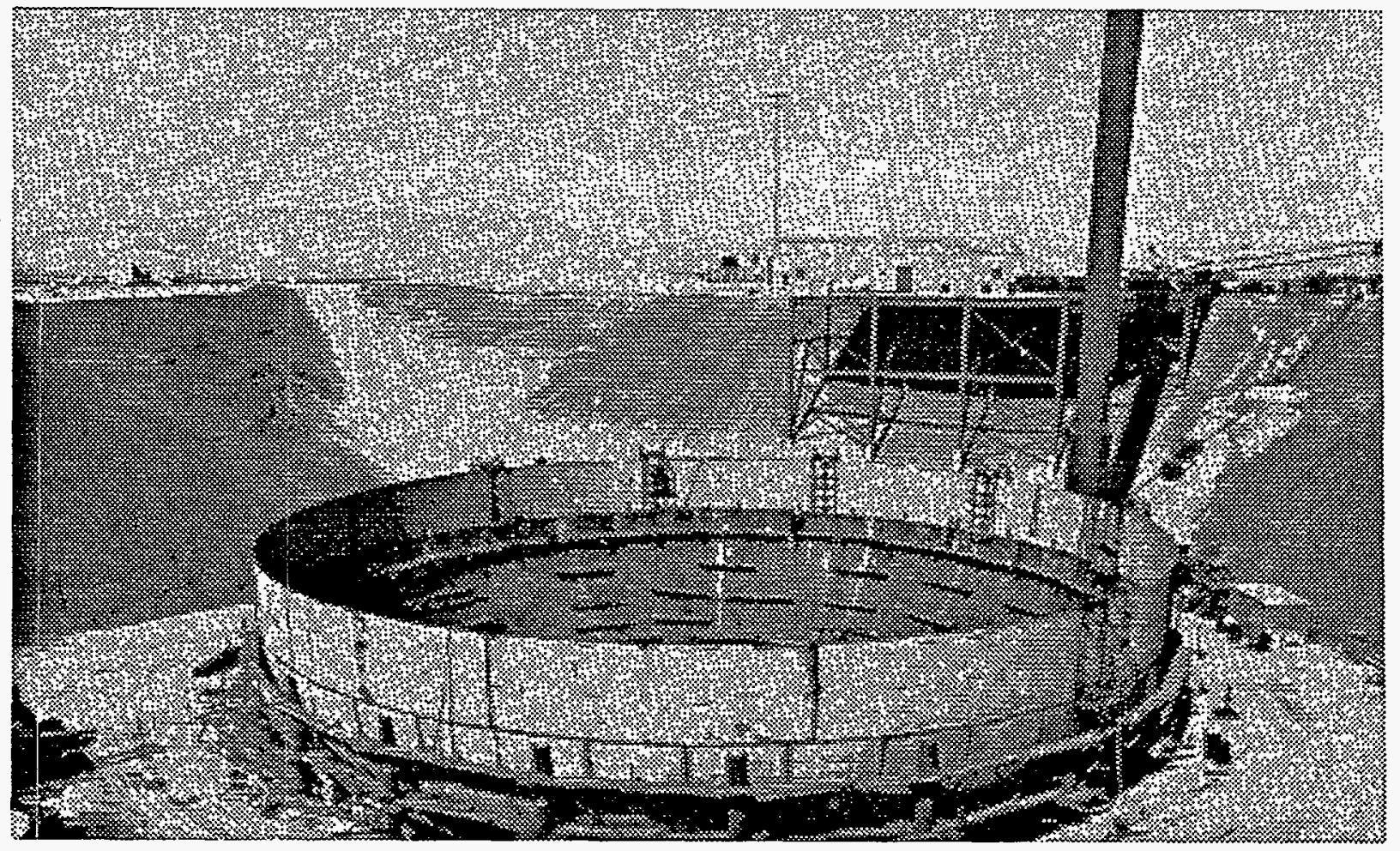

The Fast Flux Test Facility (FFTF), during its early construction phase, in 1971. Initial developmental studies in coolant flow for the FFTF were performed in the 185/189-0 Laboratory during 1971 and 1972.

"Breeder reactors are those that use a depleted uranium "blanket" surrounding their cores to capture extra neutrons that otherwise would escape during the fission process. The depleted uranium absorbs the neutrons and transmutes into plutonium. Thus, breeder reactors end their fuel cycles having produced more plutonium than the amount (in the fuel) with which they began. 


\subsection{AND 1971 WITNESS END OF SINGLE-PASS REACTOR OPERATIONS AT HANFORD}

The years 1970 and 1971 saw the respective closures of KE and $\mathrm{KH}$, the last of the single-pass reactors at the Hanford Site. (D Reactor had closed in 1967, B Reactor in 1968, and C Reactor in 1969). ${ }^{69}$ With N Reactor then the only defense production reactor still operating, all studies conducted in the 185/189-D Building by DUN supported this reactor. Studies carried out by BNWL branched into the private sector and other offsite areas allowed by the research and development contract, so that BNWL carried out thermal hydraulics and flow and heat transfer investigations in support of N Reactor, FFTF, and various other entities.

During 1970 and 1971, DUN examined fuel flushing and movement within tubes testing for $N$ Reactor, different designs in fuel spacers, burnout conditions and measurements (especially focused on the zone temperature monitors), modified designs in venturis within header fittings, fuel support designs and wear characteristics, various features of the inlet connector butterfly valves used for flow control during $C$ and $D$ operations (the $V$ - 11 valves), leaks in the seal rings and hubs used on $\mathrm{N}$ Reactor pipes; and criteria for a new horizontal safety and control rod recirculation cooling system. Additionally; a complete training mock-up for a major V-12 valve replacement activity $\mathrm{planned}$ for $\mathrm{N}$ Reactor was built as Project DCE-551 in the $185 / 189-D$ facility in $1971 .^{70}$

During the same period, BNWL conducted one last study that concerned the Hanford single-pass reactors, an examination of steady state thermal hydraul ic characteristics of a fuel column mock-up that had been "overbored" (enlarged) by 1 in. ${ }^{71}$ In support of $N$ Reactor, BNWL examined pressure losses within the fuel columns and conducted loss-of-coolant heat transfer experiments. ${ }^{72}$ A liquid mixture of sodium and potassium known a "NaK" (a less volatile simulation of pure liquid sodium) was brought into the 185/189-D facility during this period when BNWL was evaluating the heat transfer capacities of the liquid sodium that would be used to cool the FFTF. The BNWL also designed and built a 37-pin, instrumented fuel subassembly for irradiation in the Idaho National Engineering Laboratory's Experimental Breeder Reactor II (EBR-II).

In late 1971, FFTF support work was taken up by a new design and construction contractor, the Hanford Engineering Development Laboratory (HEDL), and coolant mixture studies for the FFTF using water were conducted in the 185/189-D Laboratory. 3 In private contract work in support of commercial power reactor designs, BNWL also performed critical heat flux (boiling burnout) and two-phase hydraulic investigations for boiling water reactors. ${ }^{74}$

The years 1972 through 1975 saw a clear divergence in the work of the DUN and BNWL organizations within the 185/189-D Building. The DUN experiments were focused solely on $N$ Reactor and were taken up by the replacement operating contractor United Nuclear Industries, Inc. (UNI) in 1973, while the BNWL studies supported private commercial reactor development for a variety of customers. The DUN-UNI trials simulated many upgrade and replacement programs needed at $N$ Reactor and, thus, allowed crafts people to practice in nonnuclear conditions the techniques they would need to use in actual radiation zones. 
For the first time, in December 1972, an $N$ Reactor control rod failed because of top problems related to graphite distortion in the pile. An alignment block known as a T-block fell into the HCR channel, thus impeding the path of the rod. At that time, a complete simulation, duplicating in-reactor conditions as nearly as possible, including graphite distortion configuration, was built in the 185/189-D facility. This mock-up was scrammed a total of 1,343 times and then was further distorted to resemble expected reactor conditions after 1985. The new configuration then was scrammed 25 times before the tests were stopped because of broken graphite blocks. As a result of these experiments, engineers assigned to the project concluded: "There was definitely nothing revealed in any of these tests which indicated that the blocks would not perform their desired function until 1985."

Among other projects practiced and performed by DUN-UNI on the $\mathrm{N}$ Reactor models in the 189-190-D Building from 1972 through 1975 were replacements of many varied gaskets and valves, process tube flow monitoring tubing, development testing of RTD spray shields, confirmation testing of strap-on RTD connectors, thermal hydraulics studies necessary for the conversion of the reactor's shield cooling system to a recirculating mode, measurement devices and procedures to determine the thickness of process tube connectors, and development of the Technical Specifications (safety standards that replaced the older Hanford Process Specifications) for boiling point suppression equipment capable of providing low pressure protection.

Additionally, freezing as a technique to block the flow to block valves in the rupture monitor rooms, developmental testing of prototype equipment to measure process tube elongation and elongation forces, work to determine procedures for establishing once-through coolant flow during major reactor component maintenance, trials of $V-12$ valve vibrator installation techniques, and flow testing of Mark IA fuel was carried out in the NPR-Prototype Concept Evaluation Loop in the 185/189-D facility. ${ }^{76}$

During the same years, BNWL executed many flow and thermat hydraulics trials in connection with developmental contracts for various power reactors. It analyzed the effects of uniform core blockage on pressurized water reactor core flow during reflood following a postulated loss-of-coolant-accident; the core flow distribution during the downflow period during a loss-of-coolant accident; reviewed the effects of housing wall temperature on heat transfer results; examined the thermat hydrautics of a new, fusion-fission hybrid, gas-cooled reactor concept; studied flow and pressure in rod bundle subchannels containing blockages; and evaluated "dry" versus "wet" cooling tower heat removal systems for pressurized reactors."

In 1972, the HTLTR lost its funding to the FFTF program and closed. The final FFTF support experiment using NaK was carried out in the 185/189-D Building in earty 1972. Thereafter, this work moved to the new 337 High-Temperature Sodium Test Facility. ${ }^{78}$

During 1976 through 1979, the experiments conducted in the 185/189-D Building by the two contractors, UNI and BNWL, remained typical of the few preceding years. The UNI carried out work in support of $\mathrm{N}$ Reactor operations, while BNWL, which officially became the Pacific Northwest Laboratories (PNL) in 1977, did limited $N$ Reactor support work and a variety 


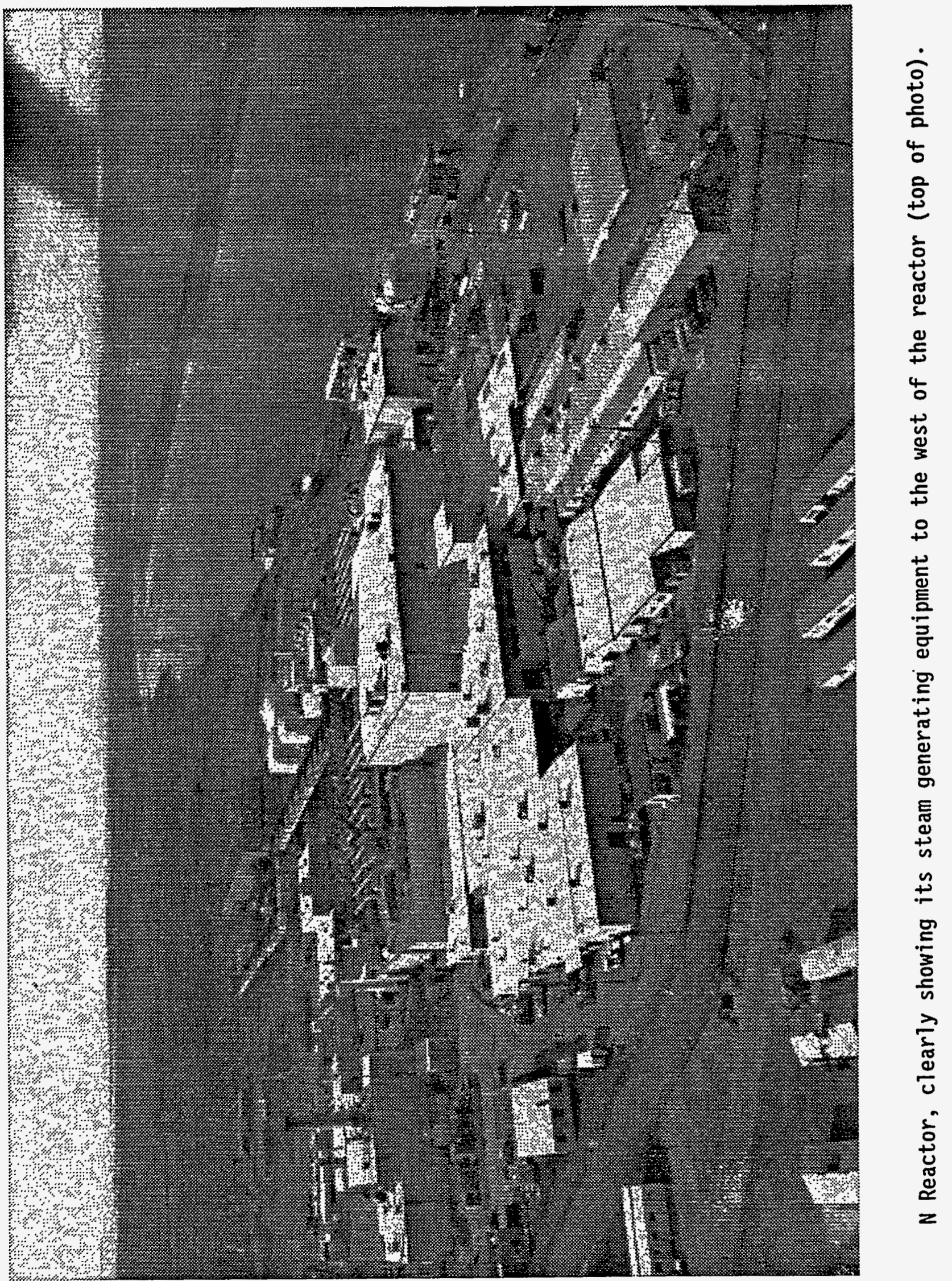


of experiments for offsite power reactors. Among the projects examined by UNI were a backup fuel cladding failure monitor, new flow-temperature data logger equipment, the effects of "upsetting" on the physical and flow properties of Zircaloy-2 pressure tubes, much valve simulation and testing work, reliability upgrading of the fog spray system, seismic and reliability upgrading of the confinement filter spray system, process tube drag measurements, and the use of new ultrasonic flowmeters. Thermal tests of new graphite boron carbide safety shutdown balls proposed for $N$ Reactor were conducted in a furnace and a compression machine located in the 185/189-D facility.

The BNWL developed computer programs to analyze the thermal hydraulic characteristics of rod bundle nuclear fuel elements and cores and then compared the program results to actual laboratory results achieved in test equipment in the 185/189-D Building. Among other programs, it al so conducted experiments to evaluate the effects of sleeve blockages on axial velocity and intensity of turbulence in unheated rod bundles, investigated and summarized several concepts in "dry" and "wet" heat removal systems for pressurized reactors, established a set of preliminary requirements for a helium-cooled blanket heat removal system for fusion reactors, began using laser Doppler anemometer techniques in taking fluid flow measurements in rod bundles, developed a nuclear fuel pin simulator for testing loss-of-coolant-accidentrelated studies of Zircaloy-2 oxidation, and studied the single-phase flow fields around steam generator tube support plates in pressurized water reactors. ${ }^{80}$ The BNWL also carried out a limited number of experiments in support of $N$ Reactor operations, including boiling burnout studies of the conditions in the inner annulus of Mark IV fuel elements fitted with various types of spring supports. 81

\subsection{SIMULATIONS IN 185/189-D BUILDING AID IN N REACTOR REPAIRS IN 1980s}

As the $N$ Reactor approached and arrived at 20 years old in the early 1980 s, it began to experience system failures of many types. During these years, UNI work in the 185/189-D facility served a vital function in building and testing mock-ups and procedures needed to facilitate repairs to the reactor. During this period, the 185/189-D Laboratory was operated by the Systems and Equipment Development Section of UNI. Its mission was to "develop new systems and components not available on the current market to support the programmatic functions of the 100-N Reactor... define detailed performance criteria for complex mechanical and instrument systems and components...test new components for compliance with performance criteria and specifications... conduct advanced systems studies and development... provide training simulations design, development and operation...perform on-reactor and supporting facilities equipment failure analyses..." and many other related tasks. The 185/189-D operating section also performed instrument calibrations and reviewed computer applications to simulations and development projects. Examples of "special processes instructions" included the development of procedures for $N$ Reactor tube shortening and safety ball channel repair. 82 
One fundamental problem that accompanied the aging of $N$ Reactor was that of swelling and distortion of the graphite stack (core). The graphite stack was an assembled unit of blocks, with tube blocks oriented front to rear and filler blocks oriented side to side between each tube block layer. The blocks were keyed together except at slip. joints provided across the center of each layer. Under prolonged irradiation, the $N$ Reactor graphite by the early 1980s had contracted linearly in the parallel direction (along block length) but had contracted more slowly and eventually had expanded in the transverse direction (block thickness direction). The slip joints could not accommodate all of the local distortion, and some block cleavage had occurred, along with actual separation of blocks within central sectors of the stack. Such changes in the stack had produced distortions in the horizontal process cooling and safety rod tubes that were most severe in the side fringes, even causing "significant charging problems" by 1982. Vertical tube distortion, especially in the center of the reactor where transverse contraction had resulted in a total sag of about 3 in. Additionally, tubes became elongated under the stress of irradiation, and many "minimal" connector clearances were found during the 1982 summer outage.

During the early 1980s, a mock-up of portions of the $N$ Reactor stack, complete with current graphite misalignments and with horizontal and vertical tubes exactly duplicating the curvature caused by the misalignment, was reconstructed in the 185/189-D Building. During 1984 and 1985, procedures were developed in the facility for HCR channel distortion and blockage testing, and standards were validated for the testing of new tube materials.

In 1986 and 1987, a special process tube removal jack, with an expanding mandrel adapted to the bent and blocked tubes and channels, was developed and tried, as was new equipment for profiling the curvature of the HCR channels and for characterizing the inside thicknesses of various points along deformed tubes.

Al so within the 185/189-D Building was the $N$ Reactor Loop Component Test Facility, a high temperature, pressurized, recirculating demineralized water test 10op. It also had the capability to run single-pass dump tests. It consisted of a 55-hp liner motor centrifugal pump, a 200-hp four-stage special high-pressure pump, two single-pass counterflow heat exchangers (each designed to remove 2,700,000 Btu/hour), a 300-kW immersion line heater, main loop piping fabricated of 4-in. Schedule 160 seamless carbon steel, the makeup water system, the cleanup water and sampling system, a pressurizer, and control and monitoring instrumentation. The makeup water system was composed of a demineralizer, 650-gal demineralized water storage tank, rapid-fill centrifugal pump, a high pressure injection pump, and a chemical feed tank. The cleanup and sampling water system was composed of a restricting orifice to 7 imit flow, a heat exchanger to cool the process water, filters, and a flow indicator.

Within the $\mathbf{N}$ Reactor Loop Components Test Facility, other reactor difficulties were modeled and/or evaluated, including characterization of leaks in the primary flush lines of the emergency core cooling system, flow tests involving the partial operation or shutdown of various valves, replacement plans and procedures for these valves, investigations of the thermal hydraulic bases for operating the reactor when only four of its five cells were operating (resulting from the closure of Cell. Number Five for steam 
WHC-MR-0465

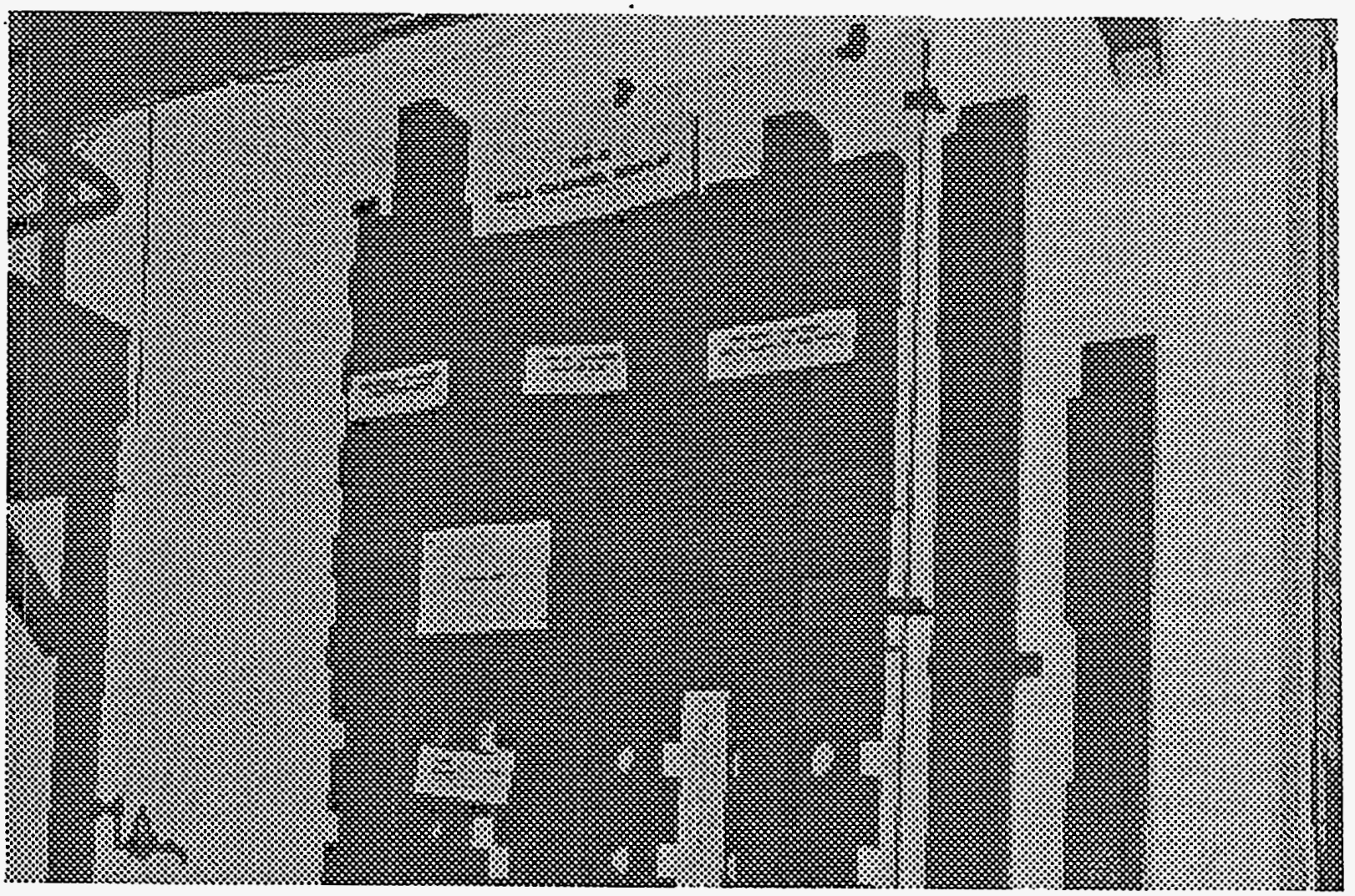

Mock-ups of $\mathrm{N}$ Reactor Ba11 $3 X$ safety system channel (above) and process channel/coolant loop (below) in the 185/189-D Building, 1980s.

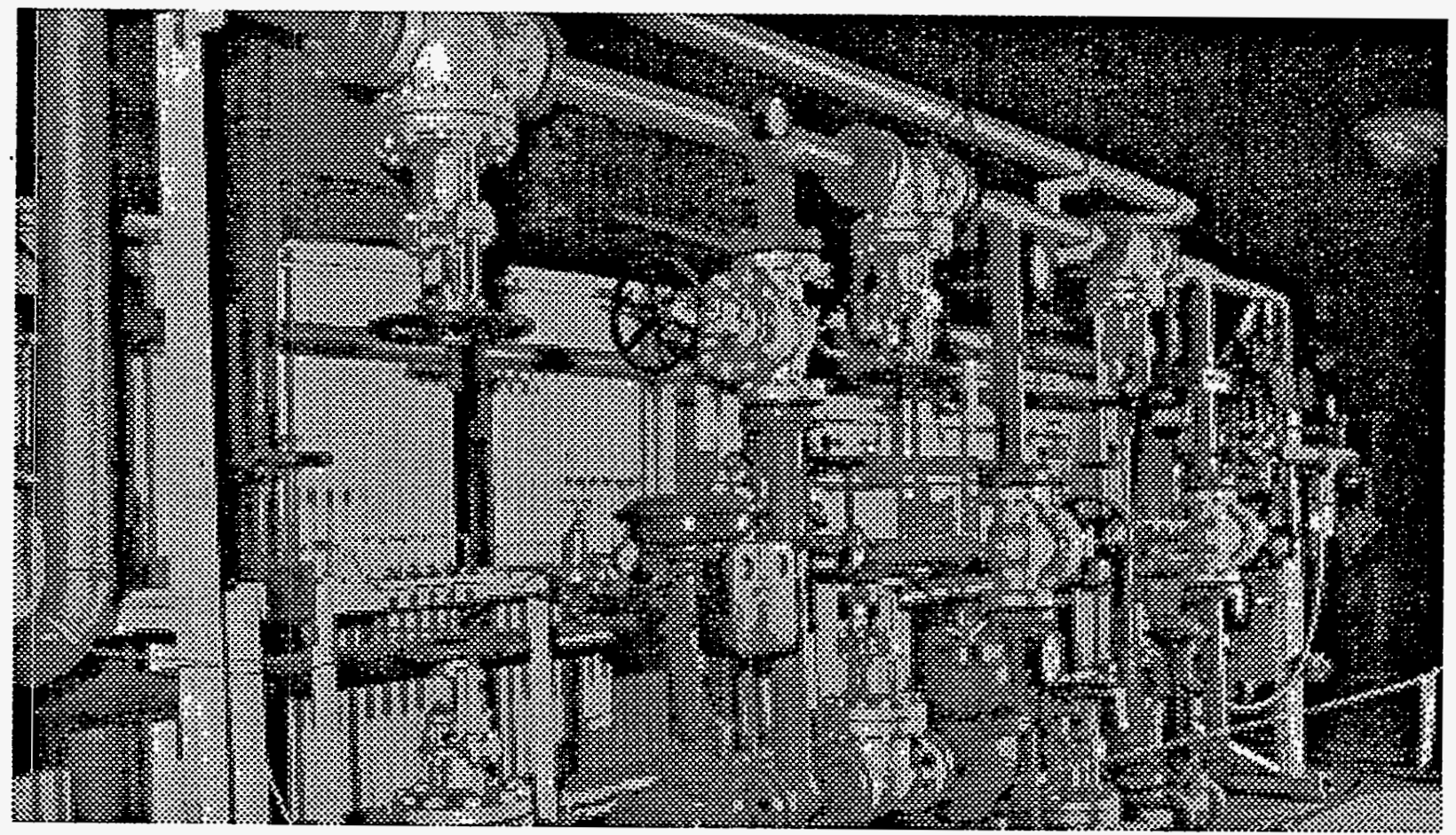


generator replacement in 1982), repair criteria for the fuel rupture monitor sample water reinjection system, and examination of the process tube flow monitor system. Additionaliy, a safety study was conducted of the boiling point suppression and high temperature emergency cooling system instrumentation and of other reactor surveillance equipment.

Another mock-up was built to test inspection and removal equipment for the graphite cooling tubes and to cut and dispose of the graphite in-core fission chamber assemblies. Acceptance test procedures were developed for-a new process tube drying system in early 1987, at about the same time as leak and flow characteristics of the reactor's $V$-il valves were evaluated against a newer design. Other trials examined the therral fatigue of $N$ Reactor fuel closures, the flow resistance of various process lines, the ultrasonic detection of various leaks, the thermal gradients in various states of standby ${ }_{\text {issues. }}$ the flush characteristics of different spacers, and many. other

During the same years, BNHL work declined in the 185/189-D Building, as there were no new orders placed by power companies for nuclear reactors during the decade. During the 1980s, some work was done in thermal modeling and simulation tests for the U.S. Department of Energy (DOE) (modern federal management agency overseeing the Hanford Site and other nuclear defense sites) Seasonal Thermal Energy Storage program, and in simulated fuel rod tests of pellet-cladding interaction in light-water reactors. ${ }^{87}$ The last project done in the 185/189-D Laboratory was a UNI endeavor to build an indoor electrical substation in the facility, complete with a transformer, circuit breaker, and incoming and outgoing sections. The project was completed in 1987. However, in February 1988, the DOE announced that $N$ Reactor, closed for repairs since January 1987, would not restart. Lacking work, the 185/189-D Building closed later in 1988 .

In 1994, the facility was nominated to the National Register of Historic Places, because of its pioneering role over many years in thermal hydraulics, flow studies, heat transfer, and other reactor coolant support work. During 1994 and 1995, it was demolished as part of a complex of six buildings (185-D, 189-D, 190-D, 190-DA, 195-D, and 1724-D), in the largest decontamination and decommissioning (D\&D) project thus far in Hanford Site history. 


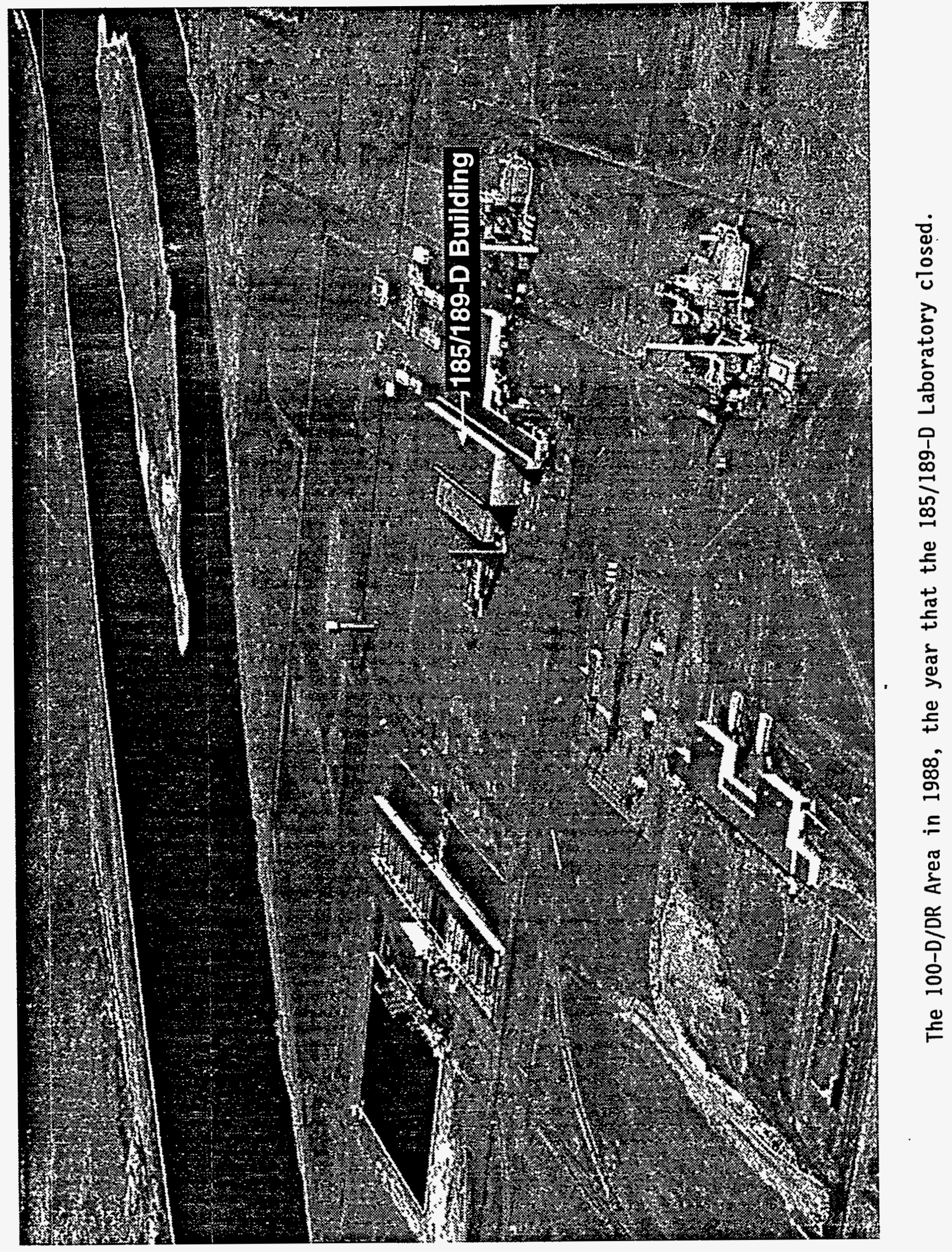




\section{WHC-MR-0465}

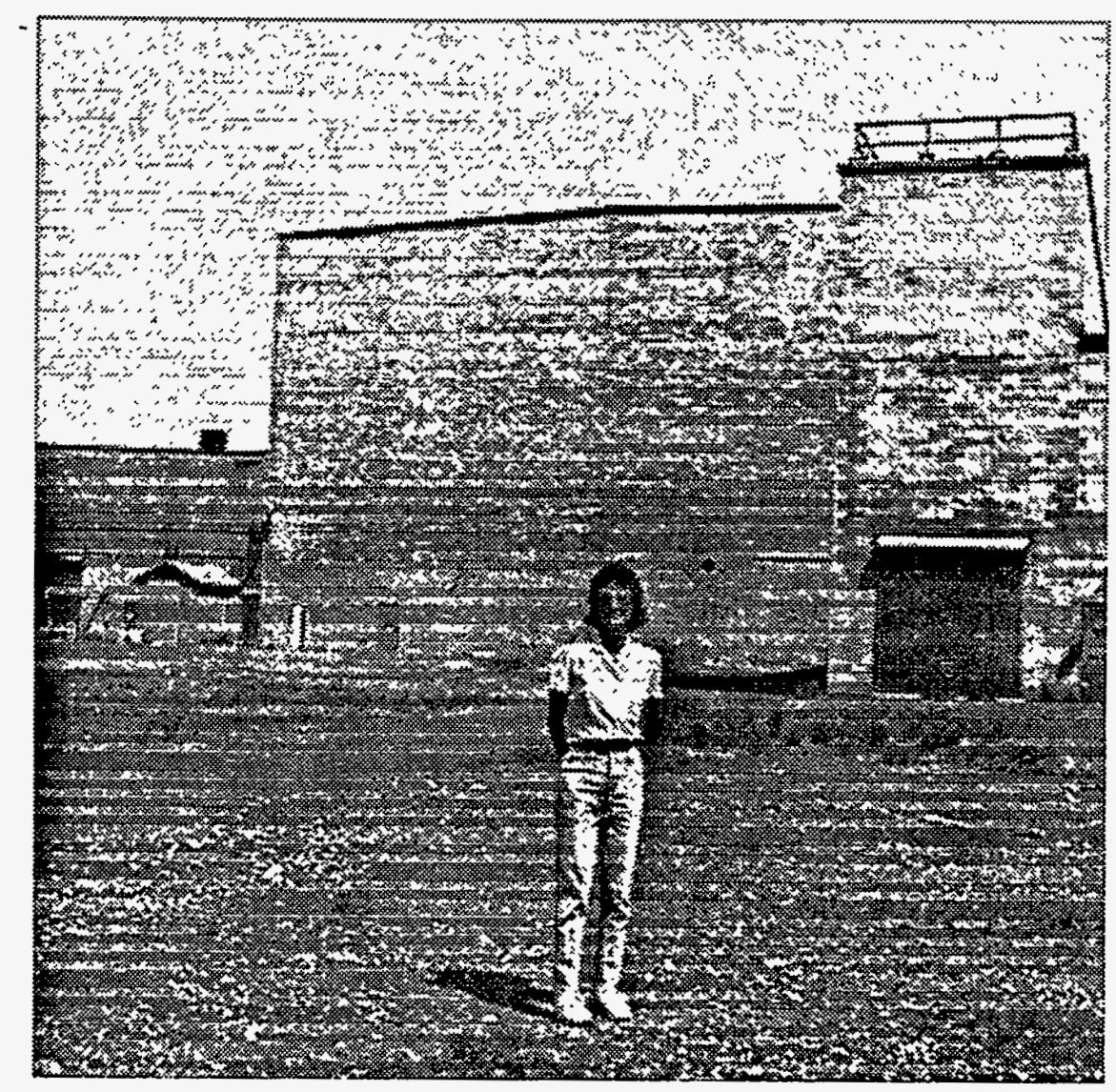

Hanford Historian Michele Gerber studies the 185/189/190-D Complex : shortiy before its demolition in 1994. 
WHC-MR-0465

This page intentionally left blank. 


\subsection{REFERENCES}

1. DuPont, HAN-10970, Book III, pp. 736-737, 747-48; and Hanford Engineer Works, OUT-1462, pp. 18, 88; and DuPont, HAN-73214, Book 14, pp. 136-137; and Reinker, HW-22110.

NOTE: The most authentic description of the physical characteristics and functions of the 189-D and 185-D Buildings can be found in DuPont, HAN-10970, Book III, pp. 736-737, 747-48; and in DuPont, HAN-73214, Book 14, pp. 136-137; and in Gerber, WHC-MR-0425, pp. 8-9.

2. Hanford Engineer Horks, OUT-1462, p. 18; and

3. DuPont, HAN-73214, Book 14, pp. 117-126; and Hanford Engineer Works, OUT-1462, pp. 78-79; and Kidder, HW-7-4444; and Con 7ey, HW-15943; and Conley, HW-20342; and Fryar, HW-23742, pp. 25-26.

4. DuPont, HAN-73214, Book 11, pp. 79, 111, 137; and HW-10475-B, pp. 1110.

5. DuPont, HAN-73214, Book 15, pp. 138-141; and Milton, HW-3-6898; and Menegus, HW-7-2744; and HW-10475-B, pp. 1110-1125; and Wende, HW-7-3486; and Wende, HW-7-3834.

6. DuPont, HAN-73214, Book 15, pp. 111-114; and Smith and Worthington, HW-3-2074; and Hanford Engineer Works, OUT-1462, p. 88.

NOTE: There were many other studies pertaining to corrosion, film formation and heat transfer at Hanford during this time period. The references shown are a tiny portion of the existing documentation.

7. Horthington, HW-7-1936; and Simon and Smith, HW-7-1948; and Wende, HW-7-2520-DEL, pp. 25, 44; and DuPont, HAN-73214, Book 15, pp. 135-137; and Jordan, $H W-7-3188$; and Jordan, $H W-7-3307$; and Jordan, $H W-7-3392$; and Jordan, HW-7-3441; and Jordan, Wende and Gast, HW-7-2984, p. 16.

8. Jordan, Hende and Gast, HW-7-2984, p. 27; and Hewlett and Anderson, The New World, pp. 482-655; and Hewlett and Duncan, Atomic Shield, pp. 1-154.

9. Jordan, HW-7-3392, p. 7; and DuPont, HAN-73214, Book 14, p. 132.

10. DuPont, HAN-72314, Book 14, p. 132; and Wende, HW-7-6311; and Woods, HW-7-6254; and Woods,-HEH-7178, p. 3; and Woods, HEH-7431, pp. 3-4; and Hoods, HEW-7597, pp. 3-4; and Woods, HW-7827, pp. 1-3; and Woods, $H W-8491$, pp. 5-6.

11. Woods, HW-7-6254; and Woods, HEW-7178, pp. 8-9.

12. Woods, HW-9005, pp. 1-2. 7; and Woods, HW-9314, pp. 1, 7-8; and Woods, HW-9955, pp. 1, 3-4; and Woods, HW-10160, pp. 5-6; and Hoods, HW-10548, p. 6; and Etheridge, HW-32664; and Pile Engineering, HW-11829, pp. 4-5; and Reinker and Johnson, HW-15295, pp. 2, 5; and Reinker and Johnson, HW-15715, p. 2; and Woods, HW-13007, p. 3.

NOTE: Additional sources exist for the 105-D and 105-F Flow Laboratories, but they are not the subject of this report. 
13. Gast, P. F., HW-13022, p. 1; and Wende, HW-13184; and Greninger, HW-15620-DEL; and Lewis, HW-19068; and Plum, PWM-542, P. 1; and Alexander, HW-19955, p. 9; and Pike, Letter to LeBaron, Apri1 1950; and Carbon and Fryar, HW-20425.

14. Windsheimer, HW-20841; and Carbon and Fryar, HW-20425; and Reinker, $\mathrm{HH}-22110$; and Woods, HH-19721, p. 2.

15. Hanford Atomic Products Operation, "Tour Guide, Contractor Replacement Program," p. 19.

16. Nelson, HW-21531, p. 4.

17. Botsford and Alexander, HW-20188, pp. 18-19; and Botsford and Alexander, $\mathrm{HW}-20406$, p. 24; and ATexander, HW-21931, p. 5; and ATexander, HW-22346, p. 9; and Alexander, HW-22886, p. 20; and Alexander, HW-23153; and Fryar, HW-23742, p. 33; and Department Managers, HW-22075-DEL, pp. 29, 32; and Miller, HW-27393, p. 17; and Fryar, HW-23361.

18. Alexander, HW-23153; and Vanderwater, HW-23251; and Carbon, HW-23669, pp. 6, 12; and Vanderwater, HW-23861; and Carbon, HW-23934; and HW-24242; and Fryar, HW-23646; and Fryar, HW-23646; and Lewis, HW-24838, p. 12.

19. Alexander, HW-24215; and Carbon, HW-24598, p. 25; and Alexander, HW-25054, pp. 9-12; and Carbon, HW-24833; and Carbon, HW-23934, p. 4; and Carbon, HH-24242, p. 5.

NOTE: Metallic "creep" is a slow deformation of the metal as the result of stress, including the stress of irradiation and/or high temperature conditions.

20. Schilson, HW-23086; and Wood, HW-23955; and Carbon, HW-23865; and Johnson, HW-24602; and Alexander, HW-24834. See also: Hanford Site Project Records for Projects CG-558, CG-600, and CG-775, al1 entitled "Reactor Plant Modifications for Increased Production."

21. Lewis and Rohrbacher, HW-29132; and Strege, HW-32960.

22. Carbon, HW-23448, p. 15; and Carbon, HW-24598, p. 9; and Carbon, $\mathrm{HW}-25053$; and WiTson, $\mathrm{HW}-28207, \mathrm{pp} .8-10$.

23. Witson, HW-28207, pp. 10-15.

24. Miller, HW-27393, p. 2 .

25. McNutt, HW-34150; and Carbon and Gilbert, HW-37437.

26. Taylor, HW-34229, pp. 6, 12, 18-19.

27. Hale, HW-24800-103, pp. 7-11; and Forsman, HW-35794, pp. 3-5.

28. Riggs, HW-22936. 
29. Greninger, HW-14110, pp. 57-62.

30. Alexander, HW-22886, p. 20; and Kreusi, Duval1 and Davenport, HW-22922, pp. 7-8; and Faulkner, Davenport and Duvall, HW-24724, pp. 7-9; and Faulkner, Davenport and Duva11, HW-27354, pp. 12-16; and Faulkner, Davenport and Duva17, HW-27636, pp. 7-10; Davenport, Faulkner and Ozeroff, HW-30508, p. 7; and Faulkner, Davenport and Duva11, HW-29596, p. 11; and Gerber, WHC-MR-0388, pp.149-151.

31. Fau7kner, Davenport and Duva11, HW-28283, pp. 12-13; and Faulkner, Davenport and Duva17, HH-28610, pp. 8-11; and Farrand and Lloyd, HW-29453; and Faulkner, Davenport and Duva11, HW-29596, pp. 11-15; and Davenport, Faulkner and 0zeroff, HW-30508, pp. 6-8; and Staff, Physics Unit, HW-31351.

32. Pile Technology Section, Engineering Department, HW-41877, pp. 30-31, 50; and Carson, Purcell and McEwen, HW-30907 RD, pp. 13-14.

33. Heacock, HW-40837.

34. Rudock, HW-37090, Rev. 1.

35. PiTe Technology Subsection, Engineering Department, HW-41877, pp. 7-8, 21-22, 30; and Robb, HW-28784; and Trumble, HW-44708, Vol. 1; and Morris, HW-44473; and Waters, HW-47197; and deHalas, HW-45045; Greager, HW-36621, p. 3; and Geier and VanWormer, HW-75609. See also: Hanford Site Project Records for Projects CG-558, CG-600 and CG-775, all entitled "Reactor Plant Modifications for Increased Production."

36. Batch and Toyoda, HW-42469-B, pp. 2-5; and Reactor and Fue7s Research and Development Operation, HW-47810, pp. 28-29.

37. McCarthy and VanHormer, HW-43464; and Lovington, HW-36224; and Carlson and Trumble, HW-63471.

38. Arneson and Vantormer, HW-41400; and Arneson, HW-41661.

39. Department Managers, HW-42219, pp. Fb-14, Fb-21.

NOTE: In most cases, removal of damaged process tubes at Hanford was accomplished with an equipment piece developed onsite and known as a tube splitter. It was an internal probe that progressively widened until the tube metal parted. Then, individual tube lengths were pulled out.

40. Be11, HW-43394.

41. McEwen, Batch, Foley, and Kreiter, HW-47892, p. 3.

42. McEwen, Batch, Foley and Kreiter, HW-47892, pp. 3-4; and Operation Managers, HW-47943, D. A-7.

43. Hesson and Thorne, HW-48519; and Pound, HW-48759; and Operation Managers, HH-49419, P. A-11; and Hesson and Thorne, HH-49813; and Operation Managers, HW-49752, p. A-9; and Batch, Hesson, Thorne and Toyoda, HW-50323; and Pound and Busse7man, HW-52340; and Batch, Hesson and 
Thorne, HW-52424-A; and Hesson and Thorne, HW-52424-B; and Toyoda and Calkin, HW-53593; and Operation Managers, HW-53299-DEL, P. A-15; and Hesson and Thorne, HW-54329.

44. VanWormer, HW-64415.

45. Operation Managers, HW-47943, pp. A-4, A-6.

46. Waters and Horn, HW-54590; and Operation Managers, HW-55162-DEL, pp. Al-19-20; and Waters, HW-55269; and Fitzsimmons and Hesson, $\mathrm{HW}-56621$; and Operation Managers, HW-56914, pp. Al-15-16; and Operation Managers, HW-57636, p. Al-15; and Operation Managers, HW-58661, p. A-14; and Operation Managers, HW-58019, p. A-16.

47. Operation Managers, HW-55162-DEL, pp. A1-20-21; and Operation Managers, $\mathrm{HW}-56914, \mathrm{p}$. A1-16; and Operation Managers, HW-60505, p. A-17; and Operation Managers, HW-57636, p. Al-16; and Operation managers, $\mathrm{HW}-58019$, p. A-17; and Operation Managers, HW-58244, p. A-16; and Batch and Toyoda, $\mathrm{HW}-65722$; and Operation Managers, HW-58661, p. A-15.

NOTE: The KER facility was a underground test facility located in the KE Reactor area. Circulation, heat transfer and other tests using radioactive materials were conducted in the KER facility.

48. Operation Managers, HW-55162-DEL, p. Al-2l; and Operation Managers, HW-56914, p. Al-16; and Lovington, HW-36224; and Carlson and Trumble, HW-62471; and Operation Managers, HW-58019, p. A-16.

49. Operation Managers, HW-59099, p. A-17; and Operation Managers, HW-59463, pp. A-16-17; and Operation managers, HW-59717, p. A-22; and Operation Managers, HW-60233-A, P. A-13; and Operation Managers, HW-60505-A, p. A-18; and Operation Managers, HW-63303, p. A-19

50. Operation Managers, HW-59099, pp. A-17-18; and Operation Managers, HW-59463, pp. A-15-17; and Operation Managers, HW-61374-A, pp. A-17-18; and Operation Managers, HW-59717, pp. A-12-13; and Operation Managers, HW-60233, pp. A-21-22; and Fitzsimmons and Hesson, HW-60287; and Operation Managers, HW-60505-A, pp. A-17-18; and Operation Managers, HW-60846, pp. A-17-18; and Operation Managers, HW-61702, pp. A-16-17; and Cremer, Fitzsimmons and Hesson, HW-61929; and Operation Managers, $\mathrm{HW}-62012-\mathrm{A}$, pp. A-17-18; and Operation Managers, HW-62587-A, pp. A-17-18; and Operation Managers, HW-62899-A, pp. A-15-17; and Operation Managers, HW-63303, pp. A-18-20; and DeNeal, DUN-6888, p. 49.

51. Operation Managers, HW-58244, p. A12; and Operation Managers, HW-59717, p. A-13; and Operation Managers, HW-60846, p. A-14. NOTE: The experiments in various fuel claddings and configurations at $\mathrm{HW}$ during these years are too numerous to include here. This is a separate topic.

52. AEC/GE Study Group, GEH-26434, pp. 3.12-3.17; and HEDL Facilities catalog (1971), pp. 309 (3 pp.). 
53. Operation Managers, HW-59099, pp. A-29-30; and Operation Managers, HW-59463, pp. A-26-27; and Operation Managers, HW-61374-A, Pp. A-33-34; and Operation Managers, HH-59717, pp. A-21-22; and Operation Managers, HW-60233, pp. A-28-29; and Operation Managers, HH-60505-A, pp. A-31-32; and Operation Managers, HW-60846, pp. A-32-33; and Operation Managers, HW-61702, pp. A-30-31; and Operation Managers, HW-62012-A, pp. A-30-31; and Operation Managers, HW-62587-A, pp. A-28-30; and Operation Managers, HW-62899-A, pp. A-27-32; and Operation Managers, HW-63303, pp. A-30.

54. Batch and Toyoda, HW-65722, pp. 12-13; and Thorne, BNWL-SA-1770.

55. Batch and Toyoda, HW-65722, pp. 3-6; Toyoda, HW-71389; and Thorne, BNWL-SA-1770; and Operation Managers, HW-63740-A, pp. A-16-17; and Operation Managers, HW-64108, Pp. A-15-16; and Geering, HW-66267; and Operation Managers, $H W-65459$, P. A-18; and Operation Managers, $H W-65854$, p. A-19; and Operation Managers, $H W-66237$, p. A-14; and Operation Managers, HW-67532, pp. A-16-17; and Operation Managers, HW-67954, p. A-17.

56. Operation Managers, HW-63740-A, pp. A-28-31; and Operation Managers, $H W-64108$, pp. A-28-34; and Operation Managers, HW-65459, p. A-26-29; and Operation Managers, $H W-65854$, P. A-29; and Operation Managers, $H W-66237$, p. A-24; and Operation Managers, HW-66644-DEL, pp. A-27-28; and Operation Managers, HW-66960-DEL, p. A-26; and Operation Managers, HW-67254, p. A-31; and Operation Managers, HW-67532, pp. A-26-27; and Operation Managers, HW-67954, pp. A-28-29.

57. Batch and Toyoda, HW-65722, pp. 6-9, 11; and Thorne, BNWL-SA-1770; and Operation Managers, HW-63740-A, pp. A-16-17; and Operation Managers, HW-64108, pp. A-14-15; and Operation Managers, HW-65459, pp. A-15-17; and Operation Managers, HW-65854, pp. A-18-20; and Haters, HW-63756 1; and Waters and Fitzsimmons, HW-67139; and Operation Managers, HW-66237, pp. A-13-14; and Operation Managers, HW-66644-DEL, pp. A-15-17; and

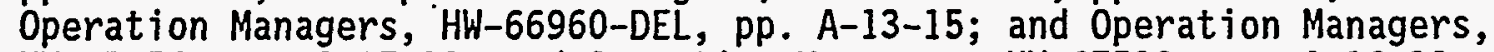
HW-67254, pp. A-17-19; and Operation Managers, HW-67532, pp. A-16-18; and Trumble, HW-84894, p. 19; and Operation Managers, HW-67954, pp. A-16-18.

58. Zaloudek, HW-68934; and Operation Managers, HW-70658-DEL, pp. A-11-12; and Operation Managers, HW-72590, pp. A-14-15; and Operation Managers, HW-82906, pp. A-14-15; and Waters, Anderson, Thorne and Batch, HW-73902 Rev; and Waters, HW-63756 4; and Operation Managers, HW-75925, p. A-15; and Section Managers, HW-76596, p. A-16; and Section Managers, HW-77397, pp. A-16-17; and Zaloudek, HW-77594; and Zaloudek, HW-79463 Rev; and Section Managers, HW-79377, pp. A-14-16; and Morris, HW-39792.

59. DeNea1, DUN-6888, pp. 21, 23, 25; and Gilbert, HW-71619 RD Rev. 4.

60. Operation Managers, HW-70658-DEL, P. A-12; and Anderson, Thorne and Batch, HW-71784; and Operation Managers, HW-72590, P. A-15; and Operation Managers, HW-82906, p. A-15; and Operation Managers, HW-75925, p. A-14; and Section Managers, HW-76596, pp. A-15-16; and Section Managers, HW-77397, p. A-17; and Anderson, Thorne and Batch, HW-77470; and Section Managers, HW-79377, pp. A-12-14. 
61. Koberg and Purce11, HW-SA-2556; and Hesson, Thorne and Batch, HW-70711; and Operation Managers, HW-70658-DEL, p. A-21-22; and Operation Managers, HW-72590, pp. A-41-42; and Hesson, Fitzsimmons, Waters and Batch, $\mathrm{HW}-73395$; and Operation Managers, HW-74522, P. A-45; and ZaToudek and Hesson, HW-76115; and Operation Managers, HW-75925, p. A-22; and Section Managers, HW-76596, p. A-25; and Hesson, Thorne and Batch, HW-70711 Rev; and Amos and Zaloudek, HW-77681; and Section Managers, HW-77397, p. A-27; and Waters and Fitzsimmons. HW-SA-3086; and Waters, Hesson, Fitzsimmons and Batch, HW-77303.

62. "Hanford To Cut Back...," p. 1, January 8, 1964; and DeNea1, DUN-6888, p. 42; and Sinclair, "Battelle-Northwest...." May 1968; Hylbak, RL-GEN-1180, Sup 1, p. 67; and Purce11, BNWL-SA-557; and Richmond and Pollock, BNWL-726.

63. Zaloudek, HW-SA-3340; and Zaloudek, HW-80535 RD; and Section managers, HW-80560, pp. A-15-16, A-25-26; and Hesson, Fitzsimmons and Batch, HW-80523 Rev 1; and Fitzsimmons, HW-80970 Rev 1; and Anderson, Batch, Thorne and Fitzsimmons, HW-80692; and Section Managers, HW-83000, pp. A-11-12, A-30-31, B-17; and Hesson, Fitzsimmons and Batch, HW-83443; and Rowe, Anderson, and Thorne, HW-84104; and Section managers, HW-84591, pp. A-7-9, A-19-20, A-37; and Han??thorne, BNWL-CC-225, Rev 1.

NOTE: The direct quotation is from Section Managers, HW-80560, p. A-25

64. Dickeman, HAN-90792 (RL-NRD-150-1), P. 24; and Anderson and Batch, DUN-8263; and Department Managers, BNWC-8-1, pp. A-7-10; and Zaloudek, BNWL-34; and Dickeman, RL-NRD-150-4, p. 19; and Pociluyko, RL-NRD-498; and Anderson, Batch, Thorne and Fitzsimmons, BNWL-CC-193; and Dickeman, HAN-92810 DEL (RL-NRD-150-9), pp. 28-19, 33; and Shoemaker, DUN-8264; and Dickeman, HAN-93378 DEL (RL-NRD-150-11), pp. 30-33.

65. Hylbak, RL-GEN-1180 Sup 1, pp. 75-79.

66. Dickeman, RL-NRD-660-1, pp. 40, 42; and BNWL-CC-500-046601, pp. 17-18, 48-49; and DUN, HAN-94154 DEL (DUN-559), pp. E-1-4; and Freshley, Wheeler, Batch and Hesson, BNWL-CC-655; and Anderson, Fitzsimmons and Thorne, BNWL-CC-729; and Fitzsimmons, Thorne and Batch, BNWL-CC-1095; and Telford, RL-GEN-1542; and Sutey, BNWL-CC-1369; and BNWL-444, pp. 29-32, 44 .

67. Shoemaker, DUN-8267; and Shoemaker, DUN-8242; and Kugler, DUN-8273; and Sutey, BNWL-CC-1534; and Sutey and Knudsen, BNWL-SA-1767.

68. McCul7ough, DUN-5806; and Wegener, DUN-6507 RD; and Zaloudek and Moulton, BNWL-CC-1989; and Newe11, DUN-8266; and Long, DUN-6327; and Stickney, DUN-6368; and Yatabe, Collingham, Hill and Thorne, BNHL-SA-2577.

69. DeNeal, DUN-6888, p. 42.

70. Solecki, DUN-6606; and Schmidt, DUN-8244; and Robinson, DUN-7066; and DUN, DUN-AP-12-HPPSS; and Flickinger and Lander, DUN-7239; and Robinson, DUN-8241; and Peters and Schmidt, DUN-7485; and DUN, DUN-AP-22-WPPSS; and Barker and Weakley, DUN-7672; and Arnold, DUN-7699; and Bainard, 
DUN-7668, Rev. 1; and Hanford Atomic Products Operation, HW-69000 Vol. 2, p. 4.3.3-2.

NOTE: The V-12 valves were three-position units that functioned to divert coolant water off of the rear risers of $N$ Reactor when maintenance work and other access to the rear area was required. They were replaced with spool pieces during 1975-1976.

71. Sutey, Fitzsimmons and Angle, BNWL-CC-2581.

72. Creer, Fitzsimmons, and Hesson, BNWL-CC-2463; and Sutey, Fitzsimmons and Collingham, BNWL-B-88.

73. Yatabe, Collingham, Hil1, McSweeney and Thorne, BNWL-1136; and Collingham, Hill, Yatabe and Thorne, BNWL-SA-3286; and Collingham, Thorne and McCormack, HEDL-TME-71-146; and Mi11hollen and Sutey, BNWL-1424.

74. Sutey, Fitzsimmons, Thorne and Torobin, BNWL-SA-3724.

75. Lander, UNI-122; and Lander, UNI-122 Add. A, p. 1.

76. Pociluyko, DUN-7432-D; and Flickinger, DUN-6576 Add 1; and Shoemaker, DUN-7073 Sup 2; and Lattin, UNI-164; and Lattin, UNI-214; and Etheridge, UNI-139; and Cummings, UNI-245; and Kratzer, UNI-70-E.2.a; and Bartlett, UNI-274; and Lander, DUN-8054; and Lander, DUN-8119; and Simsen, UNI-23; and Weed, UNI-438; and Pociluyko, UNI-466; and Pociluyko, DUN-8157; and Russe11, UNI-104; and Pociluyko, UNI-81; and Eirich, UNI-464; and Weed, UNI-373 B; and Shaw, UNI-279; and Fields and Worley, UNI-501.

77. Sutey and Rowe, BNWL-B-187; and Sutey and Rowe, BNWL-B-188; and Sutey and Rowe, BNWL-B-189; and Sutey and Stewart, BNWL-B-283; and Holkenhauer, Leonard, Sutey and Moir, BNHL-SA-4865; and Rowe, Wheeler and Fitzsimmons, BNWL-1771; and ZaToudek and Johnson, BNWL-1878.

78. Col1ingham, Yatabe, Hill and Thorne, HEDL-TME-72-23; and Asay, HEDL-MG-17, Rev. 6, pp. 65-72.

79. Erickson, UNI-565; and Erickson, Arnold and McCullough, UNI-617; and Alexander, UNI-881; and Alexander, UNI-894; and Trimble, UNI-874; and Weed and Etheridge, UNI-462; and Shoemaker and Etheridge, UNI-906 RDI Add 2; and Takasumi, UNI-725 Rev 2; and Eirich, UNI-939; and Wittekind and Toffer, UNI-1318; and Pociluyko, UNI-1331.

NOTE: Upsetting was à method of restoring elongated pressure tubes to their original length via heating and shortening.

80. Wheeler, Stewart, Cena, Rowe and Sutey, BNWL-1962; and Creer, Rowe, Bates, and Sutey, BNHL-1965; and Creer, Rowe, Bates and Sutey, BNWL-SA-6207; and Johnson, Allemann, Faletti, Fryer, and Zaloudek, BNWL-2120; and Zaloudek, Al lemann, Faletti, Johnson, Parry, Smith, Tokarz and Walter, BNWL-2122; and Johnson, Zaloudek, Fricke, Helenbrook and Bartz, BN-SA-1064; and Sutey, Zaloudek, and Bomelburg, BNWL-2301; and Stewart, Bampton, Aase and Sutey, PNL-2477; and Kreid, Creer, Bates, Quigley and Sutey, PNL-SA-7772; and Fitzsimmons, McKinnon and Sutey, BN-SA-787; and Bates, Stewart and Sutey, BN-SA-1017. 
NOTE: Laser Doppler anemometry (LDA) was/is a method of studying the flow of particles and fluids. It employed the Doppler effect (wherein the frequency of a moving light or sound source appears to change when it passes a stationary observer). LDA made use of the Doppler shift in light scattered by particles passing through a stationary laser (an improvement over older, streak and strobe photography techniques) to measure the particle velocity and, by inference, the velocity of the fluid in which the particles were suspended. Unlike many techniques based on probes, LDA did not disturb the flow being measured. The LDA measurement device used in the 185/189-D experiments recorded changes in light frequency from a reference beam, relative to beams generated by particles suspended in fluid (coolant water) as they passed rapidly through rod bundles at varying temperatures.

81. McSweeney, Thorne, Fitzsimmons and Anderson, BNWL-CC-1811.

82. Erickson, UNI-1437, Rev. 2, pp. 5-6, 10, V-1.

83. Scott, UNI-1960, pp. 1-3, 13-17; and Newby and Marsha71, UNI-2109; and Lyon, UNI-2110.

84. NeTson, UNI-3329; and NeTson, UNI-3422; and ZaToudek and Ruff, UNI-3653 (PNL-5924); and Zaloudek and Ruff, UNI-3994 (PNL-5930); and Lee, UNI-4193; and Nelson, UNI-4191 Rev. 1; and Alzheimer and Gonzalez, UNI-4285; and Martek, UNI-4263.

85. Pociluyko, UNI-M-87, pp. 3-8.

86. Lyon, UNI-1986; and Cummings, UNI-2063; and Rainey, UNI-2182; and Conn, UNI-2227 Rev. 1; and DeMaria, UNI-3481 Rev. 1; and Shoemaker and Fuller, UNI-2016; and Reeves, UNI-610 Rev. 1; and Leche1t, UNI-2925; and Lattin, UNI-3333; and Rasmussen, UNI-3583; and Stauch, UNI-4210; and Linschooten, UNI-4148; and Pope, UNI-4239; and Smith, UNI-4253; and Sullivan, UNI-4225.

87. Kannberg, PNL-4281 Vols. I and II; and Barner, Fitzsimmons, Lanning and Williford, PNL-SA-11651; and Barner and Fitzsimmons, PNL-5245 (NUREG/CR-3999).

88. Walker, UNI-4214 Rev. I; and Sivula and Whitney, "Cold Standby...", February 17, 1988. 


\subsection{BIBLIOGRAPHY}

AEC/GE, 1964, Catalog of Hanford Buildings and Facilities, GEH-26434, U.S. Atomic Energy Commission, Richland, Washington.

Alexander, H. K., 1951, 100 Areas Technical Activities Report, Engineers, December 1950, HW-19955, G.E. Hanford Company, Richland, Washington.

Alexander, H. K., 1951, Technical Activities Report - Heat, Water and Hechanical Studies, HW-21931, G.E. Hanford Company, Richland, Washington.

Alexander, W. K., 1951, Technical Activities Report - Heat, Water and Mechanical Studies, HW-22346, G.E. Hanford Company, Richland, Washington.

Alexander, H. K., 1951, Technical Activities Report - Heat, Water and Mechanical Studies, HW-22886, G.E. Hanford Company, Richland, Washington.

Alexander, W. K., 1952, Technical Activities Report - Heat, Water and Mechanical Studies - December 1951, HW-23153, G.E. Hanford Company, Richland, Washington.

Alexander, W. K., 1952, Technical Activities Report - Mechanical Development Studies - April 1952, HW-24215, G.E. Hanford Company, Richland, Washington.

Alexander, W. K., 1952, Technical Activities Report - Mechanical Development Studies - June 1952, HW-24834, G.E. Hanford Company, Richl and, Washington.

Alexander, H. K., 1952, Technical Activities Report - Mechanical Development Studies - July 1952, HW-25054, G.E. Hanford Company, Richl and, Washington.

Alexander, W. K., 1977, Effects of Upsetting on the Physical Properties of Zircaloy Pressure Tubes, UNI-894, United Nuclear Industries, Inc., Richland, Washington.

Alexander, H. K., 1977, Status of the Tube Elongation Problem as of July 1977, UNI-881, United Nuclear Industries, Inc., Richland, Washington.

Alzheimer, J. M., and L. M. Gonzalez, 1987, Controlled Development Plan for Development of $N$ Reactor Horizontal Control Rod Channel Profiling Equipment, UNI-4285, United Nuclear Industries, Inc., Richland, Washington.

Amos, D. E., and F. R. Zaloudek, 1963, Temperature Distribution in Long Cylindrical Fuel Elements Cooled Internal7y by Several Channels, HW-77681, G.E. Hanford Company, Richland, Washington.

Anderson, J. K., W. L. Thorne, and J. M. Batch, 1961, NPR Boiling Burnout Experiments - Preliminary Analysis, HW-71784, G.E. Hanford Company, Richland, Washington. 
Anderson, J. K., W. L. Thorne, and J. M. Batch, 1963, Burnout Heat Fluxes for NPR Tune-In-Tube Fuel Elements, HW-77470, G.E. Hanford Company, Richland, Washington.

Anderson, J. K., J. M. Batch, W. L. Throne, and D. E. Fitzsimmons, 1964, Thermal and Hydraulic Characteristics of an N-Reactor Fuel Column, HW-80692, G.E. Hanford Company, Richland, Washington.

Anderson, J. K., J. M. Batch, W. L. Thorne, and D. E. Fitzsimmons, 1965, Effects of Interjunction Flow on Thermal and Hydraulic Characteristics of an N-Reactor Fuel Column, BNWL-CC-193, Battelle Northwest Laboratories, Richland, Washington.

Anderson, J. K., and J. M. Batch, 1965, N-Reactor Fuel Element Plugging Experiments, DUN-8263, Battelle Northwest Laboratories, Richland, Hashington.

Anderson, J. K., D. E. Fitzsimmons, and W. L. Thorne, 1966, Burnout Heat Fluxes for $N$-Reactor Single-Tube Fuel Elements, BNWL-CC-729, Battelle Northwest Laboratories, Richland, Washington.

Arneson, S. 0., and F. W. VanWormer, 1956, Development Test 105-623A: Relation Between Hand and Flow Seating of STug Charges as They Affect Slug Rupture Rates, HW-41400, G.E. Hanford Company, Richland, Washington.

Arneson, S. 0., 1956, Slug Cocking and Column Bowing Experiments, HW-41661, G.E. Hanford Company, Richland, Washington.

Arnold, D. F., 1971, Design Criteria: N Zone Temperature Monitoring System Replacement, DUN-7699, Douglas United Nuclear Inc., Richland, Washington.

Asay, 0. H., 1983, HEDL Facilities Catalog, 300 Area, HEDL-MG-17, Rev. 6, Hanford Engineering Development Laboratory, Richland, Washington.

Bainard, H. D., 1971, Design Criteria: N Reactor Control Rod Coolant Recirculation Facilities, DUN-7668, Rev. 1, Douglas United Nuclear, Inc., Richland, Washington.

Barker, C. R., and E. A. Weakley, 1971, Study of 2" Grayloc Hubs Used in N-Reactor, DUN-7672, Douglas United Nuclear, Inc., Richland, Washington.

Barner, J. 0., D. E. Fitzsimmons, D. D. Lanning, and R. E. Williford, 1983, Ex-Reactor PCI Experiments, PNL-SA-11651, Pacific Northwest Laboratory, Richland, Washington.

Barner, J. 0., and D. E. Fitzsimmons, 1985, Electrically Heated Ex-Reactor Pellet-Cladding Interaction (PCI) Simulations Utilizing Irradiated Zircaloy C7adding, PNL-5245, NUREG/CR-3999, Pacific Northwest Laboratory, Richland, Washington.

Bartlett, R. J., 1974, Production Test N-371: Testing of Boiling Point Suppression Equipment Capability for Providing Low Pressure Protection, UNI-274, United Nuclear Industries, Inc., Richland, Hashington. 
Batch, J. M., G. M. Hesson, W. L. Thorne, and K. G. Toyoda, 1957, Interim Report on Tests Simulating the Transient Response of Individual Process Tubes to Inadvertent Plugging, HW-50323, G.E. Hanford Company, Richland, Washington.

Batch, J. M., G. M. Hesson, and W. L. Thorne, 1957, Results of Experimental Tests Simulating Sudden Plugging of a BDF Process Tube, HW-52424-A, G.E. Hanford Company, Richland, Washington.

Batch, J. M., and K. G. Toyoda, 1960, Description of the Therma7 Hydraulics Laboratory at Hanford, HW-65722, G.E. Hanford Company, Richland, Washington.

Bates, J. M., C. H. Stewart, and A. M. Sutey, 1979, Experimental Study of Single-Phase Flow Fields Around Steam Generator Tube Support Plates, BN-SA-1017, Pacific Northwest Laboratory, Richland, Washington.

Be17, K. J., 1956, Flow Test - CG 482 "DR Type" Rear Pigtail with B, D, DR and F Pile Fittings, HW-43394, G.E. Hanford Company, Richland, Washington.

BNWL, 1965, Batte77e-Northwest Monthly Activities Report, January 1965, BNWC-8-1, Department Managers, Battelle Northwest Laboratories, Richland, Washington.

BNWL, 1966, Pacific Northwest Laboratory Month7y Activities Report, January 1966, BNWL-CC-500-046601, Battelle Northwest Laboratories, Richland, Washington.

BNWL, 1967, Pacific Northwest Laboratory Monthly Activities Report, May 1967, BNWL-440, Battelle Northwest Laboratories, Richland, Washington.

Botsford, C. W., and W. K. Alexander, 1951, 100 Areas Technical Activities Report, Engineers, January 1951, HW-20188, G.E. Hanford Company, Richland, Washington.

Botsford, C. W., and W. K. Alexander, 1951, 100 Areas Technical Activities Report, Engineers, February 1951, HW-20406, G.E. Hanford Company, Richland, Washington.

Carbon, M. H., and R. M. Fryar, 1951, Pile Modifications Resulting in Increased Power Leve7s, HW-20425, G.E. Hanford Company, Richland, Washington.

Garbon, M. H., 1952, Possible Water Flow Rates at DR and H Piles, HW-23865, G.E. Hanford Company, Richland, Washington.

Carbon, M. W., 1952, Technical Activities Report, Heat Transfer Studies, January 1952, HW-23448, G.E. Hanford Company, Richland, Washington.

Carbon, M. W., 1952, Technical Activities Report, Heat Transfer Studies, HW-23669, G.E. Hanford Company, Richland, Washington. .

Carbon, M. W., 1952, Technical Activities Report, Heat Transfer Studies, HW-23934, G.E. Hanford Company, Richland, Washington. 
Carbon, M. H., 1952, Technical Activities Report, Heat Transfer Studies, HW-24242, G.E. Hanford Company, Richland, Washington.

Carbon, M. H., 1952, Technical Activities Report, Heat Transfer Studies, HW-24598, G.E. Hanford Company, Richl and, Washington.

Carbon, M. W., 1952, Technical Activities Report, Heat Transfer Studies, HW-24833, G.E. Hanford Company, Richland, Washington.

Carbon, M. H., 1952, Technical Activities Report, Heat Transfer Studies, HW-25053, G.E. Hanford Company, Richland, Washington.

Carbon, M. W., and H. D. Gilbert, 1955, Tube Power Limits - Past, Present and Future, HW-37437, G.E. Hanford Company, Richland, Washington.

Carlson, P. A., and R. E. Trumble, 1959, Preliminary Hazards Review, Operational Charge-Discharge for Hanford Reactors, HW-62471, G.E. Hanford Company, Richland, Washington.

Carson, A. B., R. H. Purcell, and L. H. McEwen, 1954, Economic Evaluation of Recirculation as a Method of Pile Cooling, HW-30907 RD, G.E. Hanford Company, Richland, Washington.

Collingham, R. E., V. R. Hill, J. M. Yatabe, and H. L. Thorne, 1970, Development and Results of an Electrically Heated Seven-Pin Bundle Assemb7y for Thermal Hydraulic Testing in Liquid Metals, BNWL-SA-3286, Battelle Northwest Laboratories, Richland, Washington.

Collingham, R. E., W. L. Thorne, and J. D. McCormack, 1971, 217-Pin WireWrapped Bundle Coolant Mixing Test, HEDL-TME-71-146, Hanford Engineering Development Laboratory, Richland, Washington.

Collingham, R. E., J. M. Yatabe, V. R. Hi11, and W. L. Thorne, 1972, Experimental Temperature Distributions in Liquid Metal Fast Breeder Reactor Fuel Assemblies, the Effect of Bowing Distortions, HEDL-TME-72-23, Hanford Engineering Development Laboratory, Richland, Washington.

Conley, W. R., 1950, Final Report: Production Test 105-214-P: Silica Feed E7imination, HW-15943, G.E. Hanford Company, Richland, Washington.

Conley, W. R., 1951, A Review of Water Treatment Technology as Applied in the 100 Areas, Hanford Works, HW-20342, G.E. Hanford Company, Richland, Washington.

Conn, K. R., 1983, Technical Criteria - Project H-601G Rep7acement Valves, UNI-2227, Rev. 1, United Nuclear Industries, Inc., Richland, Washington.

Creer, J. M., D. E. Fitzsimmons, and G. M. Hesson, G.M., 1970, Pressure Losses in An N-Reactor Fuel Column, BNWL-CC-2463, Battelle Northwest Laboratories, Richland, Washington. 
Creer, J. M., D. S. Rowe, J. M. Bates, and A. M. Sutey, 1976, Effects of Sleeve B7ockages on Axial Velocity and Intensity of Turbulence in an Unheated $7 X 7$ Rod Bundle, BNWL-1965, Battelle Northwest Laboratories, Richland, Washington.

Creer, J. M., D. S. Rowe, J. M. Bates, and A. M. Sutey, 1977, Turbulent Flow in a Model Nuclear Fuel Rod Bundle Containing Partial Flow Blockages, BNWL-SA-6207, Batte17e Northwest Laboratories, Richland, Washington.

Cremer, B. R., D. E. Fitzsimmons, and G. M. Hesson, 1959, Resu7ts of Tests Investigating Panel7it Protection to " $C$ " and " $K$ " Process Tubes Without Rear Pigtail, HW-61929, G.E. Hanford Company, Richland, Washington.

Cummings, J. E., 1982, Production Tests N-520, V-19/V-3 Split Flow Testing, UNI-2063, United Nuclear Industries, Inc., Richland, Washington.

Cummings, K. N., 1974, N Reactor Graphite-Shield Cooling System Safety Analysis Report, UNI-245, United Nuclear Industries, Inc., Richland, Washington.

Davenport, D. E., J. E. Faulkner, and J. Ozeroff, 1954, Quarterly Report Physics Unit, October, November, December 1953, HW-30508, G.E. Hanford Company, Richland, Washington.

deHalas, D. R., 1956, Reduction of the Amount of Dichromate Added to Pile Cooling Water, Final Report, PT-105-542-E, HW-45045, G.E. Hanford Company, Richi and, Washington.

DeMaria, L. C., 1986, Project Management Plan, V-II Valve Rehabilitation Project H-680, UNI-2481, Rev. 1, United Nuclear Industries, Inc., Richland, Washington.

DeNeal, D. H., 1970, Historical Events - Single-Pass Reactors and Fuels Fabrication, DUN-6888, Douglas United Nuclear Inc., Richland, Washington.

Dickeman, R. L., 1965, N-Reactor Department Monthly Report - January 1965, HAN-90792, RL-NRD-150-1, G.E. Hanford Company, Richland, Washington.

Dickeman, R. L., 1965, N-Reactor Department Month7y Report - May 1965, RL-NRD-150-4, G.E. Hanford Company, Richland, Washington.

Dickeman, R. L., 1965, N-Reactor Department Month7y Report - September 1965, HAN-92810-DEL, RL-NRD-150-9, G.E. Hanford Company, Richland, Washington.

Dickeman, R. L., 1965, N-Reactor Department Month7y Report - November 1965, HAN-93379-DEL, RL-NRD-150-11, G.E. Hanford Company, Richland, Washington.

Dickeman, R. L., 1966, N-Reactor Department Month7y Report - January 1966, RL-NRD-660-1, G.E. Hanford Company, Rich7and, Washington.

DUN, 1966, Douglas United Nuclear, Inc., Monthly Report, February 1966, HAN-94154-DEL, DUN-559, Douglas United Nuclear, Inc., Richland, Washington. 
DUN, 1970, Thermal Hydraulics, DUN-AP-12-WPPSS, Douglas United Nuclear, Inc., Richland; Washington.

DUN, 1971, Orificing Study, DUN-AP-22-WPPSS, Douglas United Nuclear, Inc., Richland, Washington.

duPont, 1945, Construction of Hanford Engineer Horks: History of the Project, HAN-10970, Book III, E. I. duPont de Nemours and Company, Wilmington, Delaware.

duPont, 1946, Operations of Hanford Engineer Works, HAN-72314, Books 11, 14, and 15, E. I. duPont de Nemours and Company, Wilmington, Delaware.

Eirich, A. J., 1975, Development Test No. 401, Process Tube Elongation Prototype Equipment Test, UNI-464, United Nuclear Industries, Inc., Richland, Washington.

Eirich, A. J., 1978, Development Test No. N-436, Process Tube Drag Heasurements, UNI-939, United Nuclear Industries, Inc., Richland, Washington.

Erickson, G. L., 1976, Backup Fuel Cladding Failure Monitor, Feasibility Study, UNI-565, United Nuclear Industries, Inc., Richland, Washington.

Erickson, G. L., D. F. Arnold, and J. D. McCullough, 1976, Functional Design Criteria, 105-N Flow-Temperature Data Logger Visual Display and A7arms," UNI-617, United Nuclear Industries, Inc., Richland, Washington.

Erickson, G. L., 1982, Development and Quality Assurance Instructions and Procedures for Systems and Equipment Development Section, UNI-1437, Rev. 2, United Nuclear Industries, Inc., Richland, Washington.

Etheridge, E. L., 1954, Preliminary Tests Results of Unfiltered River Water As a Pile Coolant, HW-32664, G.E. Hanford Company, Richland, Washington.

Etheridge, E. L., 1974, Preliminary Engineering Study: Conversion of N Reactor Shield Cooling System to Recirculation, UNI-139, United Nuclear Industries, Inc., Richland, Washington.

Farrand, H. B., and R. C. Lloyd, 1953, Multiplication of Enriched Loading in Exponential Pile, HW-29453, G.E. Hanford Company, Richland, Washington.

Faulkner, J. E., D. E. Davenport, and G. E. Duval1, 1952, Technical Activities Report - Physics, May 1952, HW-24724, G.E. Hanford Company, Richland, Washington.

Faulkner, J. E., D. E. Davenport, and G. E. Duval1, 1953, Technical Activities Report for February 1953, Physics Unit, Applied Research Sub-Section, HW-27354, G.E. Hanford Company, Richland, Washington.

Faulkner, J. E., D. E. Davenport, and G. E. Duval1, 1953, Technical Activities Report for March 1953, Physics Unit, Applied Research Sub-Section, HW-27636, G.E. Hanford Company, Richland, Washington. 
Faulkner, J. E., D. E. Davenport, and G. E. Duval1, 1953, Technical Activities Report for May 1953, Physics Unit, Applied Research Sub-Section, HW-28283, G.E. Hanford Company, Richland, Washington.

Faulkner, J. E., D. E. Davenport, and G. E. Duva11, 1953, Technical Activities Report for June 1953, Physics Unit, Applied Research Sub-Section, HW-28610, G.E. Hanford Company, Richland, Hashington.

Faulkner, J. E., D. E. Davenport, and G. E. Duval1, 1953, Technical Activities Report for September 1953, Physics Unit, Applied Research Sub-Section, HW-29596, G.E. Hanford Company, Richland, Washington.

Fields, K. E., and R. H. Worley, 1975, 1976 V-12 Valve Replacement Program, UNI-501, United Nuclear Industries, Inc., Richland, Washington.

Fitzsimmons, D. E., and G. M. Hesson, 1958, Experimental Results of Tests Simulating Plugging of a $K$ Tube with I\&E Elements, HW-56621, G.E. Hanford Company, Richland, Washington.

Fitzsimmons, D. E., and G. M. Hesson, 1959, Interim Report on Laboratory Experiments Investigating Consequences of Failure of Front Hydraulic Fittings in "C" OCD Geometry, HW-60287, G.E. Hanford Company, Richland, Washington.

Fitzsimmons, D. E., 1964, Two-Phase Pressure Drop in Piping Components, HW-80970, Rev. 1, G.E. Hanford Company, Richland, Washington.

Fitzsimmons, D. E., W. L. Thorne, and J. M. Batch, 1967, Experimental Determination of the Departure from Nucleate Boiling in Large Rod Bundles at High Pressure, BNWL-CC-1095, Battelle Northwest Laboratories, Richland, Washington.

Fitzsimmons, D. E., M. A. Mckinnon, and A. M. Sutey, 1979, Nuclear Fuel Pin Simulator for LOCA-Related Zircaloy Oxidation Studies, BN-SA-787, Pacific Northwest Laboratories, Richland, Washington.

Flickinger, J. K., 1975, Design Criteria, Process Tube Flow Monitoring Tubing Replacement, DUN-6576, Addendum 1, Douglas United Nuclear, Inc., Richland, Washington.

Forsman, M. E., 1955, Time Response of a Process Tube Temperature Monitor, HW-35794, G.E. Hanford Company, Richland, Hashington.

Freshley, M. D., R. G. Wheeler, J. M. Batch, and G. M. Hesson, 1966, Investigation of the Combined Failure of a Pressure Tube and a Defected Fuel Rod in PRTR, BNWL-CC-655, Battelle Northwest Laboratories, Richland, Washington.

Fryar, R. M., 1952, Proposed Treatment Process for 100 Area Water Plants, HW-23742, G.E. Hanford Company, Richland, Washington.

Fryar, R. M., 1952, Technical Activities Report, Water Studies, January 1952, HW-23361, G.E. Hanford Company, Richland, Washington. 
Fryar, R. M., 1952, Technical Activities Report, Water Studies, February 1952, HW-23646, G.E. Hanford Company, Rich7and, Washington.

Gast, P. F., 1949, 100 Areas Technical Activities Report - Physics, February 1949, HW-13022, G.E. Hanford Company, Richland, Washington.

G.E., 1948, 100 Areas Technical Activities Report - Engineering, October 1948, HW-11829, Pile Engineering, G.E. Hanford Company, Richland, Washington.

G.E., 1951, Hanford Works Month7y Report for August 1951, HW-22075-DEL, Department Managers, G.E. Hanford Company, Richland, Washington.

G.E., 1954, Quarterly Report - Physics Unit, January, February, March 1954, HW-31351, Staff, Physics Unit, G.E. Hanford Company, Richland, Washington.

G.E., 1956, Pile Technology Section Annual Report for 1955, HW-41877, Pile Technology Section, Engineering Department, G.E. Hanford Company, Richland, Washington.

G.E., 1957, Hanford Laboratories Operation Monthly Activities Report, January 1957, HW-47943-DEL, Operation Managers, G.E. Hanford Company, Richland, Hashington.

G.E., 1957, Hanford Laboratories Operation Monthly Activities Report, March 1957, HW-49419-DEL, Operation Managers, G.E. Hanford Company, Richland, Washington.

G.E., 1957, Hanford Laboratories Operation Monthly Activities Report, Apri7 1957, HW-49742-DEL, Operation Managers, G.E. Hanford Company, Richl and, Washington.

G.E., 1957, Hanford Laboratories Operation Monthly Activities Report, October 1957, HW-53299-DEL, Operation Managers, G.E. Hanford Company, Richland, Washington.

G.E., 1957, Reactor and Fuels Research and development Monthly Report for December 1956, HW-47810, Reactor and Fuels Research and Development Operation, G.E. Hanford Company, Richland, Washington.

G.E., 1958, Hanford Laboratories Operation Monthly Activities Report, February 1958, HW-55162-DEL, Operation Managers, G.E. Hanford Company, Richl and, Washington.

G.E., 1958, Hanford Laboratories Operation Monthly Activities Report, Ju7y 1958, HW-56914, Operation Managers, G.E. Hanford Company, Richland, Washington.

G.E., 1958, Hanford Laboratories Operation Monthly Activities Report, September 1958, HW-57636, Operation Managers, G.E. Hanford Company, Richland, Hashington. 
G.E., 1958, Hanford Laboratories Operation Monthly Activities Report, October 1958, HW-58019, Operation Managers, G.E. Hanford Company, Richland, Washington.

G.E., 1958, Hanford Laboratories Operation Monthly Activities Report, November 1958, HW-58244, Operation Managers, G.E. Hanford Company, Richland, Washington.

G.E., 1959, Hanford Laboratories Operation Monthly Activities Report, December 1958, HW-58661, Operation Managers, G.E. Hanford Company, Richland, Hashington.

G.E., 1959, Hanford Laboratories Operation Monthly Activities Report, January 1959, HH-59099, Operation Managers, G.E. Hanford Company, Richland, Washington.

G.E., 1959, Hanford Laboratories Operation Monthly Activities Report, February 1959, HW-59463, Operation Managers, G.E. Hanford Company, Richland, Washington.

G.E., 1959, Hanford Laboratories Operation Monthly Activities Report, March 1959, HW-59717, Operation Managers, G.E. Hanford Company, Richland, Washington.

G.E., 1959, Hanford Laboratories Operation Monthly Activities Report, Apri 7 1959, HW-60233, Operation Managers, G.E. Hanford Company, Richland, Washington.

G.E., 1959, Hanford Laboratories Operation Honthly Activities Report, May 1959, HW-60505, Operation Managers, G.E. Hanford Company, Richland, Washington.

G.E., 1959, Hanford Laboratories Operation Monthly Activities Report, June 1959, HW-60846-DEL, Operation Managers, G.E. Hanford Company, Richland, Washington.

G.E., 1959, Hanford Laboratories Operation Monthly Activities Report, Ju7y 1959, HW-61374-A, Operation Managers, G.E. Hanford Company, Richland, Washington.

G.E., 1959, Hanford Laboratories Operation Monthly Activities Report, August 1959, HW-61702, Operation Managers, G.E. Hanford Company, Richland, Washington.

G.E., 1959, Hanford Laboratories Operation Monthly Activities Report, September 1959, HW-62012, Operation Managers, G.E. Hanford Company, Richland, Washington.

G.E., 1959, Hanford Laboratories Operation Monthly Activities Report, October 1959; HW-62587, Operation Managers, G.E. Hanford Company, Richland, Washington. 
G.E., 1959, Hanford Laboratories Operation Monthiy Activities Report, November 1959, HW-62899, Operation Managers, G.E. Hanford Company, Richland, Washington.

G.E., 1960, Hanford Laboratories Operation Monthly Activities Report, December 1959, HW-63303, Operation Managers, G.E. Hanford Company, Richland, Washington.

G.E., 1960, Hanford Laboratories Operation Monthly Activities Report, January 1960, HW-63740, Operation Managers, G.E. Hanford Company, Richland, Washington.

G.E., 1960, Hanford Laboratories Operation Monthly Activities Report, February 1960, HW-64108, Operation Managers, G.E. Hanford Company, Richland, Washington.

G.E., 1960, Hanford Laboratories Operation Monthly Activities Report, May 1960, HW-65459, Operation Managers, G.E. Hanford Company, Richland, Washington.

G.E., 1960, Hanford Laboratories Operation Monthly Activities Report, June 1960, HW-65854-DEL, Operation Managers, G.E. Hanford Company, Richland, Washington.

G.E., 1960, Hanford Laboratories Operation Month7y Activities Report, Ju7y 1960, HW-66237, Operation Managers, G.E. Hanford Company, Richland, Washington.

G.E., 1960, Hanford Laboratories Operation Monthly Activities Report, August 1960, HW-66644-DEL, Operation Managers, G.E. Hanford Company, Richland, Washington.

G.E., 1960, Hanford Laboratories Operation Monthly Activities Report, September 1960, HW-66960-DEL, Operation Managers, G.E. Hanford Company, Richland, Washington.

G.E., 1960, Hanford Laboratories Operation Month7y Activities Report, October 1960, HW-67254, Operation Managers, G.E. Hanford Company, Richland, Washington.

G.E., 1960, Hanford Laboratories Operation Monthly Activities Report, November 1960, HW-67532, Operation Managers, G.E. Hanford Company, Richland, Washington.

G.E., 1961, Hanford Laboratories Operation Month7y Activities Report, December 1960, HW-67954, Operation Managers, G.E. Hanford Company, Richland, Washington.

G.E., 1961, Hanford Laboratories Operation Month7y Activities Report, JuTy 1961, HW-70658-DEL, Operation Managers, G.E. Hanford Company, Richland, Washington. 
G.E., 1962, Hanford Laboratories Operation Monthly Activities Report, January 1962, HW-72590, Operation Managers, G.E. Hanford Company, Richland, Washington.

G.E., 1962, Hanford Laboratories Operation Monthly Activities Report, JuTy 1962, HW-74522, Operation Managers, G.E. Hanford Company, Richland, Washington.

G.E., 1963, 100-N Technical Manual, Volume 2: Systems Descriptions, HW-69000, Vo1. 2, Hanford Atomic Products Operation, G.E. Hanford Company, Richland, Hashington.

G.E., 1963, Hanford Laboratories Operation Month7y Activities Report, December 1962, HW-75925, Operation Managers, G.E. Hanford Company, Richland, Washington.

G.E., 1963, Hanford Laboratories Operation Monthly Activities Report, February 1963, HW-76596, Section Managers, G.E. Hanford Company, Richland, Washington.

G.E., 1963, Hanford Laboratories Operation Month7y Activities Report, Apri7 1963, HW-77397, Section Managers, G.E. Hanford Company, Richland, Washington.

G.E., 1963, Hanford Laboratories Operation Monthly Activities Report, October 1963, HW-79377., Section Managers, G.E. Hanford Company, Richland, Washington.

G.E., 1964, Hanford Laboratories Operation Monthly Activities Report, January 1964, HW-80560, Section Managers, G.E. Hanford Company, Richland, Washington.

G.E., 1964, Hanford Laboratories Operation Month7y Activities Report, June 1964, HW-83000, Section Managers, G.E. Hanford Company, Richland, Hashington.

G.E., 1964, Tour Guide, Contractor Replacement Program, Hanford Atomic Products Operation, G.E. Hanford Company, Richland, Washington.

G.E., 1965, Hanford Laboratories Operation Monthly Activities Report, December 1964, HW-84591, Section Managers, G.E. Hanford Company, Richl and, Washington.

Geering, G. T., 1960, Testing of Zircaloy-2-Clad Uranium Seven-Rod Fuel Elements, HW-66267, G.E. Hanford Company, Richland, Washington.

Geier, R. G., and F. W. VanWormer, 1962, Water Treatment Program - 07d Reactors, HW-75609, G.E. Hanford Company, Richland, Washington.

Gerber, M. S., 1993, Manhattan Project Buildings and Facilities at the Hanford Site: A Construction History, WHC-MR-0425, Westinghouse Hanford Company, Richland, Washington. 
Gilbert, H. D., 1962, Technical Specifications, Hanford Production Reactors, HW-71619 RD, Rev. 4, G.E. Hanford Company, Richland, Washington.

Greager, 0. H., 1955, Recommendations by Advisory Council on Reactor Safeguards, HW-36621, G.E. Hanford Company, Richland, Washington.

Greninger, A. B., 1949, Proposal for Laboratory Facilities in the Technical Center, HW-14110, G.E. Hanford Company, Richland, Washington.

Greninger, A. B., 1950, Review of the MD/T Program, HW-15620-DEL, G.E. Hanford Company, Richland, Hashington.

HaTe, G. R., 1957, Completion Report, Project CA-512, Volume I: 100-K Reactor Plants, HW-24800-103, Vol. I, G.E. Hanford Company, Richland, Washington.

Hanthorne, H. E., 1967, Final Safety Analysis: High Temperature Lattice Test Reactor, BNWL-CC-225, Rev. 1, Battelle Northwest Laboratories, Richland, Washington.

Heacock, H. W., 1956, Adaptation of Recirculating Water System to 100-H Area: Interim Feasibility Report, HW-40837-DEL, G.E. Hanford Company, Richland, Washington.

HEDL, 1971, HEDL Facilities Catalog, Hanford Engineering Development Laboratory, Richland, Washington.

Hesson, G. M., and W. L. Thorne, 1957, Preliminary Experimental Results of Pressure and Temperature Response to Slow Plugging of a Process Tube, HW-49813, G.E. Hanford Company, Richland, Washington.

Hesson, G. M., and W. L. Thorne, 1957, Pressure, Flow, and Temperature Responses to a Rapid Plugging of a Process Tube, HW-48519, G.E. Hanford Company, Richland, Washington.

Hesson, G. M., and W. L. Thorne, 1957, Results of Experimental Tests Simulating Slow Plugging of a BDF Process Tube, HW-52424-B, G.E. Hanford Company, Richland, Washington.

Hesson, G. M., and W. L. Thorne, 1958, Results of Transient and Steady State Experiments Investigating Hazards of Flow Reductions in a $K$ Process Tube, HW-54329, G.E. Hanford Company, Richland, Washington.

Hesson, G. M., H. L. Thorne, and J. M. Batch, 1961, Surge Suppressor for the PRTR Process Flow Tube Meters, HW-70711, G.E. Hanford Company, Richland, Washington,

Hesson, G. M., D. E. Fitzsimmons, E. D. Waters, and J. M. Batch, 1962, Preliminary Boiling Burnout Experiments with a 19-Rod Bundle Geometry in Axial Flow, HW-73395, G.E. Hanford Company, Richland, Washington.

Hesson, G. M., W. L. Thorne, and J. M. Batch, 1963, Surge Suppressor for the PRTR Process Tube Meters, HW-70711, G.E. Hanford Company, Richland, Washington. 
Hesson, G. M., D. E. Fitzsimmons, and J. M. Batch, 1964, Boiling Burnout Experiments with Fog-Cooled Nineteen-Rod Bundle Test Sections, HW-80523, Rev. 1, G.E. Hanford Company, Richland, Washington.

Hesson, G. M., and D. E. Fitzsimmons, 1964, Comparison of Boiling Burnout Data for 19-Rod Bundles in Horizontal and Vertical Positions, HW-83443, G.E. Hanford Company, Richland, Hashington.

HEW, 1944, Hanford Technical Manual, Part B, HW-10475-B, Hanford Engineer Works, Richland, Washington.

HEW, 1945, History of Operations, 1 January 1944 to 20 March 1945, OUT-1462, Hanford Engineer Works, Richland, Washington.

Hewlett, R. G., and F. Duncan, 1972, Atomic Shie7d, U.S. Atomic Energy Commission, Washington, D.C.

Hewlett, R. G., and 0. E. Anderson, Jr., 1972, The New World, U.S. Atomic Energy Commission, Washington, D.C.

Hylbak, H. E., 1967, N-Reactor History, RL-GEN-1180, Sup. 1, G.E. Hanford Company, Richland, Washington.

Johnson, B. M., R. T. Allemann, D. W. Faletti, B. C. Fryer, and F. R. Zaloudek, 1976, Dry Cooling of Power Generating Stations: A Summary of the Economic Evaluation of Several Advanced Concepts via a Design Optimization Study and a Conceptual Design and Cost Estimate, BNWL-2120, Battelle Northwest Laboratories, Richland, Washington.

Johnson, B. M., F. R. Zaloudek, H. D. Fricke, R. G. Helenbrook, and J. A. Bartz, 1979, A Large-Scale Experimental Evaluation of an Advanced Concept for Dry/Wet Cooling of Power Stations, BN-SA-1064, Pacific Northwest Laboratory, Richland, Washington.

Johnson, P. A., 1952, Process Tube Purging During Pile Operation, HW-24602, G.E. Hanford Company, Richland, Washington.

Jordan, H. E., C. H. J. Wende, and P. F. Gast, 1945-1947, Month7y - 100 Area Technical Activity Reports - Physics - 10-25-45 through May 1947, HW-7-2984, Hanford Eng.ineer. Works, Richland, Washington.

Jordan, W. E., 1946, 100 Areas, January 1 through January 7, HW-7-3188, Hanford Engineer Works, Richland, Washington.

Jordan, W. E., 1946, 100 Areas, January 15 through January 21, HW-7-3307, Hanford Engineer Works, Richland, Washington.

Jordan, H. E., 1946, 100 Areas, January 29 through February 4, HW-7-3392, Hanford Engineer Works, Richland, Washington.

Jordan, W. E., 1946, 100 Areas, February 5 through February 11, HW-7-3441, Hanford Engineer Horks, Richland, Hashington. 
Kannberg, L. D., 1982, Underground Energy Storage Program, 1981 Annual Report, PNL-4281, Vols. I and II, Pacific Northwest Laboratory, Richland, Washington.

Kidder, C. P., 1946, CMX Final Report, HW-7-4444, Hanford Engineer Horks, Richland, Washington.

Koberg, D. R., and R. H. Purce11, 1962, Operation of the Plutonium Recycle Test Reactor, HW-SA-2556, G.E. Hanford Company, Richland, Washington.

Kratzer, H.: K., 1974, 1974 Thickness Measurement of $N$ Reactor Process Tube Connectors, UNI-70-E.2.a, United Nuclear Industries, Inc., Richland, Washington.

Kreid, D. K., J. M. Creer, J. M. Bates, M. S. Quigley, and A. M. Sutey, 1979, Fluid Flow Measurements in Rod Bundles Using Laser Doppler Anemometry Techniques, PNL-SA-7772, Pacific Northwest Laboratory, Richland, Washington.

Kruesi, F. E., G. E. Duval1, and D. E. Davenport, 1951, 100 Areas Technical Activities Report - Physics - November 1951, HW-22922, G.E. Hanford Company, Richland, Washington.

Kugler, A. N., 1968, Thermal Hydraulics Writeup Full-Length Mark IV Production Fuel Tests, DUN-8273, Douglas United Nuclear, Inc., Richland, Washington.

Lander, W. E. B., 1972, Possible Freezing Damage to Rupture Monitor Lines, DUN-8054, Douglas United Nuclear, Inc., Richland, Washington.

Lander, W. E. B., 1973, Marotta Va7ve PV34B Testing, DUN-8119, Douglas United Nuclear, Inc., Richland, Washington.

Lander, H. E. B., 1974, HCR Channel Renovation Test Procedure - Channel Liner Blocks, UNI-122, United Nuclear Industries, Inc., Richland, Washington.

Lander, W. E. B., 1974, HCR Channel Renovation Test Report - Channel Liner Blocks, UNI-122, Add. A, United Nuclear Industries, Inc., Richland, Washington.

Lattin, K. R., 1974, ATTN RTD Location and Hookup Confirmation, UNI-214, United Nuclear Industries, Inc., Richland, Washington.

Lattin, K. R., 1974, Development Test N-360: Water/Steam Spray Shield for Start-On RTDs, UNI-164, United Nuclear Industries, Inc., Richland, Hashington.

Lattin, K. R., 1985, Safety Study: Boiling Point Suppression and High Temperature Emergency Cooling System Instrumentation, UNI-3333, United Nuclear Industries, Inc., Richland, Washington.

Lechelt, J. A., 1984, Engineering Report: Process Tube Flow Monitor System, UNI-2925, United Nuclear Industries, Inc., Richland, Washington. 
Lee, P. J., 1986, Qualification Test Procedure, Process Tube Removal Jack, UNI-4193, United Nuclear Industries, Inc., Richland, Washington.

Lewis, M., 1952, Technical Activities Report, Pile Coolant Effects, June 1952, HW-24838, G.E. Hanford Company, Richland, Hashington.

Lewis, H. R., 1950, 100 Areas Technical Activities Report, Engineers, August 1950, HW-19068, G.E. Hanford Company, Richland, Washington.

Lewis, H. R., and R. A. Rohrbacher, 1953, Severe Pitting Attack of Pile Process Tubes and Slugs, HW-29132, G.E. Hanford Company, Richland, Washington.

Linscooten, C. G., 1986, Controlled Development Plan: Cutter - Incore Detector Assembly in the Graphite Cooling System, UNI-4148, United Nuclear Industries, Inc., Richland, Washington.

Long, J. H., 1969, Preliminary Resu7ts: Hydrodynamic Drag Coefficient Experiments with Various Obstructions Between Parallel Plates, DUN-6327, Douglas United Nuclear, Inc., Richland, Washington.

Lovington, R. C., 1955, Charge-Discharge During Pile Operation, HW-36224, G.E. Hanford Company, Richland, Washington.

Lyon, L. W., 1982, Evaluation of the Failed ECCS Primary Flush Line Piping Downstream of the V4-2 Valve, UNI-1986, United Nuclear Industries, Inc., Richland, Hashington.

Lyon, L. H., 1983, Status of the Tube Elongation Problem as of July, 1982, UNI-2110, United Nuclear Industries, Inc., Richland, Washington.

Martek, G. A., 1987, Control7ed Development P7an for Development/Fabrication of a Device for Characterization of Pressure Tube Inside Diameters, UNI-4263, United Nuclear Industries, Inc., Richland, Washington.

McCarthy, P. B., and F. W. VanWormer, 1956, Production Test No. 105-634-A: In-Pile Cocked Slug Tests, HW-43464, G.E. Hanford Company, Richland, Washington.

McCullough, J. D., 1969, Engineering Bases for Testing and Operating the $N$ Reactor Flow Monitor Transducer High Pressure Test Facility, DUN-5806, Douglas United Nuclear, Inc., Richland, Washington.

McEwen, L. H., J. M. Batch, D. J. Foley, and M. R. Kreiter, 1957, Heat Transfer "Beyond Burnout" for Forced Convection Bulk Boiling, HW-47892, G.E. Hanford Company, Richland, Washington.

McNutt, C. R., 1954, Summary of Data on Boiling Flow from the 189-D Tube Mock-Ups, HH-34150, G.E. Hanford Company, Richland, Washington.

McSweeney, T. I., H. L. Thorne, D. E. Fitzsimmons, and J. K. Anderson, 1978, Boiling Burnout in the Inner Annulus of the MK-IV Fuel Configuration Containing "W" Spring Supports, BNWL-CC-1811, Pacific Northwest Laboratory, Richland, Washington. 
Menegus, R. L., 1945, Procedure for Improving Temperature Distribution Via Rods and Columns - B Pile, HW-7-2744, Hanford Engineer Works, Richland, Washington.

Miller, N. R., 1953, Summary and Correlation of Water Quality Testing Results, HW-27393, G.E. Hanford Company, Richland, Washington.

Millhollen, M. K., and A. M. Sutey, 1970, PNL-17, EBR-II Instrumented Subassemb7y Test Interim Report, BNWL-1424, Battelle Northwest Laboratories, Richland, Washington.

Milton, W. H., 1946, Estimate of Life Manufacturing Piles, HW-3-6898, Hanford Engineer Works, Richland, Hashington.

Morris, W. J., 1955, Interim Report - Poison Splines Flexible Control System, HW-39792, G.E. Hanford Company, Richland, Washington.

Morris, W. J., 1956, Venturi Throat Diameter and Process Tube Connector Cavitation Analysis, CG-654, HW-44473, G.E. Hanford Company, Richland, Washington.

Ne1son, R. L., 1985, Engineering Test Report: Horizontal Control Rod Testing, UNI-3422, United Nuclear Industries, Inc., Richland, Washington.

Nelson, R. L., 1985, Procedure for Horizontal Control Rod Channel Distortion and Blockage Testing, UNI-3329, United Nuciear Industries, Inc., Richland, Washington.

Nelson, R. L., 1987, Acceptance Test Procedure: Expanding Mandrel for Tube Remova7, UNI-4191, Rev. 1, United Nuclear Industries, Inc., Richland, Washington.

Nelson, S. L., 1951, Memo on Process Water Refrigeration: A Current Evaluation, $100 \mathrm{~F}, \mathrm{D}$ and DR Areas, HW-21531, G.E. Hanford Company, Richland, Washington.

Newby, F. M., and R. P. Marsha11, Jr., 1983, Graphite Stack Inspection and Status Report, Calendar Year 1982, UNI-2109, United Nuclear Industries, Inc., Richland, Washington.

Newe11, G. A., 1969, Meeting on Proposed Modifications to the Variable Orifice Design, DUN-8266, Douglas United Nuclear, Inc., Richland, Washington.

Peters, H. R., and J. P. Schmidt, 1971, Second Interim Report: N Reactor Tube Scratching Investigation, DUN-7485, Douglas United Nuclear, Inc., Richland, Washington.

Pike, S. T., 1950, Letter to R. LeBaron, Chairman Military Liaison Committee, dated Aprit 5, 1950, U.S. Atomic Energy Commission, Washington, D.C.

Plum, R. L., 1973, Power Level History of Single-Pass Richl.and Reactors, PHM-542, U.S. Atomic Energy Commission, Richland, Washington. 
Pociluyko, M., 1965, Fuel Element Flow Distribution Test, RL-NRD-498, G.E. Hanford Company, Richland, Washington.

Pociluyko, M., 1972, Status Report - Production Test PT-NR-261: "Grayfoi7" Gasketing of V-11 and V-12 Valve Grayloc Joints as of February 14, 1972, DUN-7432-D, Douglas United Nuclear, Inc., Richland, Washington.

Pociluyko, M., 1973, Flow Test of Fuel Columns for Support of PT-N-344, UNI-81, United Nuclear Industries, Inc., Richland, Washington.

Pociluyko, M., 1973, Mark IA Fuel Flow Test, DUN-8157, Douglas United Nuclear, Inc., Richland, Washington.

Pociluyko, M., 1975, Production Test NR-402, UNI-466, United Nuclear Industries, Inc., Richland, Washington.

Pociluyko, M., 1979, Thermal Test of Graphite Boron Carbide Safety Balls at 1120 Degrees $F$ in Helium Atmosphere, UNI-1331, United Nuclear Industries, Inc., Richland, Washington.

Pociluyko, M., 1980, N Reactor Loop Component Test Facility Manual, UNI-M-87, United Nuclear Industries, Inc., Richland, Washington.

Pope, M. I., 1987, Acceptance Test Procedures for the Process Tube Drying System, UNI-4239, United Nuclear Industries, Inc., Richland, Washington.

Pound, D. C., 1957, Boilout Experiment, HW-48759, G.E. Hanford Company, Richland, Washington.

Pound, D. C., and G. J. Busselman, 1957, Process Tube Boilout Experiments, HW-52340, G.E. Hanford Company, Richland, Hashington.

Purce11, R. H., 1966, Plutonium Recycle Test Reactor Experience, 1962-1966, BNWL-SA-557, Battelle North West Laboratories, Richland, Washington.

Rainey, T. E., 1982, Engineering Study, Reactor Coolant System Control Valves, NPFR Project H-600, UNI-2182, United Nuclear Industries, Inc., Richl and, Washington.

Rasmussen, D. E., 1986, Reactor Survei77ance Equipment Evaluation, UNI-3583, United Nuclear Industries, Inc., Richland, Washington.

Reeves, J. A., 1983, Functional Design Criteria, 105-N Fuel Rupture Monitor Sample Water Reinjection System, project H-516, UNI-610, Rev. 1, United Nuclear Industries, Inc., Richland, Washington.

Reinker, P. H., 1951, Report on Additional Production Capacity of Hanford Works: Factors Involved in Case II and Case III, HW-22110, G.E. Hanford Company, Richland, Washington.

Reinker, P. H., and A. A. Johnson, 1949, 100 Areas Technical Activities Report - Engineering, October 1949, HW-15295, G.E. Hanford Company, Richland, Washington. 
Reinker, P. H., and A. A. Johnson, 1950, 100 Areas Technical Activities Report - Engineering, December 1949, HW-15715, G.E. Hanford Company, Richland, Washington.

Richmond, W. D., and C. W. Pollock, 1968, Corrosion and Hear Surveillance in Plutonium Recycle Test Reactor Through December 1967, BNWL-726, Battelle Northwest Laboratories, Richland, Washington.

Riggs, L. R., 1951, P-11 Laboratory Fire Investigation, December 4, 1951, HH-22936, G.E. Hanford Company, Richland, Washington.

Robb, J. E., 1953, Process Test MR-105-15: Production Increases by the Use of Venturi Orifices, HW-28784, G.E. Hanford Company, Richland, Washington.

Robinson, R. K., 1970, Process Development Accomplishments, Douglas United Nuclear, Inc., DUN-7066, Douglas United Nuclear, Inc., Richland, Washington.

Robinson, R. K., 1970, ZTM Limits for 5-Cell Operation, DUN-8241, Douglas United Nuclear, Inc., Richland, Washington.

Rowe, D. S., J. K. Anderson, and W. L. Thorne, 1964, Transient ThermalHydrauTic Experiments -- N-Reactor Inlet Connector Break, HW-84104, G.E. Hanford Company, Richland, Washington.

Rowe, D. S., C. L. Wheeler, and D. E. Fitzsimmons, 1973, An Experimental Study of Flow and Pressure in Rod Bundle Subchannels Containing Blockages, BNWL-1771, Battelle Northwest Laboratories, Richland, Washington.

Rudock, E. R., 1955, Evaluation of Teflon Hose, HW-37090, Rev. 1, G.E. Hanford Company, Richland, Washington.

Russe11, A., 1973, Production Test N-349: Measurement of Process Tube Elongation Forces, UNI-104, United Nuclear Industries, Inc., Richland, Washington.

Schilson, R. E., 1951, Pile Technology Test Report - Flapper Nozzle Assembly, HW-23086, G.E. hanford Company, Richland, Washington.

Schmidt, J. P., 1970, Technology Section Position - N Reactor Design Criteria, Process Tube Fuel Spacers, DUN-8244, Douglas United Nuclear, Inc., Richland, Washington.

Scott, K. V., 1982, N-Reactor Pressure Tube Curvature Effects, UNI-1960, United Nuclear Industries, Inc., Richland, Washington.

Shaw, C. P., 1974, Development Test DT-N-372: V-12 Vibrators, UNI-279, United Nuclear Industries, Inc., Richland, Washington.

Shoemaker, R. H., 1965, Thermal Hydraulics Parameters - CoProduct Fue7, DUN-8264, UNI-3452, G.E. Hanford Company, Richland, Washington. 
Shoemaker, R. H., 1968, Laboratory Test Results - 12 inch Mark IC Fuel with Spring-Stop Support System, DUN-8267, Douglas United Nuclear, Inc., Richland, Washington.

Shoemaker, R. H., 1968, ZTM Protection for Mark IV Fue1, DUN-8242, Douglas United Nuclear, Inc., Richland, Washington.

Shoemaker, R. H., 1972, Technical Criteria, N Reactor Safety Flow Leg Modifications Back Flow Test Requirements, DUN-7073, Sup. 2, Douglas United Nuclear, Inc., Richland, Washington.

Shoemaker, R. H., and E. L. Etheridge, 1978, Preliminary Draft - Technical Requirements for Plant Improvements Identified by the NUSAR Program, UNI-906-RD1, Add. 2, United Nuclear Industries, Inc., Richland, Washington.

Shoemaker, R. H., R. E. and Fuller, 1982, Thermal Hydraulic Bases for Four-Cell Operation, UNI-2016, United Nuclear Industries, Inc., Richland, Washington.

Simon, W. 0., and M. H. Smith, 1945, Pile Power Leve7, HW-7-1948, Hanford Engineer Works, Richland, Washington.

Simsen, C. A., 1973, Investigation of Malfunction: No. 2 Exhaust Confinement Valve, Unusual 0ccurrence 73-6, UNI-23, United Nuclear Industries, Inc., Richland, Washington.

Sinclair, M., 1968, "Battelle-Northwest - I.R. Laboratory of the Year," Industrial Research, Vo1. 10, No. 5, Ann Arbor, Michigan.

Sivula, C., and D. Whitney, 1988, "Cold Standby for N," Tri-City Herald, February 17, pp. Al-2, citing Michael Lawrence, Kennewick, Washington.

Smith, C. M., 1987, Test Report of QTP UNI-4047, Testing the VOTAW and Original V-11 Vanes, UNI-4253, United Nuclear Industries, Inc., Richland, Washington.

Smith, M. H., and H. Worthington, 1945, Production Test No. 105-28-P: Determination of Possibility of Film Removal by Increased Water Flow, HW-3-2074, Hanford Engineer Works, Richland, Washington.

Solecki, J. E., 1970, N-Reactor Fuel Flushing Test, DUN-6606, Douglas United Nuclear, Inc., Richland, Washington.

Stauch, D. J., 1986, Controlled Development Plan for Graphite Cooling Tube Surveillance and Removal, UNI-4210, United Nuclear Industries, Inc., Richland, Washington.

Stewart, C. H., M. C. C. Bampton, D. T. Aase, and A. M. Sutey, 1978, The Limits of Helium Cooling in Fusion Reactor First Walls and Blankets, PNL-2477, Pacific Northwest Laboratory, Richland, Washington. 
Stickney, R. R., 1969, Production Test PT-NR-131" Rupture Honitor Flow Determination, DUN-6368, Douglas United Nuclear, Inc., Richland, Washington.

Strege, D. E., 1954, Interim Report, Production Test 105-522-E, Examination of Pile Process Tubes Removed from 100-B, C and D Piles, HH-32960, G.E. Hanford Company, Richland, Washington.

Sullivan, J. L., 1986, $N$ Reactor Production Test and Development Test Status Report, UNI-4225, United Nuclear Industries, Inc., Richland, Washington.

Sutey, A. M., 1967, A Method to Simulate Interchannel Flow Through Fuel Element Junctions During Laboratory Tests on a C-Reactor Fuel Model, BNWL-CC-1369, Battelle Northwest Laboratories, Richland, Washington.

Sutey, A. M., and J. G. Knudsen, 1968, Mass Transfer at the Solid-Liquid Interface for Climbing Film Flow in an Annular Duct, BNWL-SA-1767, Battelle Northwest Laboratories, Richland, Washington.

Sutey, A. M., 1968, Mixer Spool Effectiveness and Pressure Loss Evaluations for Low Pressure Reactors, BNWL-CC-1534, Battelle Northwest Laboratories, Richland, Washington.

Sutey, A. M., A. M. Fitzsimmons, and C. W. Angle, 1970, Steady State Thermal Hydraulic Characteristics of One-Inch Overbore Fuel, BNWL-CC-2581, Battelle Northwest Laboratories, Richland, Washington.

Sutey, A. M., D. E. Fitzsimmons, W. L. Thorne, and L. B. Torobin, 1971, Critical Heat Flux \& Two Phase Hydraulic Investigation of a 16-Rod Simulation of a BWR Fuel Assemb7y, BNWL-SA-3724, Battelle Northwest Laboratories, Richland, Washington.

Sutey, A. M., 1971, Preliminary Results of the Loss-of-Coolant Heat Transfer Study for $N$ Reactor, BNWL-B-88, Battelle Northwest Laboratories, Rich Tand, Washington.

Sutey, A. M., and D. S. Rowe, 1972, A Review of the Effect of Housing Temperature on FLECHT Heat Transfer Results, BNWL-B-189, Battelle Northwest Laboratories, Richland, Washington.

Sutey, A. M., and D. S. Rowe, 1972, Analysis of Core Flow Distribution During Downflow Period of a LOCA, BNWL-B-188, Battelle Northwest Laboratories, Richland, Washington.

Sutey, A. M., and D. S. Rowe, 1972, Analysis of the Effect of Uniform Core Blockage on PWR Core Flow During Reflood, BNWL-B-187, Battelle Northwest Laboratories, Richland, Washington.

Sutey, A. M., and C. W. Stewart, 1973, A Thermal Hydraulic Analysis of the Pacific Northwest laboratory Fusion-Fission Hybrid Reactor Concept, BNWL-B-283, Battelle Northwest Laboratories, Richland, Washington. 
Sutey, A. M., F. R. Zaloudek, and H. J. Bomelburg, 1977, Requirements for a Helium-Cooled Blanket Heat Removal System Development Facility for Fusion Reactor Research, BNWL-2301, Pacific Northwest Laboratory, Richland, Washington.

Takasumi, D. S., 1979, Functional Design Criteria: Seismic Resistance Improvements to Fog Spray System, Project H-522, UNI-725, Rev. 2, United Nuclear Industries, Inc., Richland, Washington.

Taylor, A. T., 1954, Status Report: Aluminum Process Tube Development, HW-34229, G.E. Hanford Company, Richland, Washington.

Telford, P. K., 1967, Proposed HCR Cooling System Improvements, RL-GEN-1542, G.E. Hanford Company, Richland, Hashington.

Thorne, W. L., 1968, Batte7le Northwest Thermal Hydraulics Laboratory, BNWL-SA-1770, Battelle Northwest Laboratories, Richland, Washington.

Toyoda, K. G., and J. F. Calkin, 1957, Results of Experimental Tests Simulating Supply Pressure Decrease in a K Process Tube, HW-53593, G.E. Hanford Company, Richland, Hashington.

Toyoda, K. G., 1961, Description of Transient System, High Pressure Heat Transfer Apparatus - 189D, HW-71389, G.E. Hanford Company, Richland, Washington.

Tri-City Herald, 1964, "Hanford To Cut Back in 1965," Tri-City Hera7d, January 8, 1964, p. 1, Kennewick, Washington.

Trimble, D. J., 1977, Evaluation of V4-3 Valve Body Defects, UNI-854, United Nuclear Industries, Inc., Richland, Washington.

Trumble, R. E., 1956, Hazards Summary Report - Projects CG-6558 and CG-600 Reactor Plant Modifications, Volume I, HW-44708, Vol. II, G.E. Hanford Company, Richland, Washington.

Trumble, R. E., 1957, Hazards Summary Report - Projects CG-6558 and CG-600 Reactor Plant Hodifications, Volume I, HW-44708, Vol. I, G.E. Hanford Company, Richland, Washington.

Vanderwater, R. G., 1952, Boiling Limits, HW-23251, G.E. Hanford Company, Richland, Washington.

Vanderwater, R. G., 1952, Tube Temperature Rise Limits - Boiling Considerations, HW-23861, G.E. Hanford Company, Richland, Washington.

VanWormer, F. W., 1958, Flow Protection Limits, Operational Charge-Discharge Facility - C Reactor, HW-64415, G.E. Hanford Company, Richland, Washington.

Walker, R. L., 1987, Procurement Specification for 189-D Electrical Substation, UNI-4214, Rev. 1, United Nuclear Industries, Inc., Richland, Washington. 
Waters, E. D., 1956, Approximate Hethod of Correlating Panellit Pressure with Front Header Pressure at the Critical Flow Point in Reactor Orifice Assemblies, HH-47197, G.E. Hanford Company, Richland, Washington.

Waters, E. D., 1958, Laboratory Pressure Drop Data For Support Charges Using Pierced-Solid Dummy Slugs - A7l Reactors, HW-55269, G.E. Hanford Company, Richland, Washington.

Haters, E. D. and G. R. Horn, 1958, Standard Laboratory Hydraulic Pressure Drop Characteristics of Various Solid and I\&E Fuel Elements, HW-54590, G.E. Hanford Company, Richland, Washington.

Waters, E. D., and D. E. Fitzsimmons, 1960, Laboratory Data for Review of Out let Water Temperature Limits for BDF Type Reactors, HW-67139, G.E. Hanford Company, Richland, Washington.

Waters, E. D., 1960, Laboratory Determination of Normal Operating Flow Rates with Enlarged Outlet. Fittings - BDF Reactors, HW-63756-1, G.E. Hanford Company, Richland, Washington.

Waters, E. D., J. K. Anderson, W. L. Thorne, and J. M. Batch, 1962, Experimental Observations of Upstream Boiling Burnout, HW-73902, G.E. Hanford Company, Richland, Washington.

Waters, E. D., 1962, Flow Tests of Enlarged Outlet Fittings - BDF Reactors, HW-63756-4, G.E. Hanford Company, Richland, Washington.

Waters, E. D., G. M. Hesson, D. E. Fitzsimmons, and J. M. Batch, 1963, Boiling Burnout Experiments with 19-Rod Bundles in Axial Flow, HW-77303, G.E. Hanford Company, Richland, Washington.

Waters, E. D., and D. E. Fitzsimmons, 1963, DNB Varies With Spacing in 19-Rod Bundles, HW-SA-3086, G.E. Hanford Company, Richland, Washington.

Weed, L. S., 1975, Final Report: Production Test N-385: A Procedure for Establishing Low Once-Through Coolant Flow During Major Reactor Component Maintenance, UNI-373-B, United Nuclear Industries, Inc., Richland, Washington.

Weed, L. S., 1975, Production Test N-394: Special Flow Arrangement for V-4 Valve Repair, UNI-438, United Nuclear Industries, Inc., Richland, Washington.

Weed, L. S., and E. L. Etheridge, 1977, Production Test N-399: Special Flow Arrangement for $V-12$ Replacement and Inspection and Repair of Primary Loop Components, UNI-462, United Nuclear Industries, Inc., Richland, Hashington.

Hegener, E. A., 1969, Flow Monitoring Sensing Line Replacement Advisory Representatives Meeting Number Three, DUN-6507-RD, Douglas United Nuclear, Inc., Richland, Washington. 
Hende, C. H. J., 1945-1946, 100 Technical - Miscellaneous Physics Activities, covers periods 8-25-45 to Apri7 25, 1946, HW-7-2520-DEL, Hanford Engineer Horks, Richland, Hashington.

Wende, C. H. J., 1946, Final Report: Production Test No. 305-9-P: Poisoning Effectiveness and Uniformity of Myrnalloy Slugs, HW-7-3486, Hanford Engineer Works, Richland, Washington.

Wende, C. W. J., 1946, Production Test No. 305-9-P: Poisoning Effectiveness and Uniformity of Myrnalloy Slugs, HW-7-3486, Hanford Engineer Works, Richland, Washington.

Wende, C. H. J., 1947, Hanford Engineer Horks Technical Progress letter No. 152, HW-7-6311, G.E. Hanford Company, Richland, Washington.

Wende, C. H. J., 1949, Pile Operation at Higher Power, HW-13184, G.E. Hanford Company, Richland, Washington.

Wheeler, C. L., C. W. Stewart, R. J. Cena, D. S. Rowe, and A. M. Sutey, 1976, COBRA-IV-I: An Interim Version of COBRA for Therma7-Hydraulic Analysis of Rod Bund7e Nuclear Fuel Elements and Cores, BNWL-1962, Battelle Northwest Laboratories, Richland, Washington.

Wilson, C. D., 1953, Flow Laboratory Investigation of "F-Type" Pitting of Siugs and Tubes, HW-28207, G.E. Hanford Company, RichTand, Washington.

Windsheimer, W. W., 1951, Pile Level Objectives, HH-20841, G.E. Hanford Company, Richland, Washington.

Wittekind, H. D., and H. Toffer, 1979, U1trasonic Flowmeters: An Interim Progress Report, UNI-1318, United Nuclear Industries, Inc., Richland, Washington.

Holkenhauer, W. C., B. R. Leonard, Jr., A. M. Sutey, and R. W. Moir, 1974, Conceptual Design of a Fusion-Fission Hybrid Reactor Based on Mirror Fusion Reactor With a Subcritical Gas Cooled Fission Blanket, BNWL-SA-4865, Battelle North West Laboratories, Richland, Washington.

Wood, J. C., 1952, Interim Report \#2, Test Project \#29, "C" and "D" Machines Functional and Life Tests, HW-23955, G.E. Hanford Company, Richland, Washington.

Hoods, W. K., 1947, 100 Areas Technical Activities Report - Engineering, Apri7 1947, HW-7-6254, G.E. Hanford Company, Richland, Washington.

Woods. W. K., 1947, 100 Areas Technical Activities Report - Engineering, June 1947, HW-07178, G.E. Hanford Company, Richland, Washington.

Woods, W. K., 1947, 100 Areas Technical Activities Report - Engineering, JuTy 1947, HW-07431, G.E. Hanford Company, Richland, Washington.

Woods, W. K., 1947, 100 Areas Technical Activities Report - Engineering, August 1947, HW-07597, G.E. Hanford Company, Richland, Washington. 
Woods, W. K., 1947, 100 Areas Technical Activities Report - Engineering, September 1947, HW-07827, G.E. Hanford Company, Richland, Washington.

Hoods, W. K., 1948, 100 Areas Technical Activities Report - Engineering, November 1947, HW-08491, G.E. Hanford Company, Richland, Washington.

Hoods, W. K., 1948, 100 Areas Technical Activities Report - Engineering, January 1948, HW-09005, G.E. Hanford Company, Richland, Washington.

Hoods, W. K., 1948, 100 Areas Technical Activities Report - Engineering, February 1948, HW-09314, G.E. Hanford Company, Richland, Washington.

Hoods, W. K., 1948, 100 Areas Technical Activities Report - Engineering, April 1948, HW-09955, G.E. Hanford Company, Richland, Washington.

Hoods, H. K., 1948, 100 Areas Technical Activities Report - Engineering, May 1948, HW-10160, G.E. Hanford Company, Richland, Washington.

Woods, W. K., 1948, 100 Areas Technical Activities Report - Engineering, June 1948, HW-10548, G.E. Hanford Company, Richland, Washington.

Woods, H. K., 1948, 100 Areas Technical Activities Report - Engineering, March 1949, HW-13007, G.E. Hanford Company, Richland, Washington.

Hoods, H. K., 1950, Limits of Pi7e Operating Leve7, HW-19721, G.E. Hanford Company, Richland, Washington.

Horthington, H., 1945, Consequences of High Power Leve7s, HW-7-1936, Hanford Engineer Works, Richland, Washington.

Yatabe, J. M., R. E. Collingham, J. R. Hi7l, and W. L. Thorne, 1969, First FFTF Local Clad Temperature Tests with 7-Pin Bund7es, BNWL-SA-2577, Battelle Northwest Laboratories, Richland, Washington.

Yatabe, J. M., R. E. Collingham, V. R. Hill, T. I. McSweeney, and W. L. Thorne, 1970, Fast Reactor Fuel Assemb7y Thermal Hydraulic Development Program - Sodium Heat Transfer, BNWL-1136, Batte17e Northwest Laboratories, Richland, Washington.

Zaloudek, F. R., 1961, The Low Pressure Critical Flow Behavior of Steam-Water Mixtures in Constant Area Flow Passages, HW-68934, G.E. Hanford Company, Richland, Washington.

Zaloudek, F. R., and G. M. Hesson, 1963, Calculations of the Surface Heat Flux and Fuel Temperatures for PRTR MK-I PuO $\mathrm{OUO}_{2}$ Fuel Element with Segregated $\mathrm{PuO}_{2}$, HW-76115, G.E. Hanford Company, Richland, Washington.

ZaToudek, F. R., 1963, Notes on Heat Transfer from Rotating Machinery Components, HW-79463-RD, G.E. Hanford Company, Richland, Washington.

Zaloudek, F. R., 1963, The Critical Flow of Hot Water Through Short Tubes, HW-77594, G.E. Hanford Company, Richland, Washington. 
Zaloudek, F. R., 1964, Contribution to Report 'Critical Flow Phenomena in Two-Phase Mixtures and Their Relationships to Reactor Safety, HW-SA-3340, G.E. Hanford Company, Richland, Washington.

Zaloudek, F. R., 1964, Steam-Water Critical Flow from High Pressure Systems Interim Report, HW-80535-RD, G.E. Hanford Company, Richland, Washington.

Zaloudek, F. R., 1965, The Low Pressure Critical Discharge of Steam-Water Mixtures from Pipe Elbows and Tees, BNWL-34, Battelle Northwest Laboratories, Richland, Washington.

Zaloudek, F. R., and R. H. Moulton, 1969, Program Description: Critical Flow of Reactor Coolants Through Nozzles, BNWL-CC-1989, Battelle Northwest Laboratories, Richland, Hashington.

Zaloudek, F. R., and B. M. Johnson, 1974, Dry Cooling Tower Program: Results of Industrial Contacts Through August 1974, BNWL-1878, Battelle Northwest Laboratories, Richland, Hashington.

Zaloudek, F. R., R. T. Allemann, D. W. Faletti, B. M. Johnson, H. L. Parry, G. C. Smith, R. D. Tokarz, and R. A. Walter, 1976, A Study of the Comparative Costs of Five Wet/Dry Cooling Tower Concepts, BNWL-2122, Battelle Northwest Laboratories, Richland, Washington.

ZaToudek, F. R., and E. S. Ruff, 1986, Pressure Tube Testing Test P7an Document Production Assurance Program, UNI-3653, (PNL-5924), United Nuclear Industries, Richland, Hashington.

Zaloudek, F. R., and E. S. Ruff, 1986, Zirconium Pressure Tube Testing, Test Procedures Production Assurance Program (Project H-700), UNI-3994, (PNL-5930), United Nuclear Industries, Richland, Washington. 
WHC-MR-0465

This page intentionally left blank. 


\section{DISTRIBUTION}

Number of Copies

OFFSITE

1

City of Richland

Richland City Hall

505 Swift Blvd.

Richland, Washington 99352

J. C. King, Manager

1

National Academy of Sciences

2101 Constitution Ave.

Washington, DC 20418

R. Andrews

1

Oregon Department of Energy

625 Marion St. NE

Salem, Oregon 97310

D. Dunning

1

Washington State Historical Society

315 N. Stadium Way

Tacoma, Washington 98403

D. L. Nicandri, Director

\section{ONSITE}

7

U.S. Department of Energy, Richland Operations Office
J. K. Erickson
A5-19
R. D. Freeberg
A5-19
E. D. Goller
A5-19
A. C. McKarns
A5-52
N. A. Herdel
D. M. Weissberg
A5- 19
DOE-RL Public Reading Room
A5-19
A1-65

5

Bechtel Hanford, Inc.

M. C. Hughes

$\times 5-55$

M. A. Mihalic

$\times 5-53$

M. R. Morton

H4 -79

S. D. Thoren

$\times 5-53$

R. S. Weeks

H6-02 
WHC-MR-0465

DISTRIBUTION (cont.)

Number of Copies

ONSITE

2

Pacific Northwest Laboratory

P. M. Eick P8-55

Hanford Technical Library P8-55

1

U.S. Environmental Protection Agency

L. E. Gadbois

B5-01

1

Washington Department of Ecology

D. L. Patenshus

N1-05

180

Westinghouse Hanford Company

M. V. Berriochoa

B3-30

R. J. Bliss

R3-50

D. B. Cartmell

R3-56

M. C. Druby

B3-30

F. G. Fetterolf

L4-16

J. C. Fulton

E. W. Gerber

R3-85

M. S. Gerber (157)

R3-86

$\mathrm{N} 1-36$

D. G. Hamrick

S6-15

H. W. Heacock

S7-81

C. S. Krogness

L8-09

W. J. McKenna

B3-30

J. C. Midgett

N2-51

L. F. Perkins, Jr.

S6-15

P. M. Phelps

B3-30

W. J. Sanderson

B3-35

J. M. Steffen

J. E. Truax

N1-47

P. K. Vacca

E. C. Vogt

$\times 3-71$

Central Files

T5-50

Information Release

Administration

(3)

L8-04

L8-07 